\title{
CHILDREN IN COLONIAL AMERICA
}

by

Lori J. Breyer

A Thesis

Presented to

The Faculty of Humboldt State University

In Partial Fulfillment

of the Requirements for the Degree

Master of Arts

Social Science

Emphasis: Teaching American History

May 2006 


\section{CHILDREN IN COLONIAL AMERICA}

\section{A HISTORIOGRAPHY}

by

Lori J. Breyer

Approved by the Master's Thesis Committee:

Delores McBroome, Major Professor

Date

Gayle Olson-Raymer, Committee Member

Date

Rodney Sievers, Committee Member

Date

Delores McBroome, Graduate Coordinator

MASS - Teaching American History Cohort

Date

Donna E. Schafer, Dean for Research and Graduate Studies

Date 


\begin{abstract}
This project summarizes the historical perspectives on childhood in Colonial America. The historiography includes discussions of home life, school life, discipline, manners, religious thought, clothing, and games, all examined within the context of a geographical comparison.

The major theme is that children's behavior varied by geography in the colonial era. Religious beliefs, economics and immigration patterns shaped the culture of the region.

This project includes a lesson plan that is focused on children's activities in the colonial era including daily diary entries.
\end{abstract}




\section{ACKNOWLEDGEMENTS}

I am grateful for the encouragement and editing suggestions from Professor Gayle

Olson-Raymer. Without her constant push for this thesis to be better, my output would have been mediocre at best. I am also thankful to Professor Dee McBroome for seeing the sparkle in my eye when I described with excitement the topic for this thesis during a trip to the East Coast.

To my kids, Megan and Katie, for missing out on a lot of fun trips we normally do together on weekends and school breaks while their Mom sat in front of the laptop or with a nose in her book. I promise life will return to normal shortly. To my parents, thank you for the endless babysitting and support. And finally, a huge thank you to my husband and best friend, Dave who kept the kids busy, did many of the household chores I totally ignored and who motivated me to do the best I could. I could not have done this without you by my side! 


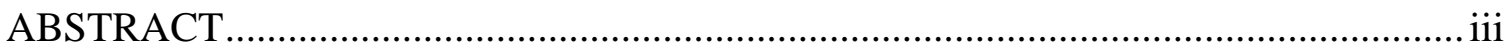

ACKNOWLEDGEMENTS ........................................................................................ iv

TABLE OF CONTENTS.................................................................................

LIST OF TABLES ................................................................................................ vii

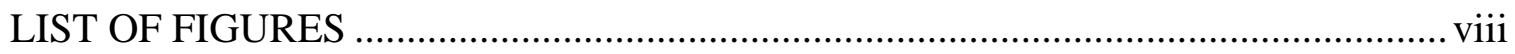

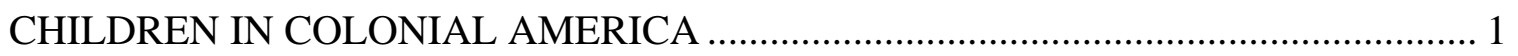

Childhood in New England Colonies ........................................................................ 2

Childhood in the Middle Colonies ...................................................................... 14

Childhood in the Southern Colonies.................................................................... 17

Summary: Regional Comparisons of Colonial Youth ..................................................... 22

INTRODUCTION TO LESSON PLANS ………………......................................... 26

Prior Content Knowledge and Skills............................................................................ 28

Discussion of Content Hook and Theme ................................................................ 28

LESSON CONTENT ...................................................................................... 29

APPENDIX A CALIFORNIA STANDARDS ADDRESSED ......................................... 45

APPENDIX B COLONIAL GEOGRAPHY (DAY ONE) ………………………........ 48

APPENDIX C COLONIAL HOUSING (DAY TWO) ……………………………..... 59

APPENDIX D COLONIAL CLOTHING (DAY THREE) ............................................. 64

APPENDIX E COLONIAL GAMES (DAY FOUR) …………………....................... 70

APPENDIX F COLONIAL WORK - TODDLERS TO AGE SEVEN (DAY FIVE) ... 78

APPENDIX G COLONIAL WORK -AGE SEVEN TO ADULT (DAY SIX) .............. 81

APPENDIX H COLONIAL SCHOOL (DAY SEVEN) ……………………………....... 88 
APPENDIX I COLONIAL CHURCH (DAY EIGHT) ............................................... 91

APPENDIX J COLONIAL CONCLUSION \& COMPARISON (DAY TEN)............. 106

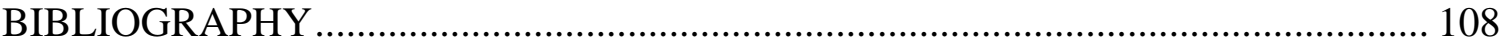




\section{LIST OF TABLES}

Table Page

1 Colonial Demographics................................................57

2 Population Comparisons in the Colonies...................................60 


\section{LIST OF FIGURES}

$\begin{array}{lll}\text { Figure } & \text { Page }\end{array}$

1 Blank map of Colonial America........................................46

2 Map of Colonial America by regions.................................... 47

3 Colonial Immigrations pattern map....................................48 


\section{CHILDREN IN COLONIAL AMERICA}

“... the easiest way of becoming acquainted with the modes of thinking, the rules of conduct, and the prevailing manners of any people, is to examine what sort of education they give their children; how they treat them at home, and what they are taught in their places of public worship.” ... J. Hector St. John de Crevecour ${ }^{1}$

In viewing life in Colonial America, historians have relied on information gathered and interpreted from both a demographic approach that includes parish records, vital records, wills, and deeds as well as a sociological approach that includes primarily letters, diaries, memoirs, and autobiographies. From these records, historians have analyzed colonial youth in terms of their physical setting, family and community structure, socialization and training, religion and work experience in Colonial America. ${ }^{2}$ These historical aspects of colonial youth provide rich avenues for comparisons and contrasts when examined within each of the three geographical regions of Colonial America: New England Colonies, Middle Colonies, and Southern Colonies.

\footnotetext{
${ }^{1}$ J. Hector St. John de Crèvecoeur, Letters from an American Farmer (London: Everyman, n.d.), p. 113 as cited in James L. Axtell, The School Upon a Hill (New Haven and London: Yale University Press, 1974), xii.

${ }^{2}$ For purposes of this paper, it will be assumed that the word youth includes the ages from birth to marriage. Due to the lack of documention, partly resulting from a lower level of literacy, there is very little primary source information on poor youth in Colonial America. What little historians have written about children of the lower economic strata has been included in this paper.
} 


\section{Childhood in New England Colonies}

"Anyone who studies a part of New England history long enough and hard enough to write a book about it is likely to generalize from what he finds.” ... Edmund S. Morgan ${ }^{3}$

In general, English immigrants populated New England and upon so doing, set out to do things differently than in the Old Country. The population of this region was the most homogeneous of all of the regions due to the commonality of their faith. Therefore, the study of the youth as a whole in this region is simplified due to the similarities.

Historians who examined the physical setting of colonial families living in Massachusetts, New Hampshire, Rhode Island and Connecticut focused primarily on the home, church, and community environment of the adult which, in turn, shaped the lives of the children of colonial New England. To understand the lives of its children, it is necessary to examine what historians know about the physical environments of the colonial homes and churches, as well as the physical and social make-up of the New England communities.

John Demos’ comprehensive analysis of Plymouth Colony found that the typical colonial home began as a one story shelter and progressively grew to one-and-a-half stories. ${ }^{4}$ While houses were originally made of twigs and clay, a sturdier solid frame and clapboard structure eventually replaced this early structure. Cloth or oiled paper

\footnotetext{
${ }^{3}$ Edmund S. Morgan, The Historians of Early New England, as printed in The Reinterpretation of Early American History: Essays in honor of John Edwin Pomfret, Edited by Ray Allen Billington (San Marino, CA: The Huntington Library, 1966), p. 59-60.

${ }^{4}$ John Demos, A Little Commonwealth: Family Life in Plymouth Colony (New York: Oxford University Press, 1970), 39.
} 
windows were replaced by leaded glass in the last half of the seventeenth century. The "hall” was the main room for the kitchen, dining and family activities. In many houses, this one room also functioned as the bedroom, with bedding moved aside during the day. A larger house might include a second room for sleeping. Consequently, little personal privacy for either adults or children existed in the colonial homes of New England.

Because of the small size of the house, the furnishings were very limited. An average house had a dining table with a bench. In many families, the children stood while the adults sat and ate their meal. Any other tables or chairs were rare. Boxes and chests served a double purpose of storage and seating or table space. Bed frames were most often made of wood with cord laced to form what we now consider a box spring. Mattresses were made of anything from “flock” (stuffed with rags, wool, etc.) or feathers (a true sign of wealth). According to Alice Morse Earle, feathers were not advised for children as it was felt they needed a hard bed to develop their character. ${ }^{5}$

Demos notes that cooking utensils were very important and were often listed in wills and dowries as were table linens and napkins ${ }^{6}$. The most essential item was the spoon, knives were rare and forks were nonexistent. Plates were made of earthenware, pewter or wood. Other containers might be made of glass.

Church buildings had even less creature comforts than the home. Axtell notes that it was often "rudely constructed, crowded, dark, drafty, and unheated"7 . This is especially important considering that church attendance totaled up to 10 hours each week.

\footnotetext{
${ }^{5}$ Alice Morse Earle, Child Life in Colonial Days (Stockbridge: Berkshire House Publishers, 1899), 26.

${ }^{6}$ Demos, 42.

${ }^{7}$ James Axtell, The School Upon a Hill (New Haven and London: Yale University Press, 1974), 7.
} 
Daniel Smith claims New England families were tight-knit, patriarchal, religious, and had a strong sense of community. ${ }^{8}$ The sparse native population, largely the result of a previous decimation by diseases brought from European fisherman, left vast amounts of land to be organized as the settlers wished. According to Taylor, a new town could be started with a minimum of twenty families and a minister. ${ }^{9}$ The town was the center of the community with houses built next to each other and land dispersed out from the town radius in pie shaped pieces. Bushman describes a typical land plot as a strip one hundred to one thousand feet wide by two to three miles long. ${ }^{10}$ In the beginning, this created a huge sense of community with the grouping of homes so close. Farmers concentrated their planting on the land closest to their homes since this was the first land cleared of trees. However, as Bushman and Axtell state, once the land farther out of town was cleared and ready for farming, it became harder for many farmers to live in town ${ }^{11}$. Summer homes were built to live in closer to the bulk of the land and the farmers would come in to town only for Sunday services and winter.

Axtell found that the early sense of community created a self regulating environment. ${ }^{12}$ The community, Cable states, was responsible for building houses, not

\footnotetext{
${ }^{8}$ Daniel Blake Smith, "The Study of the Family in Early America: Trends, Problems, and Prospects” The William and Mary Quarterly, $3^{\text {rd }}$ Ser., Vol. 39, No. 1, The Family in Early American History and Culture (Jan. 1982): 17.

${ }^{9}$ Dale Taylor, The Writer's Guide to Everyday Life in Colonial America: From 1607-1783 (Cincinnati: Writer's Digest Books, 1997), 40.

${ }^{10}$ Richard L. Bushman, From Puritan to Yankee: Character and the Social Order in Connecticut, 16901765 ( Cambridge, MA: Harvard University Press 1967), 54.

${ }^{11}$ Bushman, 54.

${ }^{12}$ Axtell,139.
} 
individuals. Farmers would help each other plow and harvest; women would share in household duties such as quilting and candle making. ${ }^{13}$

Socialization in New England was very tight-knit and neighborly within the community. Northern Colonists however, were quite cold to strangers. According to historian Mary Cable, “A stranger walking down the main street of a New England village - even of Boston as late as 1714 - was formally 'warned out' by the sheriff or tithingman... the reason was a fear that the community might become responsible for them; or that they might spread an epidemic.”14 Axtell goes further, stating that New Englanders were warned not to take in boarders and if they did, the boarders were to attend family worship services as well as be governed by the family with whom they lived. ${ }^{15}$ Life in the Northern Colonies clearly centered around the family and the control over family behavior.

The individual family group was the center of life for colonial New England families. Some historians refer to the popularity of extended families. Smith's analysis of census records found that the nuclear family was much more the norm. ${ }^{16}$ Having Grandparents, Aunts, Uncles and cousins in the same household was not typical according to the written census records. Some writings on this period also refer to the prevalence of large families. Mintz states that the average family was seven to nine children while Greven’s more localized Andover, Massachusetts population study states

\footnotetext{
${ }^{13}$ Mary Cable, American Manners and Moral. (New York: American Heritage Publishing Co., Inc., 1969), 31.

${ }^{14}$ Mary Cable, American Manners and Morals, 31.

${ }^{15}$ Axtell, p. 121.

${ }^{16}$ Smith, 10.
} 
the average was over eight children per family. ${ }^{17}$ However, other writings by historians Demos and Smith have found that only about a third of the families were larger than six. $^{18}$

These physical environments of the home and the church, as well as the physical and social foundations of community and family had a great deal of influence for the lives of colonial children in New England. Children began life in a very nurturing environment. As Demos states, their first year of life was a "relatively comfortable and tranquil time.”19 Births were in the home with a midwife and one in ten newborns would not survive. Although survival rates were higher than that of England, one in four children would not make it to their $21^{\text {st }}$ birthday. The most common causes of childhood death were war, disease, and carelessness. ${ }^{20}$ After the first year, the common belief was that the child should be beaten down to create humility. Historians Demos, Earle, and Axtell refer to the writings of John Robinson on this topic who states that the stubbornness of children arising from pride must be beaten down to create humility. ${ }^{21}$

John Cotton, a prominent Puritan minister, found it was normal for very young children to "spend much time in pastime and play, for their bodies are too weak to labour, and their mind to study are too shallow."22 As Mintz and Axtell notes, his teachings were

\footnotetext{
${ }^{17}$ Stephen Mintz, Huck's Raft: A History of American Childhood (Cambridge, MA: The Belknap Press of Harvard University, 2004), 13 and Philip Greven, Four generation: population, land, and family in colonial Andover, Massachusetts (Ithaca, N.Y.: Cornell University Press), 30.

${ }^{18}$ Demos, 64 and Smith, 10.

${ }^{19}$ Demos, 131.

${ }^{20}$ Axtell, p. 71

${ }^{21}$ Demos, 134, Earle, 192 and Axtell, 89.

${ }^{22}$ Demos, 141.
} 
followed by the Northern Colonists who allowed the children under the age of seven to spend much of their time in pastimes and play. ${ }^{23}$

Children's clothing influenced both their pastimes and play. Babies, according to Axtell and Earle, were fully bound or "swaddled" until they were three weeks old. ${ }^{24}$ At this point, the arms were freed but the rest of the body was bound until age nine months. This physical molding, according to Axtell, was symbolic of the spiritual molding of these creatures of sin. Mintz disagrees with the swaddling theory. He states that "there is no conclusive evidence that the New England Puritans swaddled children." 25 Both the English customs of wetnursing and swaddling were rejected by the Puritans according to Mintz. Children were dressed in long robes and petticoats, regardless of gender, in order to prevent them from crawling. ${ }^{26}$ This practice ended at age seven with the end of “infancy”. Clothing, maturity expectations and life in general changed dramatically when childhood ended around age seven.

Children were, according to Demos and Cable, “viewed largely as miniature adults” and wore clothing similar to their parents from the age of six or seven. ${ }^{27}$ Women wore dresses with petticoats underneath, “smocks” (loose fitting undergarments), and aprons. A minimum of five layers was typical. A linen cap or "coif" covered the hair in a bun. Men wore long stockings under a linen shirt under a suit. Boots were worn most days; shoes were saved for their best clothing. Demos identifies black clothing color, so

\footnotetext{
${ }^{23}$ Mintz, 24 and Axtell, 97.

${ }^{24}$ Axtell, 85.

${ }^{25}$ Mintz, 17.

${ }^{26}$ Mintz, 16.

${ }^{27}$ Demos, 58 and Mary Cable, The Little Darlings: A History of Child Rearing in America (New York: Charles Scribner's Sons, 1975), 31.
} 
often seen in Puritan paintings, was worn for dignity and formality. Everyday clothing, according to Demos was much more colorful. ${ }^{28}$ Cable however states that the Puritan hellfire/damnation sermons suggested that bright clothing was not appropriate. ${ }^{29}$ Cable adds that by the 1700's, the sermons were not taken as seriously by children in the 1600’s. Children would still listen obediently and even take notes, but then proceed to do the opposite of what the sermon suggested they do, such as dancing, bright clothing, laughing and feeling pretty. Cable states that because of their hard work ethic, many Puritan and Quaker parents became wealthy and spent "lavishly on clothes” for both themselves and their children in the middle to later part of the colonial period. ${ }^{30}$ According to Demos, jewelry, including rings, was not worn among Puritans. ${ }^{31}$

Social rank was an important factor in clothing style. Both Bushman and Axtell concur that Northern Colonists were not legally permitted to dress above their means. ${ }^{32}$ Bushman found, “The law forbidding men of lower rank to overdress revealed the existence among common people of an urge to display fineries obtainable only through trade.”33 The New England colonies tried to cut as many ties with England as possible, thus the family and community, not Europeans dictated clothing styles.

Children up to the age of six or seven performed house or farm tasks. Mintz reports that pastimes included cutting paper dolls and playing with dollhouses for girls; flying kites, sailing toy boats, collecting rocks and bird eggs and pretending to be Indians

\footnotetext{
${ }^{28}$ Demos, 53.

${ }^{29}$ Cable, The Little Darlings, 32.

${ }^{30}$ Cable, The Little Darlings, 31.

${ }^{31}$ Demos, 54.

${ }^{32}$ Axtell, 159.

33 Bushman, 26.
} 
for the boys. ${ }^{34}$ According to Cable, Puritan children between the ages of seven and sixteen still had a few amusements including: cornhusking, rat killing, quilting, apple paring, and soap, sausage or candle making. ${ }^{35}$ Axtell found there was not an abrupt change at the age of seven in terms of pastimes, except that they were encouraged to drop their childish toys and games and acquire more serious pastimes such as hunting, fishing and homemaking. ${ }^{36}$ Gambling games were strictly prohibited for religious reasons.

Children were taught to "honor thy father and mother" as religious beliefs were strictly enforced. According to Axtell and Mintz, a child under the age of 16 could be subject to death for cursing parents unless the parents were neglectful in the child's education or the parents were extremely cruel. ${ }^{37}$ Axtell and Demos state that most discipline for children under the age of 16 occurred in the home or the school and discipline for all ages was also handled through wills. ${ }^{38}$ For example, one will stated that two sons would inherit the father's land as long as they were obedient to their mother and “carrye themselves as they ought.”39

Puritan celebrations for both adults and children were minimal, according to Cable and Mintz. The Puritans "self-consciously eliminated the revels and sports that fostered passionate peer relationships in England. ${ }^{40}$ Christmas, Easter and Valentine’s

\footnotetext{
${ }^{34}$ Mintz, 18.

${ }^{35}$ Cable, Little Darlings, 9

${ }^{36}$ Axtell, 99.

${ }^{37}$ Axtell, 155 and Mintz, 13.

${ }^{38}$ Axtell, 143 and Demos, 103.

${ }^{39}$ Demos, 103.

${ }^{40}$ Mintz, 10.
} 
Day were not holidays, but Training Day was. This was the day "where the militia was mustered” and it included parades and prizes for marksmanship.

Cable states that since the colonies were not just settled by Puritans, Puritan children saw other children laughing, singing, dancing and playing. ${ }^{41}$ Some of them longed to break the strict Puritan rules. Successive generations saw a relaxation of these rules; however play was mostly done without mix of the genders as was formal education.

Mintz explains further that the Puritans were the first group to hold an entire community responsible for the children's moral development, which resulted in the establishment of schools and criminal charges for physical child abuse. ${ }^{42}$ Puritans put high importance on reading scripture and therefore, they taught reading at an early age. Axtell states that the “distinguishing mark of New England's culture” was the Bible and the catechism that went with it. ${ }^{43}$ In the Puritans' mind, the only way to salvation was reading scripture, listening to scripture, and prayer. In the early period, education was the responsibility of the family. Mintz states that children, servants and apprentices were all required to be educated and literate. ${ }^{44}$ As Cable writes, if the village did not have a school, children and servants were required to be taught at home, with heavy fine consequences if they did not. ${ }^{45}$

${ }^{41}$ Cable, Little Darlings, 16.

${ }^{42}$ Mintz, 12.

${ }^{43}$ Axtell, 5.

${ }^{44}$ Mintz, 21.

${ }^{45}$ Cable, 8. 
By 1642, Massachusetts passed a law requiring every village of more than fifty families to have a school. Mintz states that schools were built because communities feared that the family was not properly educating the children. ${ }^{46}$ Original school $^{4}$ houses, writes Axtell, were small and primitive. They were typically a twenty by eighteen foot clapboard building with a fireplace as the sole heating source in the winter. $^{47}$ Whether the school remained open during the winter depended upon the ability of the parents to contribute wood for the fireplace. Children as young as seven were given the opportunity for education but had to do this while working as if they were adults. As Cable found, "by the time a girl was six or seven, she could sew, knit, weave and spin. At the same age, her brothers knew the principles of farming and were nearly ready to be apprenticed to whatever craft or trade they would pursue for the rest of their lives. "48

Demos states that in Puritan families, children began training at seven years old through apprenticeships during which they learned a lifetime trade. The age of seven, as Axtell notes, was also the age that illegitimate children were no longer assisted financially by their fathers because it was determined that they were of an age to work. ${ }^{49}$ Cable and Axtell state that Calvinists felt a need to put children to work earlier than other groups in order to save them from the sin of laziness and idleness. ${ }^{50}$ Menard found that in New England “a relatively weak export sector and high rates of reproduction joined to

\footnotetext{
${ }^{46}$ Mintz, 21.

${ }^{47}$ Axtell, 170.

${ }^{48}$ Cable Little Darlings, 6.

${ }^{49}$ Axtell, 98.

${ }^{50}$ Cable The Little Darlings ,6 and Axtell, 101.
} 
let employers rely on local-born youths and kept the region ethnically homogeneous by colonial standards.”51

Families believed masters were the best teachers for their apprentices. ${ }^{52}$ Children and parents decided together what God had decided for the child’s “calling”. As Cable describes it, "If, when a boy reached the age of apprenticeship, he was unable to hear what the divine voice was telling him, his parents listened for him.” ${ }^{\text {„53 }}$ Axtell reports that apprenticeships varied in length, but a 1660 Boston law required that apprentices remain until age 21 with a minimum age of seven years as shorter periods were deemed not long enough for instruction. ${ }^{54}$ Even when they had mastered their trade, many apprentices left their masters to acquire farm land when land was available. ${ }^{55}$

Boys ages ten to sixteen were trained in militia by law starting in 1645 according to Axtell. ${ }^{56}$ Hawke further describes the militia as an organization formed for social as much as military purposes. "Only the fairly well off could afford the musket, ball and shot, the pike, sword, or other military paraphernalia with which each member must equip himself."57

Religious education was well integrated into the New England colonies. Boys and girls completed their religious education training by the age of sixteen; boys continued until they could publicly answer the pastor's questions about what they had

${ }^{51}$ Russell R. Menard, “Whatever Happened to Early American Population History?” The William and Mary Quarterly, $3^{\text {rd }}$ Ser., Vol. 50, No. 2, Early American History: Its Past and Future (April 1993), 362.

${ }^{52}$ Axtell, 113.

${ }^{53}$ Cable, Little Darlings, 13.

${ }^{54}$ Axtell, 118.

${ }^{55}$ Axtell, 119.

${ }^{56}$ Axtell, 98.

${ }^{57}$ David Hawke, The Colonial Experience (Indiananapolis: The Bobbs-Merrill Company, Inc. 1966), 135. 
learned. ${ }^{58}$ Mintz and Axtell both state that due to the lack of ministers in the early part of the colonial period, the Puritan family had to accept the educational role. ${ }^{59}$ Molding the spiritual thoughts of Puritan children at an early age "was the most effective way to shape an orderly and godly society."60 Masters were required by law to catechize not only their own children but also their apprentices and servants. Cable identifies the Puritan religious conviction with the covenant that they made with God; "by promising to live by the Bible in every aspect of their lives, and by doing good works, they would be granted success in this world and salvation in the next."61 The Sunday Sabbath was for church and religious studies only; according to Cable and Axtell, there were fines for preparing meals, housework, traveling, shaving, running, kissing or sex on a Sunday. ${ }^{62}$ At a typical church service, women and girls would sit on one side of a middle aisle, the men on the other side and the boys on the stairs. The sermon went on for two hours and everyone took notes so they would not fall asleep (for which they were fined). A break would consist of a brief meal at home and then they would meet once again at the church for a standing two hour sermon. $^{63}$

Colonial New England was characterized by a relatively homogeneous group of Puritans from England. The strong religious life influenced both the family and the community in every thing they did. From the building of their homes to the upbring and education of their children, the hard work ethic and sense of importance for a spiritual life

\footnotetext{
${ }^{58}$ Axtell, 40 \& 44.

${ }^{59}$ Mintz, ix and Axtell, 21.

${ }^{60}$ Mintz, 10.

${ }^{61}$ Cable, American Manners and Morals, 18.

${ }^{62}$ Cable, American Manners and Morals, 21 and Axtell, 47.

${ }^{63}$ Cable, American Manners and Morals, 20.
} 
molded the New England family. The Middle Colonies also had a religious centered life but, as will be shown, were not nearly as homogeneous a group as the New Englanders.

\section{Childhood in the Middle Colonies}

"Embracing the principle of religious toleration this region attracted a diversity of immigrants who spoke a variety of languages. It was here, especially among the Quakers, that patterns of childhood and family life emerged that anticipated those that became common among the middle class during the nineteenth century.” ... Stephen Mintz $^{64}$

The lives of children living in the colonies of New York, New Jersey, Pennsylvania and Delaware were more diverse culturally, economically, and spiritually than the other colonial regions. So little has been written by historians about this region that some historians have pondered whether it was termed the middle colonies simply because it was a vast amount of land between the well defined Puritan North and the English South. According to Taylor, there has been ample written about the German immigration of the Quakers into Pennsylvania, some about East and West New Jersey, a fair amount on the Dutch and later English immigration into New York and very little on the Swedes and Finns in Delaware. ${ }^{65}$ Mintz described the Middle Colonies as "more pluralistic than any other portion of colonial America." the melting pot of immigrant countries and religions, historians describe many generalities about family structure, socialization and training, and childhood labor.

\footnotetext{
${ }^{64}$ Mintz, 47.

${ }^{65}$ Taylor, 53-64.

${ }^{66}$ Mintz, 47.
} 
German, Dutch and English immigrants, with a scattering of Scotish and Irish, were the main European influences in the Middle Colonies. According to Mintz, poor economic conditions in Germany, Scotland and Ireland contributed to the large influx of entire families to the middle colonies. ${ }^{67}$ They were often young couples with one or two kids or older couples with teenage children. Many German immigrants paid for their passage to the New World by selling their children as indentured servants for five to fifteen years. $^{68}$

Socialization in the middle colonies was very different than that in the Northern or Southern Colonies. The "private family”, as termed by Mintz when describing the typical Middle Colony family, was “characterized by unusually intense emotional bonding between parents and children, indulgent childrearing, and an acceptance by parents of early youthful independence.”69 According to Cable, mixed groups of boys and girls were popular and played such games as bowling on the green, golf, croquet, ice skating and sledding. ${ }^{70}$ Sunday Blue Laws prohibited children from "playing or making noise in the street on Sunday during church services." ${ }^{71}$ The consequences for breaking the law were taking away their hats or jackets and paying a fine, after which they were returned to the parents. Cable reported that "Sunday dancing, card playing, or competitive sports were not allowed, but other pastimes were permitted that young people enjoyed - sleighing and skating in winter, promenading in summer, and kissing

\footnotetext{
${ }^{67}$ Mintz, 47.

${ }^{68}$ Mintz, 47.

${ }^{69}$ Mintz, 48.

${ }^{70}$ Cable, American Manners and Morals, 59.

${ }^{71}$ Cable, Little Darlings, 25.
} 
games anytime." ${ }^{72}$ Mintz states that, unlike the Puritans, parents in the Middle Colonies emphasized equality rather than hierarchy, accepted gentle guidance rather than strict discipline, and valued early autonomy for children. ${ }^{73}$

Most Middle Colonies adopted the Dutch-German holidays. This included Saint Nicholas Day which was traditionally celebrated on December $5^{\text {th }}$. The English influence moved the date to the traditional English Christmas of December 25 ${ }^{\text {th }}$. However, in England, Christmas was not a child's celebration, so again a melding of customs resulted. The Dutch traditions of Saint Nicholas coming down the chimney with gifts for children were soon enjoyed by English children as well. Other Dutch holidays adopted by the Anglicans include New Year's, Shrove Tuesday, and May Day. Although the Dutch were originally against Anglican dancing at celebrations, by the 1700's, Cable found that "New York children and young people had a wide choice of dancing classes."

Dutch settlers in the middle colonies also followed Calvinistic principles, but sought more freedom than their New England counterparts. Cable states "they came with

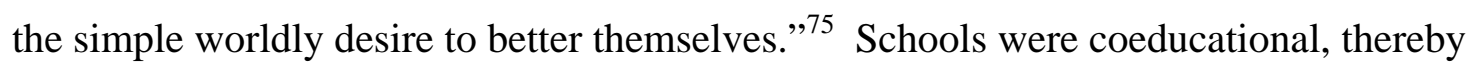
introducing the Dutch girls to the cross gender way of the world in their childhood.

Economically, the Middle Colonies produced more diverse agricultural exports than the other colonies, although wheat was the major commodity ${ }^{76}$. This increased level of trading produced a more active economy and, as noted by Menard, led to a labor

\footnotetext{
${ }^{72}$ Cable, Little Darlings, 25.

${ }^{73}$ Mintz, 49

${ }^{74}$ Cable, Little Darlings, 25.

${ }^{75}$ Cable, Little Darlings, 23.

${ }^{76}$ Wertenbaker, 25.
} 
scarcity and more need to attract labor from other ethnicities. ${ }^{77}$ Trade, however, was limited because the foreign groups (Germans, Dutch, Swedes and Finns) were permitted only to trade with England and were not permitted to trade with their home countries. ${ }^{78}$

\section{Childhood in the Southern Colonies}

"Nearly three-quarters of [the European immigrants] came to the Chesapeake and Carolina colonies. Most found this region a burial ground rather than an arena of opportunity. Disease, stunted family life, and the harsh work regimen imposed by the planters who commanded the labor of the vast majority ended the dreams of most who came.”...Gary Nash ${ }^{79}$

The large landholdings that characterized life in Virginia, Maryland, Georgia, and the Carolinas led to great distances between neighbors with very few town centers for neighbors to meet. The larger plantations assumed some of the service needs of a centralized town. As noted by historian Louis Wright, and in contrast to the New England colonies, the upper planter class in the Southern Colonies "made a conscious effort to imitate the county families of England”. ${ }^{80}$ This region was also characterized by a bi-racial society so vastly different than the other colonial regions that it transformed their community culture and family structure to be quite unique.

The first immigrants to this region landed in Jamestown, Virginia. They were mostly men from the upper rather than labor classes. They built their homes with an abundance of timber but, according to Stanard, were, "the crudest and most primitive of

\footnotetext{
${ }^{77}$ Menard, 362.

${ }^{78}$ Wertenbaker, 22.

${ }^{79}$ Nash, 59.

${ }^{80}$ The effect of slavery on childhood in the Southern Colonies was immense. However, the topic is so enormous and has been examined by so many academicians that it is only cursorily addressed herein.
} 
shanties” due to their inexperience. ${ }^{81}$ These rudimentary structures gave way to the log cabin style home which, similar to their Northern counterparts started out as one room buildings, and as time went on, developed into two room structures. This type of building continued to be home for the very poor white who lived, states Mintz, separately from their master's families. ${ }^{82}$ They were scantily furnished, with straw for beds and brass pot for cooking as prize possessions. The wealthier families built frame and brick houses which were at least forty by twenty feet with large cellars. According to Stanard, the most important rooms were the parlor, which was used for company, and the hall which was used for dining and living space. ${ }^{83}$ The Southern mansion owned by the large landowner was built in the middle to end of the colonial era and were built to incorporate hospitality. The kitchen furniture and utensils were of the most importance and often listed in detail in wills.

Steven Mintz identifies childhood in the early Southern Colonies with "highly unstable families, the prevalence of indentured servitude, and increasingly, by chattel slavery." 84 Mintz and Smith both state that the unstable family unit was the result of the comparable high mortality rates and highly skewed gender ratios among both children and adults due to disease and war. ${ }^{85}$ As the colonists built immunities to the diseases in the region and the battles with the Indians diminished, the gender ratio evened out and

${ }^{81}$ Stanard, p. 55.

${ }^{82}$ Mintz, 45.

${ }^{83}$ Stanard, p. 57 \& 63.

${ }^{84}$ Mintz, 34.

${ }^{85}$ Mintz, 34 and Smith, 13. 
stabilized the family unit. Correspondingly, attitudes toward children changed.

According to Daniel Smith,

"High death rates and a rather amorphous family structure in the seventeenth century may have placed considerable emotional distance between parents and children, but that by the middle of the eighteenth century a much more affectionate, even child -centered family environment developed, one in which children became the emotional focus of the family and as young adults were granted significant autonomy.,"86

Both Smith and Stanard describe how independence was encouraged among young people; that the young sons were encouraged to explore the plantations, often with their own slave in tow, to make sure the plantation slave labor was working hard. ${ }^{87}$

Religion was not nearly as important in the white Anglican southern society as it was in the northern colonies. According to Cable, sermons would last no more than twenty minutes and they "spent more time gossiping in the churchyard than they did worshiping in their pews.”88 Also unlike the North, Anglicans believed children were born without evil. $^{89}$ The members of the Church of England believed more in the outward acts of doing good than the necessity of the inward transformation of the Puritans. It is accurate, according to Heyrman, "to say that Anglicans mistrusted sudden, strong, public expressions of religious emotion—-the weeping, shrieking, and trembling

\footnotetext{
${ }^{86}$ Daniel Blake Smith, “The Study of the Family in Early America: Trends, Problems, and Prospects” The William and Mary Quarterly, $3^{\text {rd }}$ Ser., Vol. 39, No. 1, The Family in Early American History and Culture (Jan. 1982), 13.

${ }^{87}$ Smith, 13 and Stanard, 278.

${ }^{88}$ Cable, American Manners and Morals, 45.

${ }^{89}$ Mintz, 11.
} 
that overcame some participants in evangelical revivals. Such behavior most Anglicans disdained as unseemly and disorderly.",90

White Southern society placed much more value on socialization than training. Children of poor white families were most often servants in the plantation homes. Unlike the Northern Colonies where law mandated that masters treat their servants as part of the family for food, shelter and even education, servants in the Southern Colonial region were treated poorly.

"Southern Hospitality" was a term used for the way southern plantation owners opened their houses to strangers. Both Carson and Stanard state that people in Virginia often put strangers and visitors above themselves when entertaining and offering a place to stay for the night. ${ }^{91}$ Since there was such a huge amount of land between neighbors, travelers were always welcome into southern homes. Young people often had guests in their homes which relieved the loneliness and monotony of daily social life. Huge balls which would last for days taught southern youth social skills. Stanard reported other social entertainment included taverns, noted for dances, political gatherings and gaming and gambling, as well as visits to the bi-annual fair. ${ }^{92}$

Formal education was not as highly valued as elsewhere in the colonies. Cable indicates that the English caste system was still quite prevalent in colonies such as Virginia and one of the reasons that there were no free schools or free presses in the early

\footnotetext{
${ }^{90}$ Christine Leigh Heyrman, The Church of England in Early America (Department of History, University of Delaware) http://www.nhc.rtp.nc.us/tserve/eighteen/ekeyinfo/chureng.htm

${ }^{91}$ Jane Carson, Colonial Virginians at Play: A Colonial Williamsburg Research Series (Charlottesville: University of Virginia Press, 1965), 2 and Stanard, 58.

${ }^{92}$ Stanard, 151 and 154.
} 
part of the colonial period. As Sir William Berkeley said, "learning has brought disobedience and heresy and sects into the world; and printing has divulged them and libels against the government." ${ }^{, 93}$ Where the North valued literacy as a means toward religious salvation, the South believed that education would bring too much knowledge, leading to disobedience. Cable also states that not as many Southern children went to school because the Anglican Church did not equate salvation with education, the Royal Governor did not believe in mass education, and the large land holdings did not have many central villages to establish a school. ${ }^{94}$ Schooling, if done, was completed by a tutor in the home. Girls were taught to read; boys were taught to read and write.

Learning to dance, unlike the Northern Colonies, was considered an important part of education in the Southern Colony, according to Stanard and Cable. ${ }^{95}$ Many professional dancers set up studios and were hired to come to homes to teach students to dance. The amount and type of work for youths was also different in the South compared to the Northern Colonies.

In the Southern Colonies, tobacco was the largest commodity produced. Landowners, in general, were from the English aristocracy and were not hands on workers. The English etiquette book, The Compleat Gentleman, was followed by many Southern families in which "a gentleman, by definition, was a man who did no physical labor." ${ }^{\text {96 }}$ This philosophy of work was passed down from father to son and so very little

\footnotetext{
${ }^{93}$ As quoted in Cable, American Manners and Morals, 25.

${ }^{94}$ Cable, Little Darlings, 26.

${ }^{95}$ Cable, Little Darlings,47 and Stanard, 141.

${ }^{96}$ Cable, American Manners and Morals, 25.
} 
work was expected from plantation children, unless they were servants or slaves.

Planters sons, according to Stanard "as a rule, aspired to be and were planters only."97

When the planters exhausted their local labor market, they first tried to entice European youth to the New World by purchasing their trip in exchange for a seven year indenture. Many children were poor and serving as servants after England sent one hundred children from the streets to help solve the labor shortage in Virginia. According to Cable, this practice continued for fifty years. ${ }^{98}$ Once this labor source was exhausted, the African slave trade market developed.

\section{Summary: Regional Comparisons of Colonial Youth}

Historical scholarship provides some helpful details about the lives of colonial children. In all three regions, historians note the preponderance of documentation is available for middle and upper class youth, largely due to higher literacy levels. While more documentation is available about the environment and lives of New England and Southern children than for those in the Middle Colonies, some solid comparisons emerge among the regions. Colonial homes in all three regions started small and grew as wealth increased. The large plantation homes in the South were unmatched in the other colonies. Throughout all three regions, poorer families were housed in single room, cramped houses. The lives of children in all but the most wealthy families was dictated by small homes which, in turn, meant little, if any, privacy.

\footnotetext{
${ }^{97}$ Stanard, 102.

${ }^{98}$ Cable, The Little Darlings, 26.
} 
In New England, people built their homes in town. Thus, their families were nuclear and their communities tight-knit. In Southern Colonies, large land holdings ensured houses sat on vast acreage. Community ties focused on entertainment because of the distance between homes. The Middle Colonies focused on the nuclear family instead of community or extended family ties. This decreased the amount of socialization children had with peers and adults together.

The socialization of children in the North focused on the community and church ties. In the Middle Colonies, youth associated through social groups of mixed gender. In the South, the children of plantation families attended balls and celebrations promoted parties that would go on for days.

Education was much more important in the North where it was believed that salvation on judgment day was dependent upon one's ability to read scripture and write notes from the church sermons. Dancing and music were condemned. Formal education began in the home and continued with public schooling in some communities. In the South, due to the decentralized nature of homes, schooling was usually informally done in the home by learning real life lessons about running the plantation. Formal schooling through tutors in the home was only for the very wealthy. Dancing and music were as much a part of education as were academics. The Middle Colonies were an amalgamation of the North and South, with formal schooling important as well as the social learning of dance.

Work in the North started at age seven with an apprenticeship. This continued until approximately the age of twenty-one when a man could then begin to work and 
acquire assets to properly care for a wife and family. Girls either worked as servants in other homes or assisted mother with household chores until they married at the age of sixteen to twenty. Work experience started much later in the South where white children of landowners learned how to manage the family business, assuming they would someday take over the business. Like the North, poorer children either assisted with household chores or were servants or apprenticed out to another family. Marriage came at an earlier age since the acquisition of wealth had already occurred via their inheritance. Servants and slaves in the South, however were put to work at a much earlier age and found it very difficult to work themselves out of this indenture relationship.

Religion varied greatly by region. In New England, the vast majority of the population was Puritan who believed that hard work and constant reading of biblical scriptures was the only way to heaven. Children were born sinners and were brought up in strict religious ways. Attendance at church was mandatory and church services consumed the better part of Sunday. All activities not related to church services were penalized by law if performed on a Sunday. In the Southern Colonies, the Church of England was the denomination for the majority of the white population. Anglican thought was much more relaxed than Puritanical beliefs. Children were born pure and innocent and subsequent behavior created the sinner. Church services usually lasted no more than twenty minutes and turned into great social events after the service. In the Middle Colonies, there was such a huge mix of denominations, with the Pennsylvania Quakers, Dutch Reformed in New York and dispersion of Anglicans, Catholics, and 
Baptists in other areas, that this region was known for religious tolerance unlike the other two regions.

In conclusion, childhood differed in many important ways between the three colonial regions. These differences include religion, home, community, and education. In all areas, there was more diversity in the Middle Colonies. Most notably, there were numerous religions corresponding to the differing immigration patterns. The least amount of diversity in all areas occurred in the Northern Colonies. The Puritan religion was practiced nearly all Northerners and with it came a homogeneous pattern of family, community, and education. Race and social class in the South created a great deal of diversity, but among the white middle to wealthy class, the Church of England was the unifying religion. Race and social class did dictate the type of family and community life as well as education offered to youth in the Southern Colonies. 


\section{INTRODUCTION TO LESSON PLANS}

This lesson plan examines the activities of youth in the Colonial Period. As such it incorporates much of the material from the historiography that focused on youth activities on a regional basis. The lesson plan is combined with a traveling exhibit to be used by teachers on a checkout basis from the Clarke Museum in Eureka, California. The lesson is designed for fifth graders and incorporates standards for fifth grade as shown in Appendix A. This ten-day lesson plan is designed to help fifth grade students take an indepth look at a typical day for a youth in the colonial period. The lesson plan explores the typical shelter, clothing, food, work, and play of a colonial youth.

The timeline for the lesson plan is as follows:

Day One: Hook and Geography. After the hook, students will learn about the three different colonial regions: New England, Middle, and Southern Colonies. A map will be shaded in and a demographic handout will be analyzed. Students will be broken up into three “regions” - New England, Middle, and Southern Colonies - as answers will differ dependent upon region.

Day Two: Shelter. Students will first form the walls of a typical colonial home.

Students will be selected to enter the home and prepare the meal, sit for dinner, and lay down for sleep. Then children will be given graph paper to lay out their "home" and make a list of furniture and utensils they think would have been part of the inventory of the house. Students will also play a part in making a typical colonial food. 
Day Three: Clothing. Students will explore the clothing of babies, toddlers and the transition to adulthood at age seven.

Day Four: Play. Students will learn that up until age seven, children were more free to play. Today’s lesson plan will explore colonial games.

Day Five: Work. Students will learn about the lives of toddlers to age seven and the work they had to accomplish. Students will create a sampler with their initials and a design.

Day Six: Work after age seven. Students will learn about the working world of children over the age of seven. They will complete a questionnaire about their "calling”, pretending they are seven year olds. Then they will complete an indenture agreement which explains what is expected of them and what is expected of their masters.

Day Seven: School. Students will spend a day in a typical school room and create a hornbook.

Day Eight: Church. Students will listen while the teacher reads a sermon from John Cotton. They will be told they can not be wiggling and must pay attention to every word spoken. Then the students will be broken up into their regions to analyze Northern and Southern sermons.

Day Nine: Conclusion. Students will summarize in their diaries what they have learned about colonial children in their region.

Day Ten: Evaluation. A "foldable" exercise which will jigsaw children to form new groups with children from other regions and then the final entry in their journal where they discuss the comparisons. 


\section{Prior Content Knowledge and Skills}

Students should have prior knowledge that the immigration of Europeans to the New World. The day before the unit starts, the teacher should do a KWL (Know, Want to Know, Learned) chart regarding immigration (do the Know and Want to Know before the unit starts and the Learned column after the unit is over). Students should also know what a diary is and be shown the rubric for how their diaries will be graded.

\section{Discussion of Content Hook and Theme}

The hook is a diary entry to be read by the teacher. Students will begin keeping their own diary of their colonial experiences through the lesson plans which walk them through typical activities of colonial youth. The diary will be written on paper with a quill pen and all entries will then be bound into a book. The class will be split into three groups - representing the three colonial regions. Students will be perform a "jigsaw" activity at the end of the unit so that they can compare and contrast their regional experiences. The overall theme for the unit is that youth experiences varied by geographical region. 


\section{LESSON CONTENT}

\section{Day One: Hook and Geography}

Materials needed:

- Cardstock

- Unlined paper (at least 10 pieces per student)

- $\quad$ Feather with tip cut diagonally to use as writing instrument (Quill)

- Ink

- Ink blotter (paper towel on top of a plastic lid or Styrofoam tray works well)

- Blank maps for overhead and student handout (Appendix B)

- Overheads of regional and immigration maps in Appendix B

- Demographic information Handout (Appendix B).

Read the diary to the class in Appendix B. ${ }^{99}$ Mary Cooper and her family were farmers. Mary Cooper was 55 when she began writing her diary in 1769 on Long Island. Show students where Long Island is located on a map. Discuss with students how hard they worked every day, how they always attended church each week and how common it was that her diary entries, and those of other diaries began with a summary of the weather. Ask students to try to interpret the words in each entry and to try to envision

\footnotetext{
${ }^{99}$ The full diary is available from the Oyster Bay Historical Society. An excellent interpretation of Mary Cooper's diary has been written by George DeWan, a staff writer for Newsday. It can be found at: http://www.newsday.com/community/guide/lihistory/ny-history-hs331a,0,7319850,print.story?coll=nylihistory-navigation. A picture of the diary can be found at http://www.newsday.com/community/guide/lihistory/ny-history-hs301i87,0,6035399.photo.
} 
themselves at a desk writing this diary. Then explain to the students that they will be creating their own diary for their own experience as a colonist over the next ten days. Hand out the cardstock, quill, and ink and have the students write the word "Diary" on the cardstock approximately three inches from the top. This will be the cover page for their diary. Below "Diary" they should write their name and then the colony in which they live and then the year, 1672. See teacher reference for splitting the class in Appendix B.

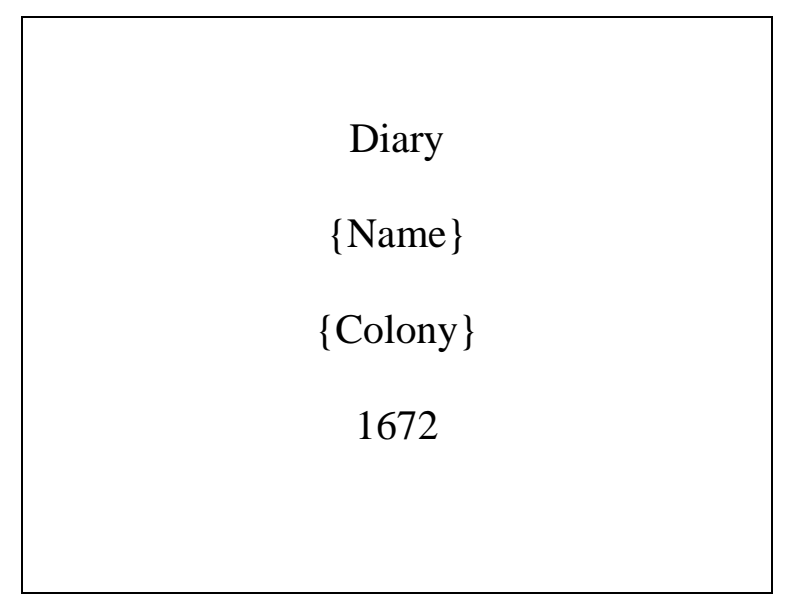

Discussion: The thirteen original colonies are the first places immigrants landed in what is now called America. The colonies are roughly similar to the present day states, although many are smaller today than their original boundaries. Show the first overhead map in Appendix B that consists of a blank map of the colonial boundaries and pass a copy out to each student. These original colonies were grouped into three regions: the New England Colonies in the North, the Middle Colonies, and the Southern Colonies. Put the next overhead on which shows the three regions and have students use a marker to trace lines around the colonies comprising each region. Finally, discuss that part of the 
reason there are these three regions is due to the immigration patterns of the European immigrants. Put the last overhead map which shows not only the colonies and the three regions but also the immigration patterns. Have students use different color markers to show these different groups on their maps and how to use a legend which identifies which nationality belongs to which color. Then, split up the class into colonies as identified in the Appendix B chart titled “Class Split for Colonies”.

Next, students will look at the information in the Demographic handout and answer the questions.

Finally, students should write their first diary entry about where they came from and where they are now living. Remind them to start their entry with a summary of the weather today. To enrich this activity for advanced students, they could research more about their colony or they could research why they left their home country. ${ }^{100}$

\section{Day Two: Shelter}

Materials needed:

- $\quad$ Plimouth Plantation article (Appendix C).

- Overheads of colonial houses (Appendix C)

Discussion: The discussion will start with an article from the Plimouth Plantation website about the Pilgrims view of housing as they landed in the New World. The teacher should read his out loud or have students take turns reading the article out loud.

\footnotetext{
${ }^{100}$ An excellent website for this activity is located at www.socialstudiesforkids.com/graphics/13mapnew.htm.
} 
Students will first go outside and form the walls of a typical colonial home. The teacher should have laid out the dimensions of twenty feet by twenty feet. Ten students will be selected to play the two parents and the eight children. The teacher should tell the entire class that their diary entry today will assume that they are a ten year old, regardless of the roles they may take on. First, add a table to the "room" and two chairs. Then discuss the sleeping arrangements - have mom and dad lie down in one corner of the house and then add one child - the baby - in between them. Have the other seven children "find" a place to lie down and sleep. The teacher should feel free to tell students that they need to move over as they are sleeping in the fireplace or on the table. Discuss colonial bedding - sometimes just a blanket on the floor; other times a wood frame with rope loosely woven and a "mattress" of old rags and wool or feathers (if wealthy). Then the students can “wake up” and pretend to prepare for breakfast.

Mom should be by an area designated as the fireplace pretending to cook a meal with a pan. Dad should be seated at the table and the children should stand - all will pretend they are eating. The teacher should ask questions like "How do you think you would like standing for every meal?” "Why do you think the children are standing?” Discuss the fact that the colonists had minimal furniture and having a chair for every child was not only expensive but they did not have enough room for all of that furniture. Discuss the eating utensils - plates were often made of wood, spoons were made of pewter and were very valuable, knives were shared and forks were almost unheard of. Then children will go inside and be given graph paper to lay out their "home" and make a list of furniture and utensils they think would have been part of the inventory of the 
house. Students will be broken up into three "regions" - New England, Middle and Southern Colonies - but answers will not differ dependent upon region.

For enrichment, students could do research on homes in the later part of the colonial era as houses were much larger for the wealthy families, especially in the South. Another enrichment idea would be for students to research "milk paint ${ }^{101}$. Next, students will make a colonial food item. There are many recipes on the internet for colonial food $^{102}$. An excellent class discussion could occur while the food is cooking about what food was available then, how the food would be obtained, and how the food was cooked or preserved.

Before writing their diary entry, show students what colonial houses looked like. A couple of examples are depicted in Appendix C. Students will then write their diary entry for Day Two summarizing what housing and food was like for them as if they were a colonial child.

\section{Day Three: Clothing}

Materials needed:

- Baby doll

- Fabric approximately eighteen inches by two yards (an old sheet ripped up to these dimensions works well)

- Overheads in Appendix D

\footnotetext{
101 " see www.milkpaint.com/articles.htm\#TheNewYorkTimes for more information on milk paint.

${ }^{102}$ For recipes for colonial food, see http://www.history.org/Almanack/life/food/foodhdr.cfm or http://www.1771.org/cd_recipes.htm.
} 
Discussion: Students will explore the clothing of babies, toddlers, and the clothing transition to adulthood at age seven. Children's clothing in the colonial era was vastly different than clothing styles today. Babies were swaddled. The teacher can write the vocabulary term "swaddled" on the board. Show students how babies were swaddled using the baby doll and the fabric. First, the teacher should wrap the fabric around the baby from neck to toes. Explain that this was the method of swaddling until the baby was about three weeks old. Then rewrap the fabric around the baby from neck to toes with the exception of the arms. Swaddling was mainly done to maintain good posture and development and to make sure babies would not crawl and dirty their clothing. Some historians write that the Puritans in the New England region did not agree with swaddling their babies. Once children were old enough to walk (approximately one year of age), all children (both boys and girls) were clothed in dresses. Show the first overhead in Appendix D. At age seven, children started dressing like miniature adults as seen in the second overhead and pictures of adults in the remaining overheads. ${ }^{103}$

As the final activity, students should write in their diary about the clothing they wore as a baby, a child, and now as a little adult. Students can choose the income level they would like to dress like or the teacher can assign it (teachers should preview Day Five when students will be choosing an occupation).

\footnotetext{
${ }^{103}$ An excellent interactive website should be shown at this point. Go to http://www.history.org/history/clothing/intro/index.cfm and click on "Dressing the Part: An Interactive adventure". The teacher can show children what a poor farmer, middle income trades person or a wealthy person wore.
} 


\section{Day Four:}

Materials Needed:

- Stool

- Balls

- Cup and ball toy

- Chalk

- Stones

- Hula hoops

- Sticks (stir sticks from the paint department work well)

Discussion: Up until age seven, children were more free to play. After age seven, children's play in the Northern colonies and poorer Southern families was strictly limited as society felt that children at this age should be put to work to begin to learn a trade. Today’s lesson plan will explore colonial games.

The first game is Stool ball and is described in Appendix E. This game would be appropriate for the entire class to participate and can easily fulfill physical education standards at the same time. One or two students are chosen to defend the stool (a common day kitchen stool turned upside down works perfectly) while the other students form a circle and run around in that circle while passing a ball or two and frequently try to hit the stool with the ball.

The other five games listed in Appendix E are either individual or small group games and would be appropriate to be set up as centers that students could rotate through. The second game in Appendix E lists the rules of Hop-round, a game similar to current 
day hopscotch. Students throw five stones onto the divided circle drawn with chalk. They must hop on one foot to each spot with a stone, stoop to pick it up, continuing until all five stones are retrieved.

The game of Hoop-Toss in Appendix E develops hand-eye coordination as students attempt to keep a hula hoop upright and moving forward using a stick inside the hula hoop. In the Colonial period, wagon wheel frames were used for this game.

A popular game, especially in the South, was the game of Nine Pins. In Appendix E, the layout of the nine pins is diagramed. Cone shaped wooden pieces were used in the colonial era, but current days teachers can substitute such items as small water or soda bottles for the pins. A ball is rolled to try and knock down the pins, similar to current day bowling. Green grassy areas close to the courthouse were commonly set aside for Southern colonials to play nine pins while taking a break from attending the periodical judicial presidings.

The Ball and Cup toy was a common gift for an average to wealthier colonial child. As depicted in Appendix E, this game utilizes a wooden cup on top of a stick with a small ball attached with string. Children try to swing the ball up into the cup.

The game of Fox and Geese, as shown in Appendix E, is a board game which is a combination of modern day checkers and Chinese checkers. One player manuevers the Fox and the other player maneuvers the fifteen Geese. The winner is either the Fox who “eats” all of the Geese or the Geese who “corner” the Fox.

Finally, children should write their diary entry describing the games they played. 
Day Five: Work for toddlers to age seven

Materials Needed:

- Rules in Appendix F

- Aida cloth (each piece cut to 2” x 6”)

- embroidery floss (a simpler alternative would be to have students mark their X’s on graph paper.)

- Copy of handout from Appendix F depicting a sampler alphabet

Discussion: Students will discuss household chores and then learn how to make a sampler bookmark with their initials and a design. From the time they start walking to the day there are deemed adults (seven in New England colonies), children helped with the simple chores around the house. Have students brainstorm what chores they think would be done in a colonial home. The teacher can assist with supplemented answers as needed with the following list:

- Milking the cow

- Gathering eggs

- Weeding the garden

- Sweeping the floor

- Boys - assisting Dad in his occupation, learning to hunt and fish

- Girls - assisting Mom with cooking, cleaning, watching the baby, learning to knit, sew and weave

Then the teacher can discuss how much stricter Northern colony parents were by sharing the Northern Colony rules in Appendix F. This can be done via overhead, but 
would be very effective if written on poster board and hung in the classroom for the remaining days of the unit.

Then, the teacher passes out Aida cloth and children create a sampler consisting of their initials and a simple design. A graph of letters can be found at Appendix F. The teacher should tell students that this was a popular method of teaching children their alphabet at the same time that they are learning how to do simple stitchwork. Finally, students should write their diary entry for the day, describing a typical day for their fiveyear old brother or sister, including household chores and learning to do stitchwork.

Day Six: Work for a colonial child beginning at age seven

Materials:

- Girls Questionaire (Appendix G)

- Boys List of Apprenticeships Available (Appendix G)

- Indenture Agreement (Appendix G)

- $\quad$ Story of Benjamin Franklin (Appendix G)

Discussion: Children complete a questionnaire (girls) or review a list of potential occupations (boys), pretending they are Northern colony seven year olds. In the New England Colonies, determining your “calling” was a spiritual concept. Children were expected to receive word from God about what their future occupation would be; otherwise their parents would choose for them. The teacher should remind students that in the Southern region, wealthier children were not brought into apprenticeship at such an early age, with the exception of simply observing their parents and starting to assume 
some of the responsibilities of the family business. In the Middle region, many children were apprenticed and today’s unit will end with a story about Ben Franklin.

Girls should make one of the three choices after reading the short story in Appendix G. Choices for girls are: Huswifery (learning how to maintain a house), learning the midwife trade, or working in another family’s home as a Household Servant. The choices for boys for apprenticeships are: Basketmaker, Blacksmith, Bookbinder, Brickmaker, Cabinetmaker, Carpenter, Clergy, Cooper, Farmer, Founder, Harnessmaker, Gunsmith, Milliner, Printer, Rural Trades, Shoemaker, Weaver, Wheelwright, Wigmaker. After completing the questionnaire, students will complete an indenture agreement which explains what is expected of them and what is expected of their masters. $^{104}$

Then the teacher will read the story of Benjamin Franklin and his quest to find an occupation. The teacher can introduce the story by saying that finding a future occupation was not always a simple one. Benjamin Franklin pursued several different apprenticeships before finding the one that suited him best.

Finally, students will write their diary entry about their future occupation and how they will be trained.

\section{Day Seven: School}

Materials Needed:

- $\quad$ Picture of hornbook on overhead (from Appendix H)

\footnotetext{
${ }^{104}$ See http://www.history.org/media/ for an interactive source on trades.
} 
- Cardboard

- Parchment Paper

- Pen

Discussion: Hornbooks were used by school children in all three regions to teach the alphabet. Appendix H contains a photo of an actual hornbook. In New England, children attended classes in established buildings whereas in the Southern Colonies, due to the large amount of land between houses, wealthy families hired tutors to live with their family. The hornbook, a form of ABC book consisted of a piece parchment or paper pasted onto (most commonly) a wooden board and protected by a leaf of horn. The size of the board was small; most were about 2" x 3”. A cross usually started the text in the top left-hand corner. Next came the alphabet, then sets of word combinations producing the most common sounds, then the invocation to the Trinity, and finally the Lord's prayer was printed. The horn-book was often known as the "Crisscross-row" or "Crisscross," which was either a reference to the cross at the top of it, or the way in which the text is set up to be read.

To create the hornbook, the teacher should have a copy of the hornbook template in Appendix H for each student. Students should carefully cut around the outer template and use this to trace around onto a piece of cardboard. The cardboard is then cut on the lines drawn. This is the back of the hornbook. The inside template is then cut out and can be used for the hornbook or traced onto parchment paper to be more authentic. Tell the students they will need to write small and neat. From the picture of the hornbook, 
guide them through each line, starting with the cross, through the alphabet (in both lower case and capitals), the vowels, the common sounds, the invocation and the Lord's prayer.

\section{Day Eight: Church.}

Materials Needed:

- Sermons in Appendix I

Discussion: Students will be given copies of the sermons in Appendix I, according to the regions they have previously been assigned. Middle Colony students can be split between the two groups. The teacher should begin the conversation by discussing some of the fundamental differences between the Puritans and Anglicans.

- The Puritans arrived in the New World hoping for a chance to escape the Anglican influence. Puritans practiced a strict religion which focused on memorizing scripture and attending church services twice on Sunday (each service lasting about two hours long) and often one more day of the week. Church buildings were not ornate and most often had no heat during the long winter services. Sermons centered around the belief that no person would be eligible for heaven unless they found salvation through an internal spiritual enlightenment. Women and girls sat on one side of the church, men on the other side and the boys sat on the stairs. Sundays were sacred; members were not allowed to do anything other than attend services and go home to read the bible and eat. Even the cooking had to be done the day before. 
- Most of the colonists living in the Middle and Southern Colonies attended the Church of England. This Anglican service combined many traditions and prayers and church members often attended in ornate buildings. The entire service would last no longer than an hour; many times under half an hour. Families sat together. The sermons focused on the reasonableness of Christianity and preached that people were innately good. The social time after the service was often longer than the service itself.

After the students have had a chance to analyze the tone of the sermons, they should complete their diary entry as if it was a Sunday and they had attended church services. They should describe the church building, the sermon, and how they spent the rest of the day.

\section{Day Nine: Conclusion.}

\section{Materials Needed:}

- Legal size paper

Discussion: In order to summarize the eight different aspects of colonial life as a youth, students will summarize what they know in a "foldable" exercise. Students should fold their piece of legal paper as follows:

- With a ruler, draw a line one inch from the edge on one short end and one long end. 
- With the remaining paper, students should fold their paper twice for the short height and four times for the longer width. The finished product should look like the diagram below.

- Students should mark their rows and columns with the name of the Colonial regions and the eight aspects of Colonial life which were explored as follows:

\begin{tabular}{|c|c|c|c|c|c|c|c|c|}
\hline & Geography & Shelter & Clothing & Games & $\begin{array}{l}\text { Work } \\
\text { Age 0-7 }\end{array}$ & $\begin{array}{l}\text { Work } \\
\text { 7-adult }\end{array}$ & School & Church \\
\hline $\mathrm{N}$ & & & & & & & & \\
\hline $\bar{M}$ & & & & & & & & \\
\hline$S$ & & & & & & & & \\
\hline
\end{tabular}

Students should then proceed to complete what they know for each topic only in the Northern, Middle or Southern Colonial region they are from.

Day Ten: Comparison and Evaluation

Materials Needed:

- $\quad$ String

- Hole punch 
Discussion: To conclude the unit, students will compare what they know with other students, write their final diary entry, and then bind their diary book.

First, the teacher should have students sit with other members of their region. Within each region, students should count off. The “jigsaw” exercise is performed when all of the number "ones” group together, all of the number "twos” and so on. Students should bring their foldable exercise from the previous day and present to the students in their small group what they know about their region while the other students fill in their chart. The groups are done when all charts have been filled in.

Next, the students will make their final entry in their diary. They should pretend that they met two new people today - one from each of the other regions. They should describe the differences and similarities.

Finally, students will punch holes in their diary sheets and cover pages one inch apart on the left side and half an inch from the end. String should be woven through the holes to complete the binding for their book.

A grading rubric for the diaries is provided in Appendix J. 
APPENDIX A

CALIFORNIA STANDARDS ADDRESSED 
California State Standards

Standards at the fifth grade level are addressed in this lesson plan. In addition, Movement Skills and Movement Knowledge Goals in the Physical Education Framework are attained via the games.

\section{Fifth grade social studies standards:}

Standard 5.4 Students understand the political, religious, social, and economic institutions that evolved in the colonial era.

1. Understand the influenced of location and physical setting on the founding of the original 13 colonies, and identify on a map the locations of the colonies and of the American Indian nations already inhabiting these areas.

3. Describe the religious aspects of the earliest colonies (e.g. Puritanism in Massachusetts, Anglicanism in Virginia, Catholicism in Maryland, Quakerism in Pennsylvania).

\section{Kindergarten through Grade Five Historical and Social Sciences Analysis Skills:}

\section{Chronological and Spatial Thinking:}

1. Students place key events and people of the historical era they are studying in a chronological sequence within a spatial context; they interpret time lines.

2. Students correctly apply terms related to time, including past, present, future, decade, century and generation.

3. Students explain how the present is connected to the past, identifying both similarities and differences between the two, and how some things change over time and some things stay the same. 
4. Students use map and globe skills to determine the bsolute locations of places and interpret information available through map’s or globe’s legend, scale, and symbolic representations.

Research, Evidence, and Point of View:

Historical Interpretation:

1. Students summarize the key events of the era they are studying and explain the historical contexts and events.

2. Students identify the human and physical characteristics fo the places they are studying and explain how those features form the unique character of those places. 


\title{
APPENDIX B \\ COLONIAL GEOGRAPHY (DAY ONE)
}

\author{
Diary of a Colonial Housewife \\ Diary Entries for Various Ages \\ Class Split for Colonies \\ Map of the Colonies \\ Map of the Colonial Regions \\ Colonial Map (immigration patterns) \\ Colonial Demographics
}


Diary of Mary Cooper, a Colonial Housewife

Source: http://www.newsday.com/community/guide/lihistory/ny-historyhs331a,0,7319850,print.story?coll=ny-lihistory-navigation

\section{July the 13, 1769. Thirsday.}

This day is forty years sinc I left my father's house and come here, and here have I seene littel els but harde labour and sorrow, crosses of every kind. I think in every respect the state of my affairs is more then forty times worse then when I came here first, except that I am near the desierered haven. A fine clear cool day. I am un well.

Friday, July 7, 1769.

Hot as yesterday. I am dirty and distressed, almost weared to death. Dear Lord, deliver me.

Wednesday, August 23, 1769.

A fine clear morning with a cold north wind. My hearte is burnt with anger and discontent, want of every nessesary thing in life and in constant feare of gapeing credtors consums my strenth and wasts my days. The horror of these things with the continuel cross of my family, like to so many horse leeches, prays upon my vitals, and if the Lord does not prevent will bring me to the house appointed for all liveing.

\section{June the 29. Tuesday.}

South west wind, cloude, some thunder and a fine shower of rain this after noon and a bright rain bow appeared some thing longer then uesal which raised my thoughts to the bright relms of day. I longed to se that head once crowned with thorne, that dear parson treated with scorn and cruelty for sinful me. The dasling luster of his face I faint. I can find no word to express my ideas, my greatest vews seeme to be of my Jesus seated on a throne of glory in the bright relms of etarnel day. The pleasing luster of his eyes out shine the wonders of the skys. In raptures and sweet delight I fell a sleep. $O$, that my last moments may be like these.

January, 1764:

Tuesday the 24 was a Very bad Snow Storm a great Snow fell to Day before this storm had been a fine Spell of Wether Very warm for Saturday february ye 10 Day we finished thrashing We have 32 bushels of wheat in the house 
Diary Entries for various ages

\section{Girls 4 - 8}

Source: http://www.nps.gov/fofr/col_kids.htm

"The cutting of this cone of sugar, weighing 9-16 lbs, into lumps of equal size and regular shape was distinctly the work of the mistress and daughters of the house."

"Picking geese was a chore performed by the young children. 3 or 4 times a year, the feathers were stripped from the live birds."

\section{Girls $9-12$}

An entry from a 1775 journal of a young girl lists 26 chores accomplished:

" Fixed gown for Prude, mend Mother's Riding Hood, Spun short thread, Fixed two gowns for Welsh's girls, Carded tow, Spun linen, Worked on cheese basket, Hatchel'd flax with Hannah, 51 pounds each, Pleated and ironed, Read sermon of Dodridge's, Spooled apiece, Milked cows, Spun linen-50 knots, Made broom from Guinea wheat straw, Spun thread to whiten, Set a red dye, Had 2 scholars for Mrs. Taylor, Carded 2 pounds of wool Nationally, Spun harness twine, Scoured pewter, Ague in face, Ellen spark'd last night, Went to Mr. Otis's and made them a swinging visit . . ."

\section{Boys 4 - 8}

"Playthings for children were few in number, save the ones they manufactured for themselves."

"One of the duties of children was to gather a kind of horsetail rush which grew in thee marshes and because it was used to scour pewter, was called the scouring rush" "Some of the preparation of corn fell upon the boys: it was their regular work in the evening firelight to shell corn from the ears ..."

\section{Boys 9 - 12}

"The boy was taught that laziness was the worst form of original sin. Hence, he must rise early and make himself useful before he went to school, must be diligent there in study, and come promptly home to do "chores" at evening. His whole time out of school must be filled up with some service, such as bringing in fuel for the day, . . . feeding the swine, watering the horses, picking the berries, gathering the vegetables, spooling the yarn. $\mathrm{He}$ was expected never to be reluctant and not often tired."

\section{Teens}

"Large numbers of women were wedded at sixteen, and if a girl remained home until her eighteenth birthday her parents began to lose hope."

"Boys reached estate at sixteen years of age, became taxpayers, and served in the militia." 
Class Split for Colonies

Note: Depending on class size, students can have repeat locations, as needed.

Recommend that New England and Southern Colonies use more repeat locations than the Middle Colonies.

\begin{tabular}{|c|c|c|c|}
\hline $\begin{array}{l}\text { JIGSAW } \\
\text { GROUP } \\
\text { DAY } 10\end{array}$ & $\begin{array}{l}\text { NEW ENGLAND } \\
\text { COLONIES }\end{array}$ & $\begin{array}{l}\text { MIDDLE } \\
\text { COLONIES }\end{array}$ & $\begin{array}{l}\text { SOUTHERN } \\
\text { COLONIES }\end{array}$ \\
\hline 1 & $\begin{array}{l}\text { Massachusetts - } \\
\text { Puritan (from } \\
\text { England) }\end{array}$ & $\begin{array}{l}\text { Pennsylvania - } \\
\text { Quaker (from } \\
\text { Germany) }\end{array}$ & $\begin{array}{l}\text { Virginia - } \\
\text { Anglican (from } \\
\text { England) }\end{array}$ \\
\hline 2 & $\begin{array}{l}\text { Massachusetts - } \\
\text { Puritan (from } \\
\text { England) }\end{array}$ & New Jersey & $\begin{array}{l}\text { Maryland - } \\
\text { Anglican (from } \\
\text { England) }\end{array}$ \\
\hline 3 & $\begin{array}{l}\text { New Hampshire - } \\
\text { Puritan (from } \\
\text { England) }\end{array}$ & $\begin{array}{l}\text { New York- } \\
\text { Dutch Reformed } \\
\text { (from Holland) }\end{array}$ & $\begin{array}{l}\text { Georgia - } \\
\text { Anglican (from } \\
\text { England) }\end{array}$ \\
\hline 4 & $\begin{array}{l}\text { Rhode Island - } \\
\text { Puritan (from } \\
\text { England) }\end{array}$ & $\begin{array}{l}\text { New York - } \\
\text { Anglican (from } \\
\text { England) }\end{array}$ & $\begin{array}{l}\text { North Carolina - } \\
\text { Anglican (from } \\
\text { England) }\end{array}$ \\
\hline 5 & $\begin{array}{l}\text { Connecticut - } \\
\text { Puritan (from } \\
\text { England) }\end{array}$ & $\begin{array}{c}\text { Delaware - } \\
\text { (from Sweden) }\end{array}$ & $\begin{array}{l}\text { South Carolina - } \\
\text { Anglican (from } \\
\text { England) }\end{array}$ \\
\hline
\end{tabular}




\section{Map of the Colonies}

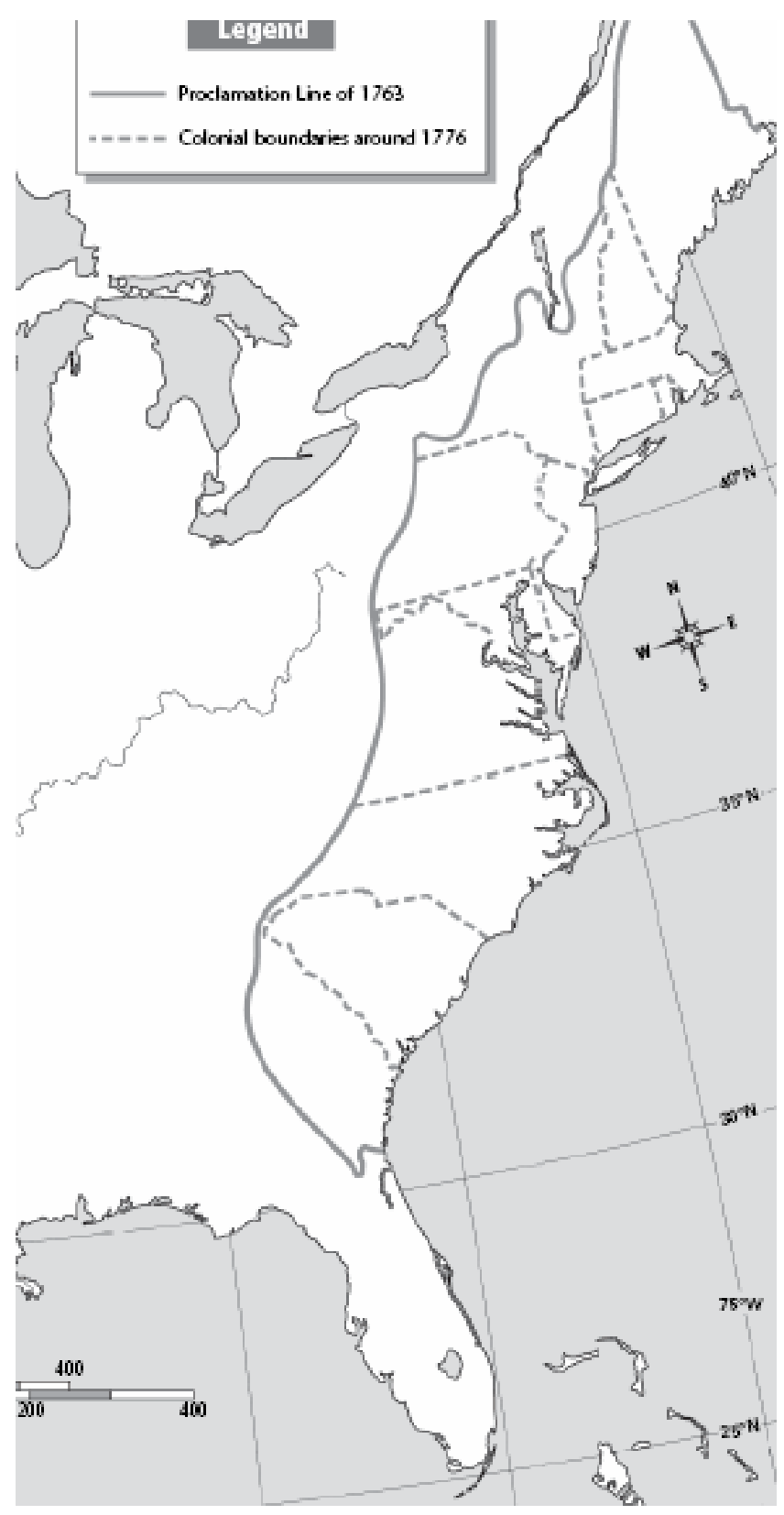

Note: The above map is from http://www.eduplace.com/ss/maps/pdf/us1776.pdf and is may be printed or copied for classroom or personal use only. 
Map of the Colonial Regions

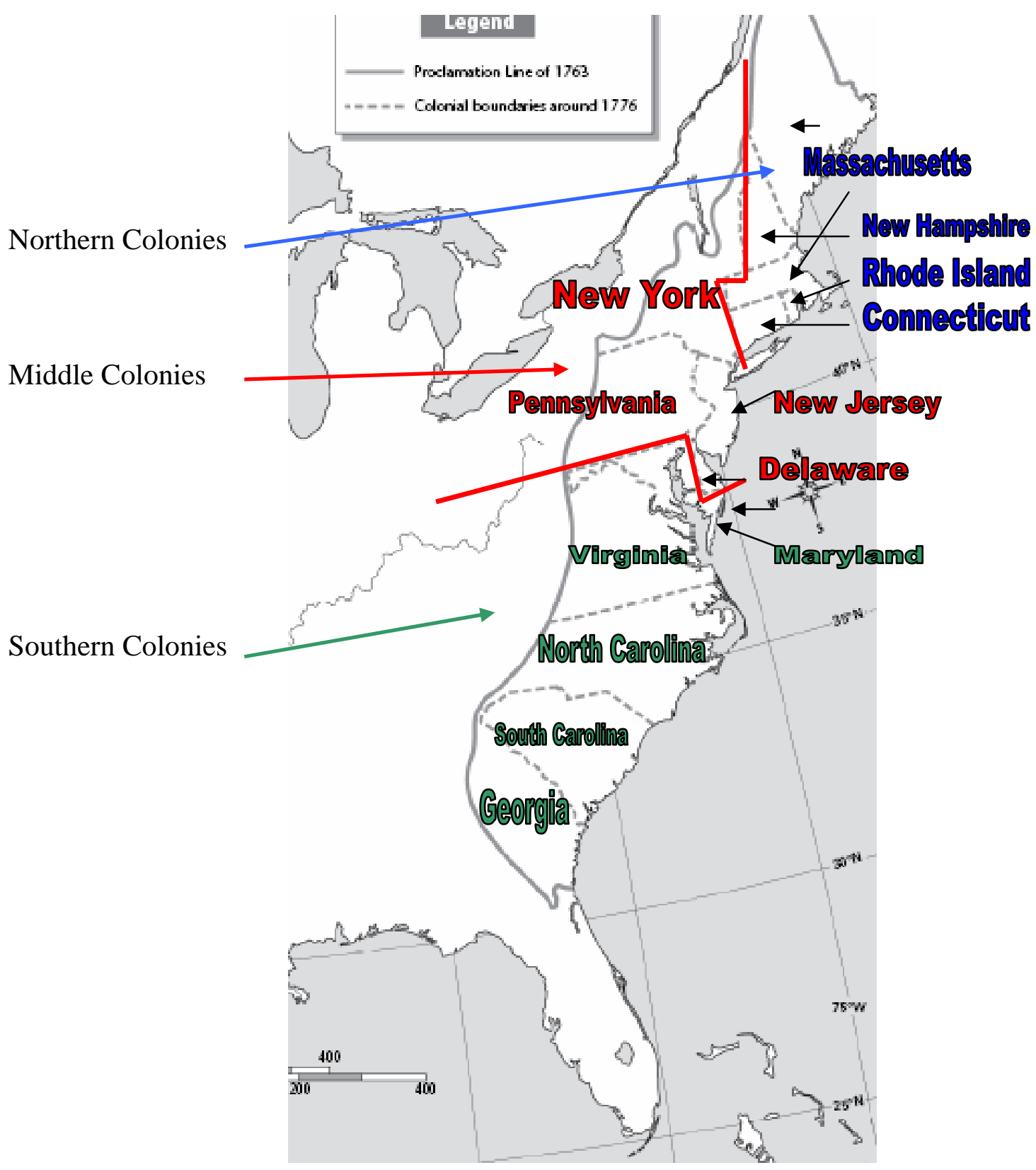

Note: The background map above is from

http://www.eduplace.com/ss/maps/pdf/us1776.pdf and may be printed or copied for classroom or personal use only. 
Map of the Colonial

Immigration Patterns

\begin{tabular}{||l|c||}
\hline \hline $\begin{array}{l}\text { IMMIGRANT } \\
\text { GROUP }\end{array}$ & \\
\hline African & Black \\
\hline Dutch & Red \\
\hline English & Blue \\
\hline German & Yellow \\
\hline Scotch-Irish & Orange \\
\hline
\end{tabular}

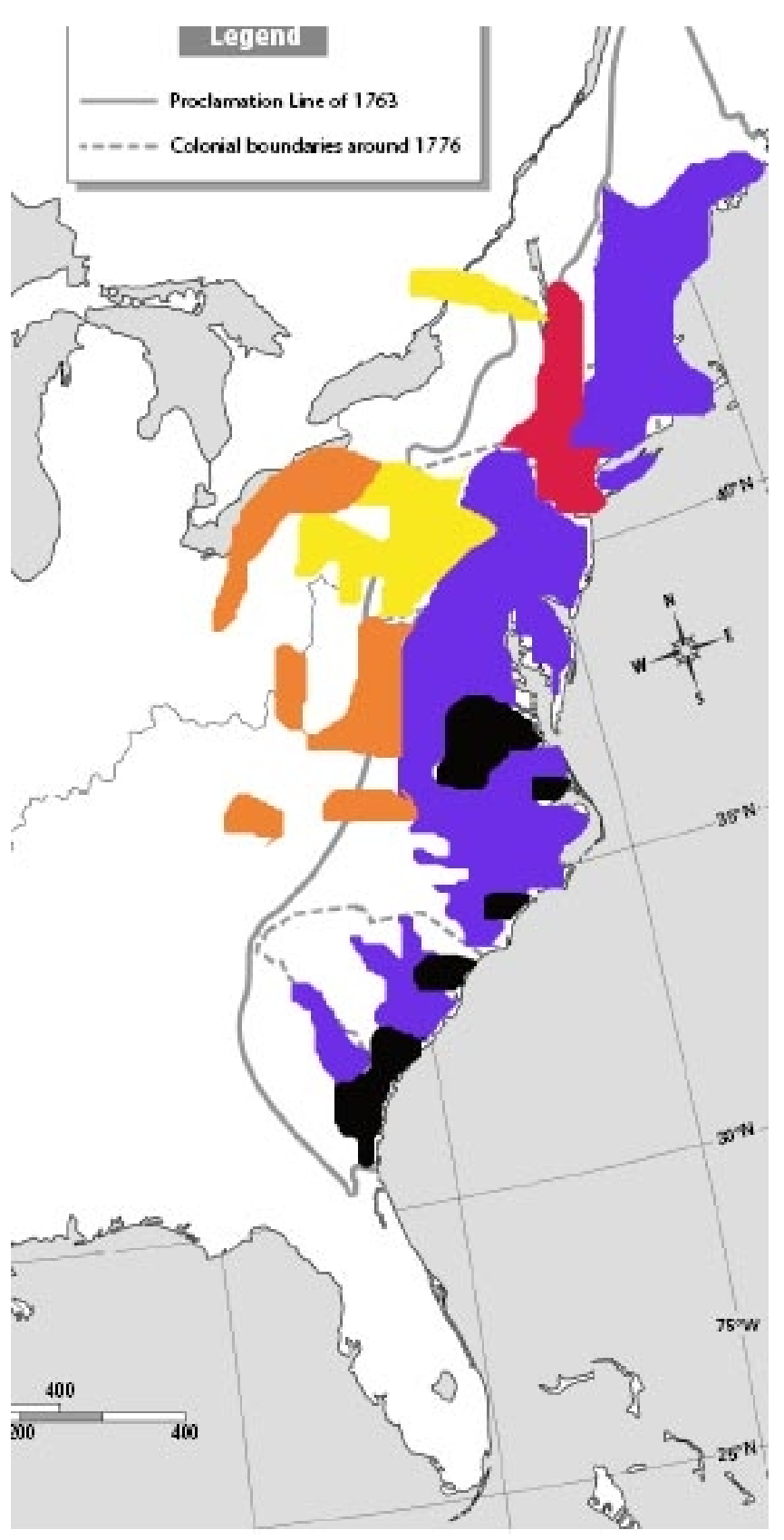

Source Note: The background map above is from http://www.eduplace.com/ss/maps/pdf/us1776.pdf and may be printed or copied for classroom or personal use only. 
Colonial Demographics

Source: http://www.digitalhistory.uh.edu/historyonline/us3.cfm

\section{Colonies}

\begin{tabular}{|l|l|}
\hline \multicolumn{2}{|c|}{ Starving times: Crude death rate first winter } \\
\hline Jamestown & Plymouth \\
\hline 638 (per thousand) & 490 (per thousand) \\
\hline
\end{tabular}

In 1607, the Susan Constant discharged 105 passengers; six months later, two-thirds were dead.

Between 1607 and 1624, 6,000-10,000 colonists arrived; but only I,275 remained alive.

\begin{tabular}{|c|c|c|}
\hline \multicolumn{3}{|c|}{ Child Mortality in New England } \\
\hline \multicolumn{3}{|c|}{$\begin{array}{l}\begin{array}{l}180-200 \text { of every } 1,000 \text { died first } \\
\text { year }\end{array} \\
\begin{array}{l}35-40 \text { percent failed to reach } \\
\text { adulthood }\end{array}\end{array}$} \\
\hline \multicolumn{3}{|c|}{ Death rate for infants in Salem, Mass. (per thousand) } \\
\hline & 17th century & 18th century \\
\hline Girls & 313 & 178 \\
\hline Boys & 202 & 105 \\
\hline \multicolumn{3}{|c|}{ Causes of Death in New England } \\
\hline \multicolumn{3}{|l|}{ Epidemic diseases: } \\
\hline \multicolumn{3}{|l|}{ smallpox } \\
\hline \multicolumn{3}{|l|}{ diphtheria } \\
\hline \multicolumn{3}{|l|}{ pneumonia } \\
\hline \multicolumn{3}{|l|}{ measles } \\
\hline scarlet fever & \multicolumn{2}{|c|}{$\begin{array}{l}\text { killed } 30 \text { per } \mathrm{I}, 000 \text { during mid- } \\
\text { l8th century }\end{array}$} \\
\hline tuberculosis & \multicolumn{2}{|c|}{ killed 20 percent } \\
\hline \multicolumn{3}{|c|}{ Comparative Death Rates } \\
\hline Jamestown, after 1630 & \multicolumn{2}{|c|}{$40-50$ per thousand } \\
\hline French and English villages & \multicolumn{2}{|c|}{40 per thousand } \\
\hline New England & \multicolumn{2}{|c|}{ 24-26 per thousand } \\
\hline
\end{tabular}




\section{Maternal mortality}

1.5-2 percent death rate per pregnancy

\section{Average Life Expectancy at Age 20}

During the Seventeenth Century

\begin{tabular}{|l|l|}
\hline Married Women in Middlesex County, Virginia & 39 \\
\hline Married Men in Middlesex County, Virginia & 48 \\
\hline Women in Andover, Massachusetts & 62 \\
\hline Men in Andover, Massachusetts & 64 \\
\hline Women in Plymouth, Massachusetts & 62 \\
\hline Men in Plymouth, Massachusetts & 69 \\
\hline
\end{tabular}

\begin{tabular}{|l|r|r|r|}
\hline \multicolumn{4}{|c|}{ Growth of the Colonial Population } \\
\hline & North & South & Difference \\
\hline 1640 & 26,634 & 26,037 & 596 \\
\hline 1670 & 111,935 & 107,400 & 4,535 \\
\hline 1700 & 250,888 & 223,071 & 27,817 \\
\hline 1740 & 905,563 & 755,539 & 150,024 \\
\hline 1770 & $2,148,076$ & $1,688,254$ & 459,822 \\
\hline
\end{tabular}

\section{Questions To Think About}

1. How did life expectancy in the Northern and Chesapeake colonies compare? What implications might this have upon the nature of family life in the two regions?

2. What factors may have contributed to the discrepancy in life expectancy in the two regions?

3. Why might women have had a shorter life expectancy than men?

Declining Mortality, 1780-1820

\begin{tabular}{|l|l|l|}
\hline & $\mathbf{1 7 8 0}$ & $\mathbf{1 8 2 0}$ \\
\hline \begin{tabular}{l|l|}
\hline Northern states \\
Total population
\end{tabular} & 28 per thousand & 20 per thousand \\
\hline \hline Infants & $180-200$ per thousand & $\begin{array}{l}\text { 140-160 per } \\
\text { thousand }\end{array}$ \\
\hline \hline
\end{tabular}

Population Statistics 


\begin{tabular}{|c|c|}
\hline Population growth rate & 3.5 percent \\
\hline Doubling time & $20-25$ years \\
\hline $\begin{array}{l}\text { Average number of children per } \\
\text { family }\end{array}$ & 7-8 surviving children \\
\hline \multicolumn{2}{|c|}{ Marriage Rate } \\
\hline \multicolumn{2}{|c|}{ New England in the early 18th century } \\
\hline & men 98 percent \\
\hline & women 93 percent \\
\hline \multicolumn{2}{|l|}{ End of the I8th century } \\
\hline & women 78 percent \\
\hline
\end{tabular}

\begin{tabular}{|c|c|}
\hline \multicolumn{2}{|c|}{ Average age of marriage for women } \\
\hline & 20 \\
\hline \multicolumn{2}{|c|}{ Maryland 18} \\
\hline \multicolumn{2}{|c|}{$\begin{array}{l}\text { Declining Fertility } \\
\text { Proportion of families with } 6 \text { or more surviving children }\end{array}$} \\
\hline pre-1700 & 75 percent \\
\hline $1700 \mathrm{~s}$ & 67 \\
\hline $1800-30$ & 40 \\
\hline $1830-60$ & 20 \\
\hline $1860-1900$ & 10 \\
\hline
\end{tabular}

\section{Questions To Think About}

1. How does the growth of the colonial population compare to the growth of the American population today?

2. What were the major contributors to the growth of the colonial population?

3. What factors may have contributed to the decline in fertility after 1800 ? 


\section{POPULATION COMPARISONS}

Source: Taylor, Dale The Writer's Guide to Everyday Life in Colonial America: From 1607 - 1783 (Cincinnati: Writer’s Digest Books: 1997)

\begin{tabular}{|c|c|c|c|}
\hline REGION & 1688 & 1715 & 1765 \\
\hline CHESAPEAKE & 75,000 & 145,200 & 720,000 \\
\hline NEW ENGLAND & 75,000 & 162,150 & 600,000 \\
\hline MIDDLE & 42,000 & 99,300 & 580,000 \\
\hline DEEP SOUTH & 8,000 & 27,950 & 340,000 \\
\hline
\end{tabular}

Questions To Think About:

1. What region experienced the largest percentage of growth from 1688 to 1765 ? Why do you think that area grew so quickly?

2. What region experienced the smallest percentage of growth from 1688 to 1765 ? Why do you think that region did not grow as fast as the other regions? 


\section{APPENDIX C \\ COLONIAL HOUSING (DAY TWO)}

Plimouth Plantation Article

Pictures of Colonial Houses 


\section{Plimouth Plantation Article}

\section{A Good Roof Over Their Heads: The English Colonists Build Their Town}

Source: http://www.plimoth.org/learn/education/kids/homeworkHelp/building.asp\#col

Imagine arriving in a strange land after a long sea voyage. Imagine that it is the middle of winter and freezing cold. You are weak and tired from seasickness and just want a warm house on dry land. Now imagine that you have to build that house first!

This is what the English colonists (or "Pilgrims" as they are sometimes called today) had to do when they sailed to New England on the Mayflower in 1620. The colonists knew there were no English towns where they were going. They were prepared to build their own houses. But they were not prepared to build those houses in the middle of winter!

The colonists did not plan to arrive in Plymouth so late in the year. There were many delays, including a leaky ship Mayflower was supposed to travel with and a disagreement with the people who helped pay for the voyage. It took almost 2 months until they finally set sail for the last time. That was September 5, 1620. Mayflower didn't arrive in Plymouth until December.

Once the colonists arrived in Plymouth, they started to build their town right away. They had brought tools with them, and nails and iron hardware. The rest of what they needed the land had to provide. The men went to the woods and cut down trees. They used other axes to chop and trim the trees from round to square. Then they fit these pieces together so that they became a frame. This gave shape and strength to the house.

The colonists had thatched roofs on their houses to keep the sun, wind and rain out. To make them, they cut grasses and reeds from the marshes, and bundled and carried them back to their house. Then they fastened them in layers to the roof. To make the walls of the house, they built a framework of sticks called wattle within the house frame. They took clay, earth, and grasses and mixed them together with water to make a mortar called 
daub. They pushed the daub into the wattle until it filled the wall and made a smooth surface on the inside.

For the outside of the house, the colonists cut down trees and split the wood to make thin boards called clapboard. The clapboards were then nailed together over the frame of the house. It usually took between two and three months to make a house, from framing it, to covering it with clapboards, to making the wattle and daub, and then to thatching it. Work on the finishing touches sometimes went on for a few more months even after the family had started living inside of it.

When the houses were finished, they were not very large. Many only had one room. The colonists did their cooking, eating, and sleeping, as well as other work, in this room. The women cooked around a hearth, where small fires were lit. The fire from the hearth provided heat during the winter months. The fire also provided light at night. Candles and oil lamps were sometimes lit too. If there was a chimney, it was built of timber and clay and clapboards just like the rest of the house.

Most of the houses had only a few small windows that closed with a wooden shutter. The floors were hardpacked earth. Some houses had a storage space above the first floor, called a loft. These spaces were used to store food and other goods, like dried herbs from the garden, bundles of corn from the field, or even beds. They used ladders to climb up to the loft.

The English colonists had a very difficult time that first winter, as they were building their town. About half of the men, women and children who sailed on Mayflower died from sickness brought on by the cold and wet weather, not having a warm house to live in. However, they had built 11 new houses by the next winter. The town began to grow, and the colonists finally had a good roof over their heads. 
Colonial Houses

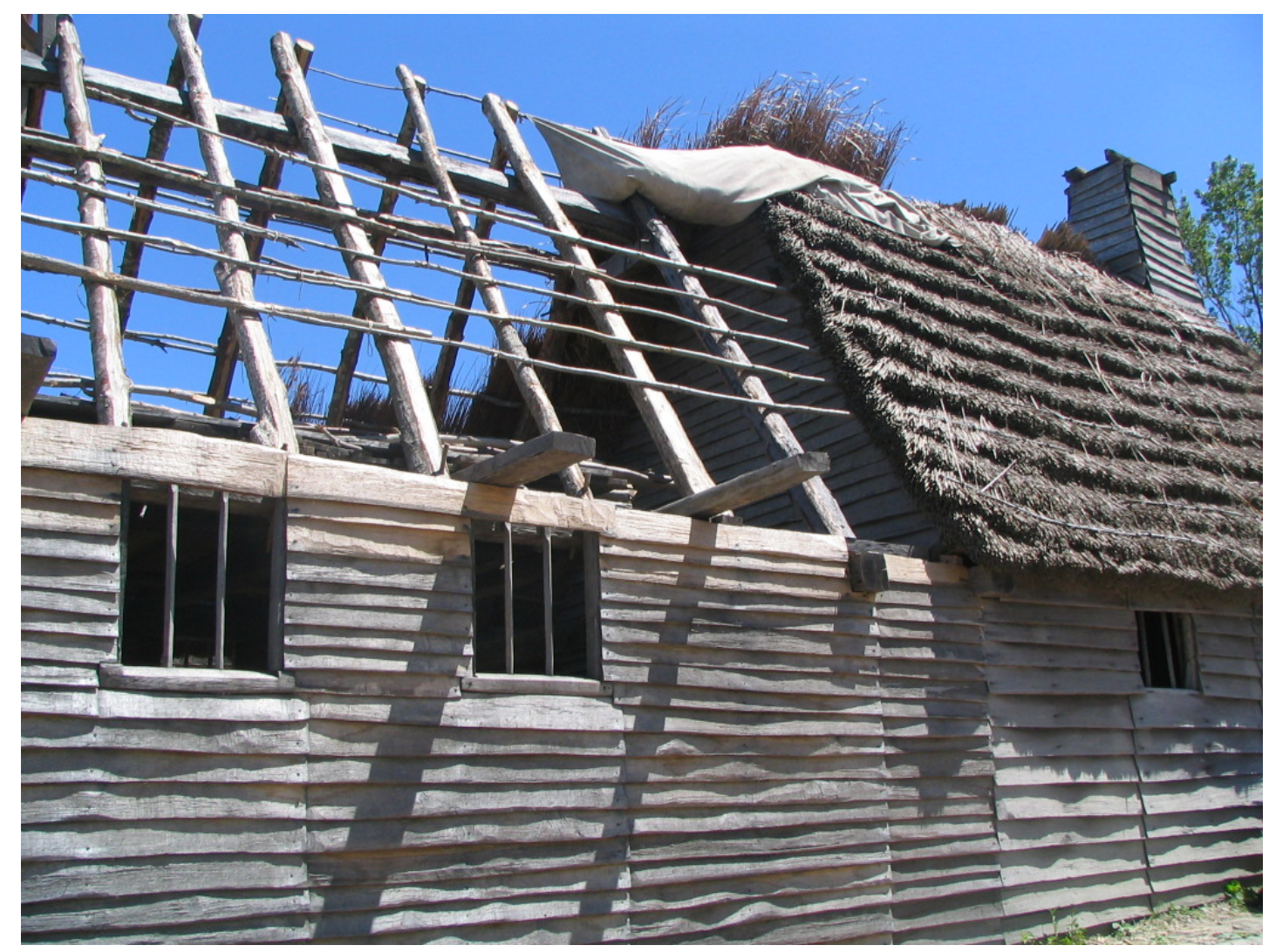

This is an addition in progress added to an existing colonial house. Notice the plank used for siding and the thatch roof construction. 
Southern plantation: Home of Thomas Jefferson
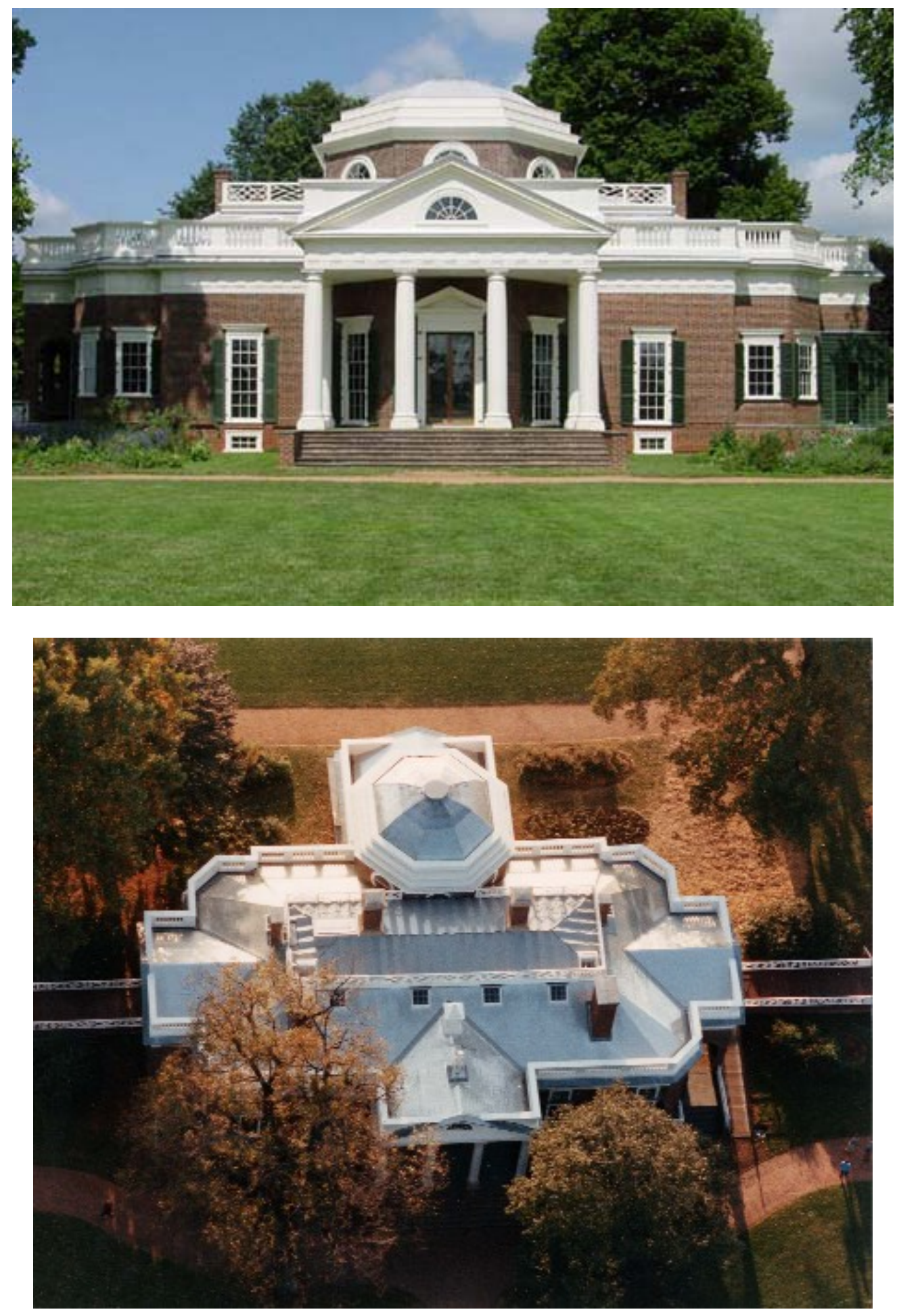


\title{
APPENDIX D \\ COLONIAL CLOTHING (DAY THREE)
}

\author{
Colonial Clothing - Age $1-7$ \\ Colonial Children's Clothing - Age 7 and up \\ Women's Clothing \\ Men's Clothing \\ Southern Plantation Clothing
}


Colonial Clothing - Age 1 - 7

Source: http://members.aol.com/calebj/clothing.html

\section{CHILDREN:}

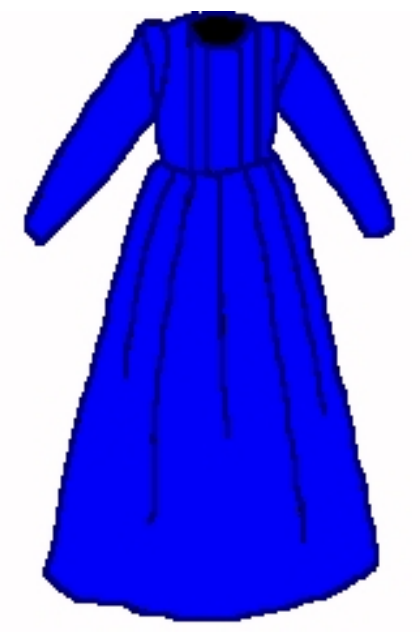

Young boys (to about age 8) and girls both wore dresses ("gowns"), generally made of either wool or linen. The skirt was full length, and the bodice was long sleeved and laced in the back, with a high neckline. The color blue was common for children--girls as well as boys--and other colors were common as well, such as grey, red, earthy greens, yellows, and browns.

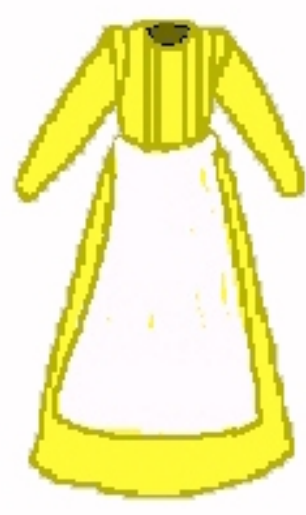

About the age of seven to nine, boys began to wear clothing similar to their fathers, and girls began to wear dresses cut more like those of their mothers. 
Colonial Children's Clothing - Age 7 and up

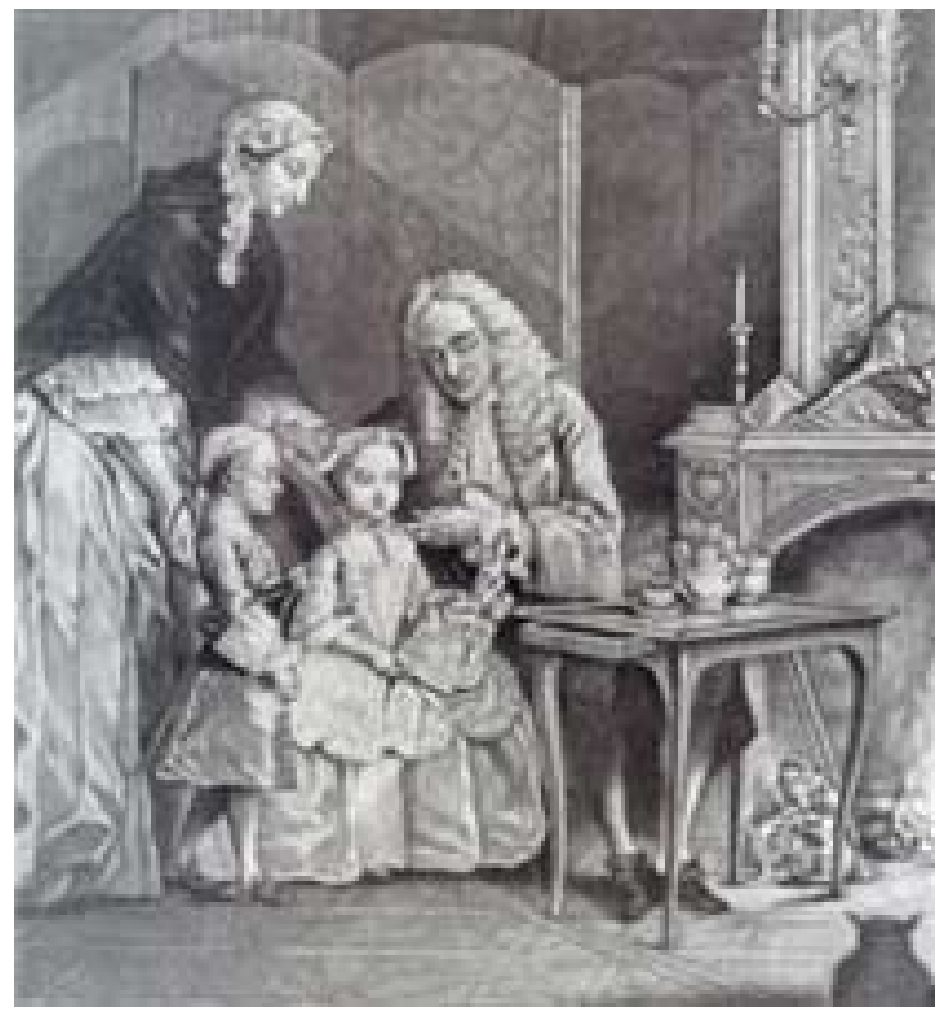

Wishing a Happy New Year to Grand Papa. Black and White mezzotint engraving. Printed for

John Bowles, London, 1745-1755. The children wear the formal adult-style clothing and have the posture expected of children during the first half of the eighteenth century; their mother wears a lappet cap and black hooded cloak.1941-250.

Source: http://www.history.org/history/clothing/children/child01.cfm 
Women’s Clothing

Source: http://members.aol.com/calebj/clothing.html

\section{WOMEN:}

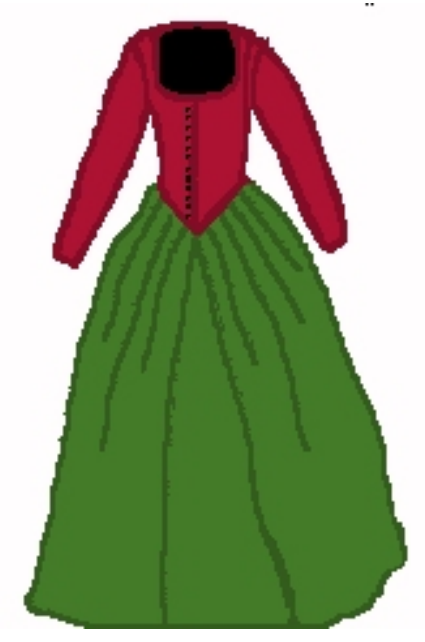

A woman's undergarment was a long off-white short-sleeved, linen shirt, resembling a modern-day woman's nightshirt except that it was ribbon-tied at the collar and cuffs and fastened in the front. One or more ankle-length, waistfastened petticoats were worn. The dress, or gown, consisted of two parts, a bodice and a skirt-sometimes the sleeves were a separate part as well, being tied to the bodice. The bodice or the skirt could be the same or different colors, and were made of wool.

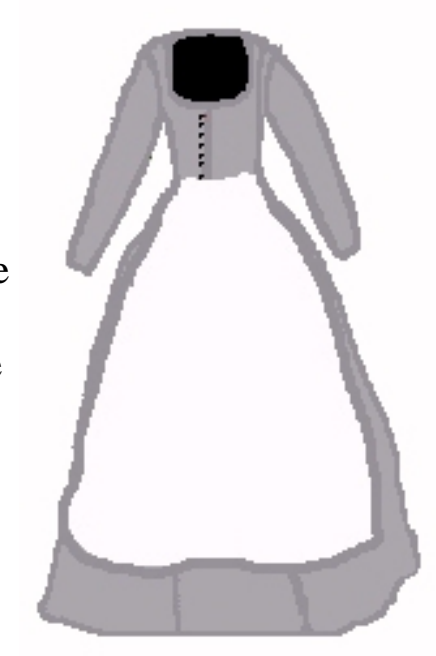
The bodice buttoned all the way down the front. The skirt was ankle-length and gathered at the waist. A long-sleeve fitted waistcoat was often worn over the top, and an apron was worn if the woman was doing any kind of work. Women occasionally wore lace collar and cuffs, and a cloak. Women's hair was always worn up and pulled tightly back, and worn under a coif (bonnet) or hat.

Common colors include red, earthy greens, browns, blues, violets, and grays. Contrary to popular myth, black and white clothing was clearly not the most common colors worn. An examination of the probate inventories of many early Plymouth women reveal a large variety of colors. Mary Ring, a long-time member of the Pilgrim's church in Leyden, and married to one of the more prominent members of the church, had her estate inventory taken in 1631. She had in her possession at that time: one waistcoat "of mingled color", two violet waistcoats, three blue aprons, two white aprons, one black apron, a red petticoat, a violet petticoat, white stockings, blue stockings, and also had some red cloth, grey cloth, and blue cloth ready for sewing. Desire (Gorham) Howland, daughter of Mayflower passenger John Howland, had a green apron, red stockings, white apron, and black cloak in her estate inventory. 
Men’s Clothing

Source: http://members.aol.com/calebj/clothing.html

\section{MEN:}

For the upper body, men usually wore a long, short-sleeved, off-white linen shirt, with collar. On top of that he wore a doublet, which was relatively close-fitting, with long sleeves, broad padded shoulders, and buttoned down the front with tabs at waist. A cloak was often draped over the shoulders. A lace collar and cuffs were worn, as was a felt hat or cap. Older or more revered men often wore over the top of everything a fulllength wool gown similar to a modern-day bathrobe.

For the lower body, breeches were usually worn. Breeches are front-buttoning pants which extend to the knee level, and were relatively baggy. Stockings were knee-length, and resemble modern-day women's opaque tights. Shoes were generally low-heel, low cut leather shoes.

Whites, beiges, blacks, earthy greens, and browns were the predominant colors in men's clothing. Contrary to popular stereotype, buckles were not worn on hats, shoes, belts, or anywhere else, nor was black the predominant color except for on Sunday or formal occasions. From the probate inventories of Plymouth Colony, we learn that Governor William Bradford had a green gown, violet cloak, lead colored suit with silver buttons, and a red waistcoat. Elder William Brewster had green drawers, a red cap, a violet coat, and a blue suit. And Mayflower passenger John Howland had a red waistcoat listed in his inventory. 
Southern Colonial Clothing

Source: http://www.jamestowne.org/Fashion.htm

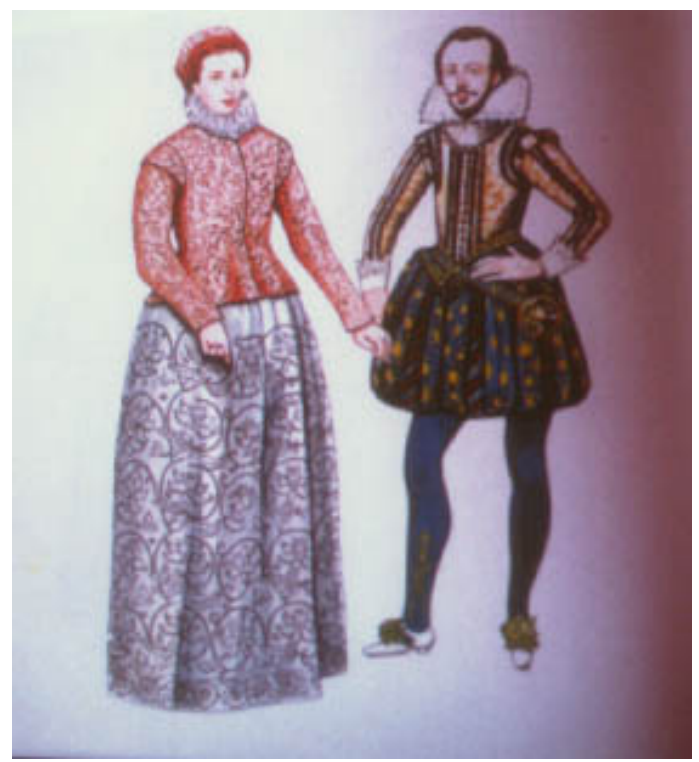

Jamestown - early 1600’s

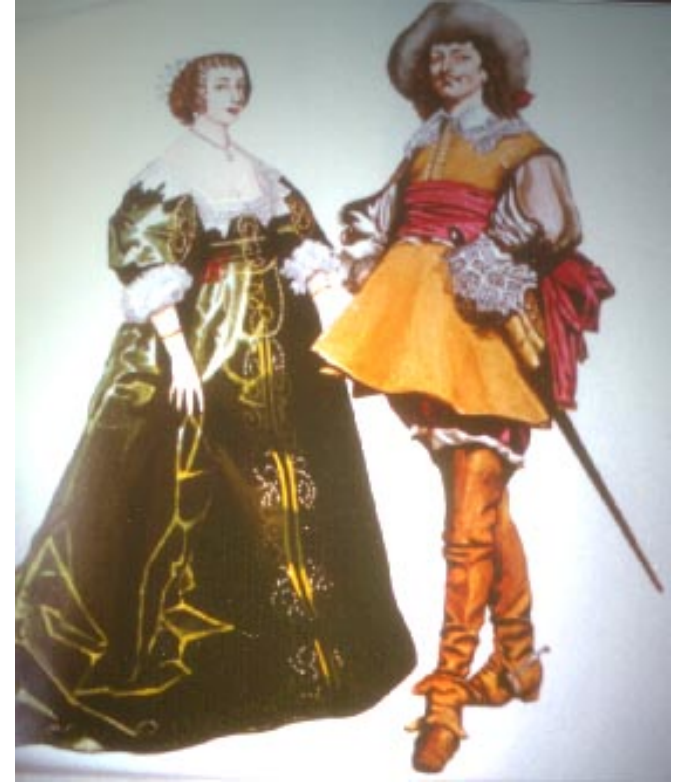

Jamestown - mid 1600’s

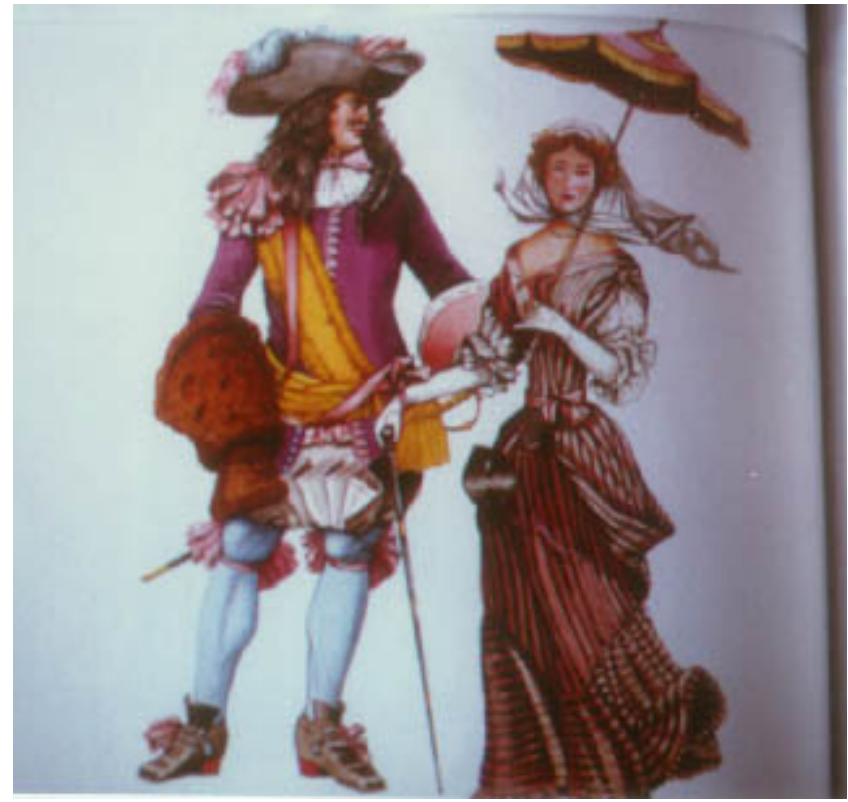

Jamestown - late 1600’s 


\title{
APPENDIX E
}

COLONIAL GAMES (DAY FOUR)

\author{
Stool Ball \\ Hop-Round \\ Hoop Toss \\ Nine Pins \\ Ball and Cup \\ Fox and Geese
}


Colonial Game: Stool Ball

Materials needed: One stool turned upside down and a ball.

Background: Many think that stoolball was the predecessor to games such as cricket, baseball and rounders. It originated in England and was brought to the New World with the colonists.

How the game is played: Children form a circle approximately 15 to 20 ' wide. In the center, place the stool. One student is chosen to be the initial Conqueror. This person must bat the ball away and defend the stool from getting hit with the ball. The ball is given to one student in the circle who can either try to hit the stool or can secretly pass the ball on to another student. To add a variation, have students form two circles (one within the other) and have each circle move in opposite directions, secretly passing the ball (or balls) to each other to confuse the Conqueror as to who has the ball (s). If you add an additional ball, add an additional Conqueror in the middle. When a student successfully hits the stool, they trade places with the Conqueror. 
Colonial Game: Hop-Round

Materials needed: Chalk to draw the pattern on the pavement and five stones per player. Background: This game dates back centuries to ancient England, perhaps from Roman soldiers who invaded Great Britain.

How the game is played: Draw the following diagram:

Hop-Round diagram:

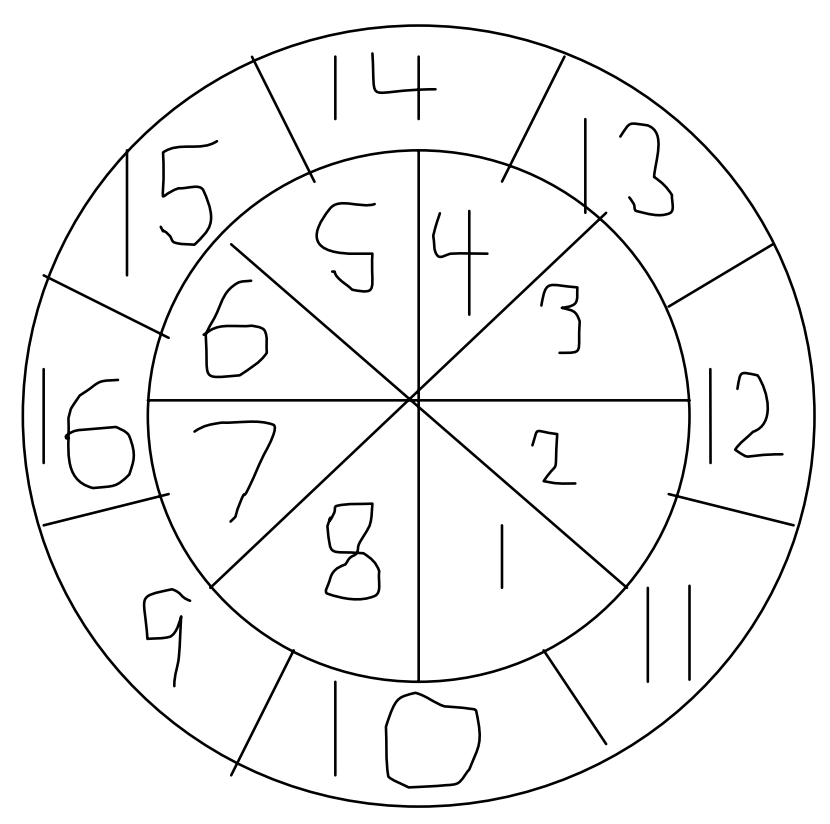

First, players should decide what score wins. The first player throws all five of his/her stones into the pattern either one at a time or all at once. If the player successfully hops into and out of the pattern, that players' score will be the total of all of numbers the stones have landed on. Any stones that land on a line do not count. After the potential score is tallied up, the player hops through the pattern on one foot, picking up a stone 
whenever he/she lands in a space with a stone. After the first stone is picked up, players must only hop to spaces with their stones in it. If after the first stone they hop to a space which does not have their stone or places the second foot down, their turn is done and they score zero. If the player successfully hops through the pattern, the player can claim any space by writing his/her initials on it and receives the previously tallied potential score. The next player must hop over the “claimed” space when picking up his/her stones. The first player to reach the agreed upon score wins. 
Colonial game: Hoop Toss

Materials Needed: Hula hoop, small stick and 5 small balls

Background: Colonial children rolled the metal circle from a wagon wheel to play this game.

How the game is played: One player rolls the hula hoop using a stick on the inside of the hoop to keep it moving. Other players take turns trying to throw their ball through the hoop. The first player to throw their ball through the hoop five times wins. The faster the hoop is rolled and the farther away the players with the balls are, the more difficult the game is to play. 
Colonial game: Nine Pins

Materials Needed: Nine wooden pins (cone shaped), 1 ball

Background: Nine pins was a common colonial game, especially in the Southern colonies where a spot of green grass would be set aside near the court house or a large Southern plantation just for a game of nine pins. It is similar to the popular game of bowling.

How to play the game: Set up the pins in three rows of three as seen in the following illustration:

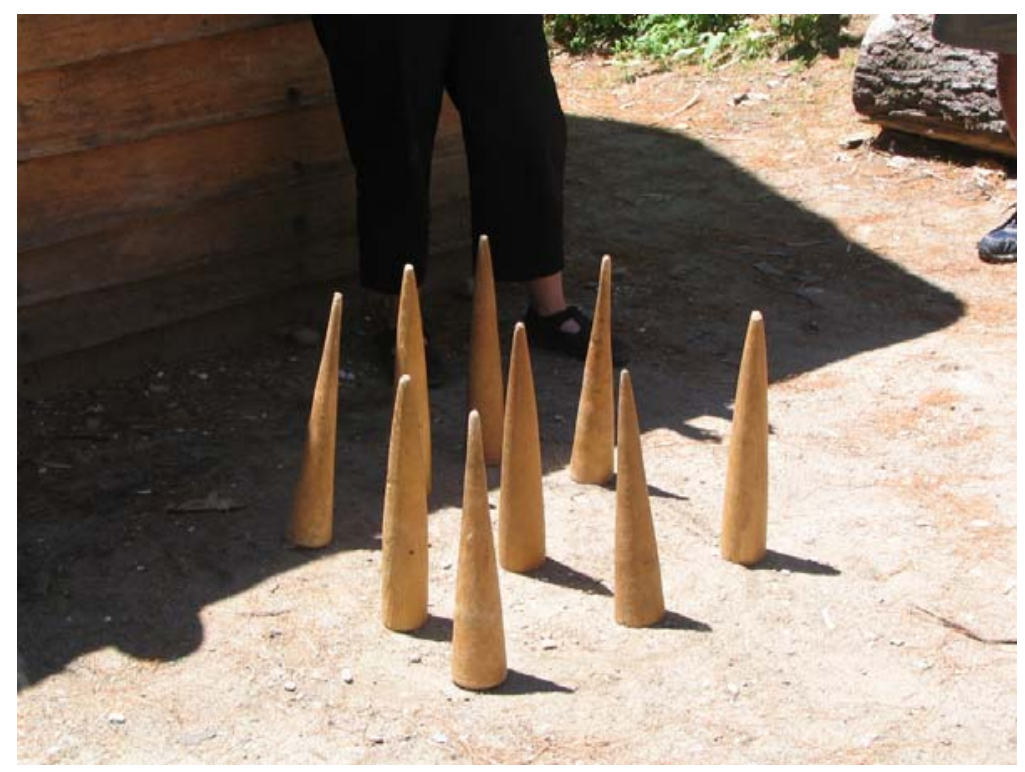

Players take turns rolling the ball at the pins. The player's score is the total number of pins knocked over. The first person to reach an agreed upon total score wins. 
Colonial game: Ball and Cup

Materials needed: Ball and cup attached with string (see illustration below)

Background:

How to play the game: Players swing the ball up into the air trying to catch the ball in the cup.

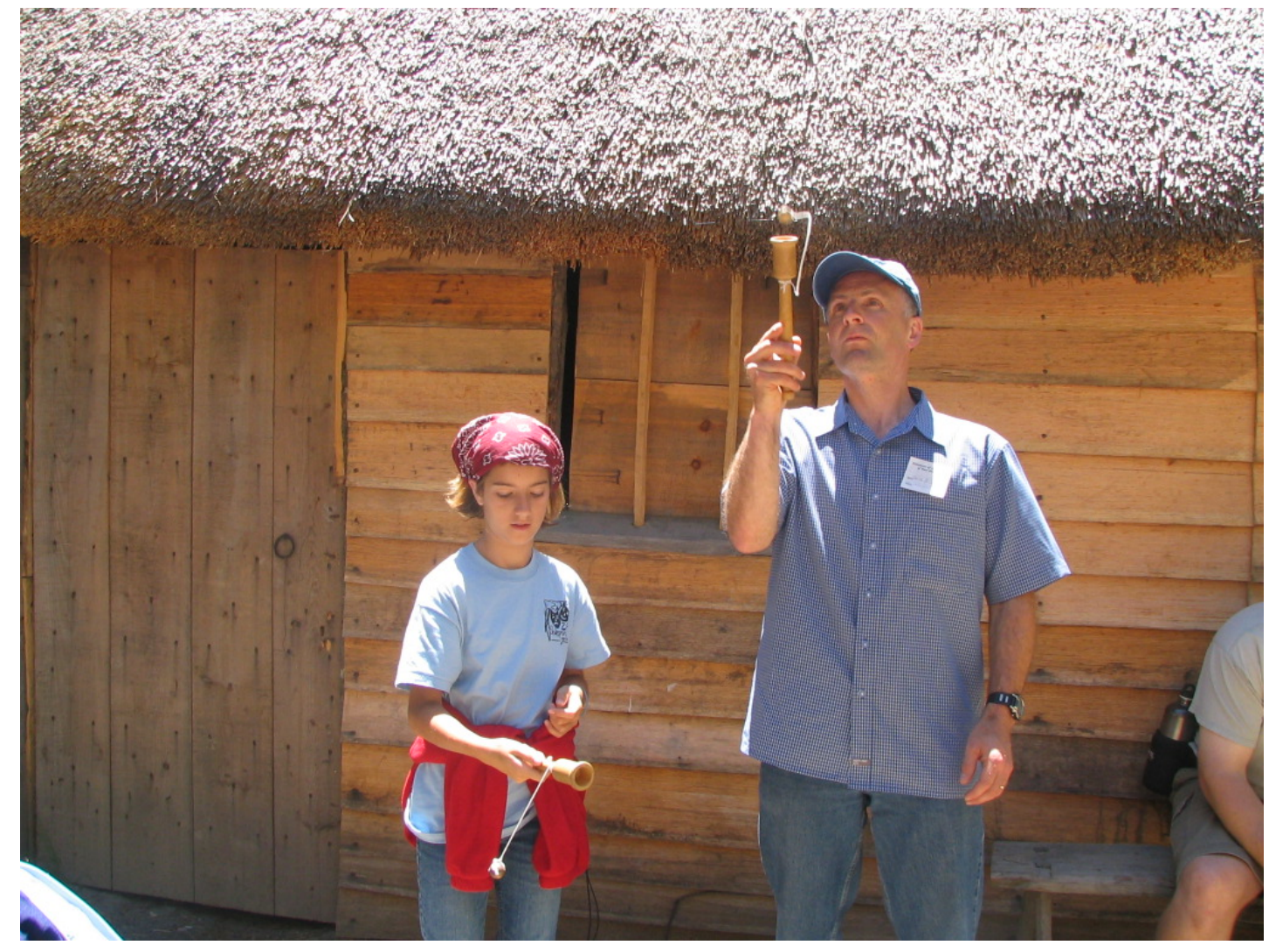




\section{Colonial game: Fox and Geese}

\section{Colonial Make-it-at-Home Activity}
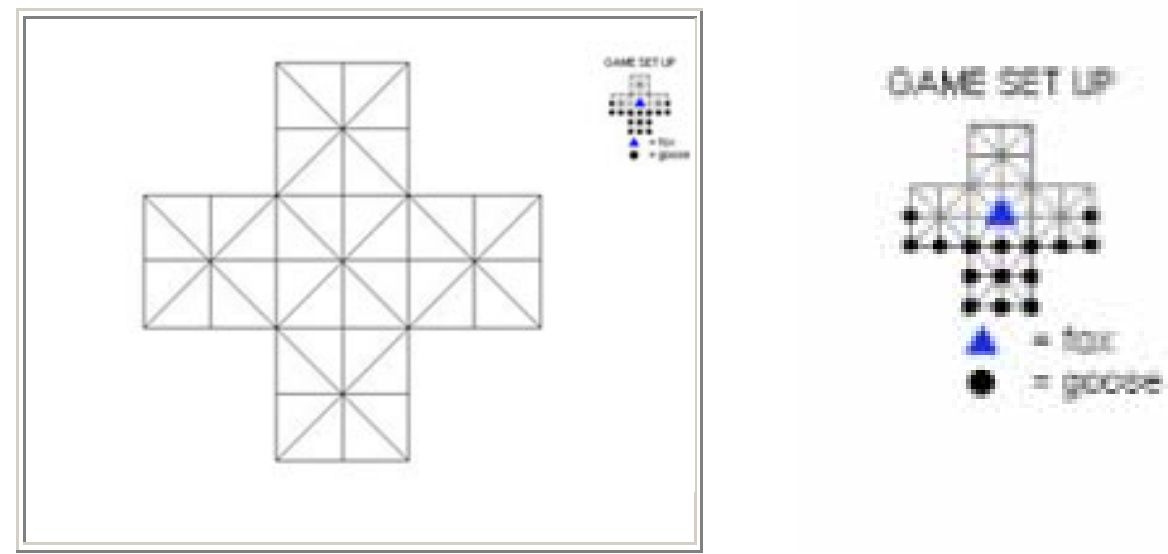

The Game of Fox and Geese

This game was very popular in the 17th century. It takes a lot of skill to win. Good luck!

Number of Players: 2

Equipment Needed: 15 geese (use something small for the geese, like small stones, buttons, or dried corn, beans, etc.)

1 Fox (this piece must look different from the geese)

Setting up: To make your Fox and Geese board you may print and use the game board

provided above or, if you'd like to play outside, draw the game board into the sand using a stick. Use the game set up diagram, also provided below, to set up your pieces for the start of the game.

Rules: For the geese to win they must corner the fox so that he can't eat them. For the fox to win this game he must eat all the geese. The fox knows he has won if there aren't enough geese on the board to cover him. To begin the game, place the fox and geese on the board as shown in the game set up diagram. Decide who will start first. The pieces move along the lines only moving one space at a time. The fox can move in any direction while the geese can only move forward or sideward. The fox captures the geese by jumping over them to an empty space, just like jumping in checkers. Any goose that the fox jumps is taken off the board. The geese do not jump the fox, but move along the lines trying to corner the fox so that he cannot move.

Source: http://www.plimoth.org/learn/education/kids/make.asp\#col 


\title{
APPENDIX F
}

COLONIAL WORK - TODDLERS TO AGE SEVEN (DAY FIVE)

\author{
Northern Colony Rules \\ Sampler Alphabet
}


Northern Colony rules

1. To pray as soon as they awake in the morning \& going to bed at night.

2. To make a bow or Curtesy when they see their Superiours first in a Morning, \& when going to bed at night, \& when they give or take anything from them, \& when prayers are done in the family \&c.

3. Not to speak when others are speaking, nor talk too much or all at one, nor speak before they think.

4. Not to behave themselves aukwardly or untowardly by Gaping, Staring \&c.

5. Not to repeat what others say, or stand listening when they have other business to mind.

6. Not to Contend or fight with one another.

7. To keep themselves neat \& clean, \& to be so in everything.

8. Not to seat themselves first at the Table nor to stand between others \& the fire, or put things out of their places.

9. Not to stay too long when sent on an Errand or desert the business \& Duty required of them.

10. To use proper Titles \& terms to men \& Women.

11. To stand up at Craving a Blessing \& returning thanks, \& to behave themselves decently in all other parts of divine Worship \& at all other times.

Source: Memoirs of Josiah Cotton, Mass. His.Soc., pp. 160, 167-68. As repeated in James Axtell’s The School Upon a Hill. 
Sampler Alphabet

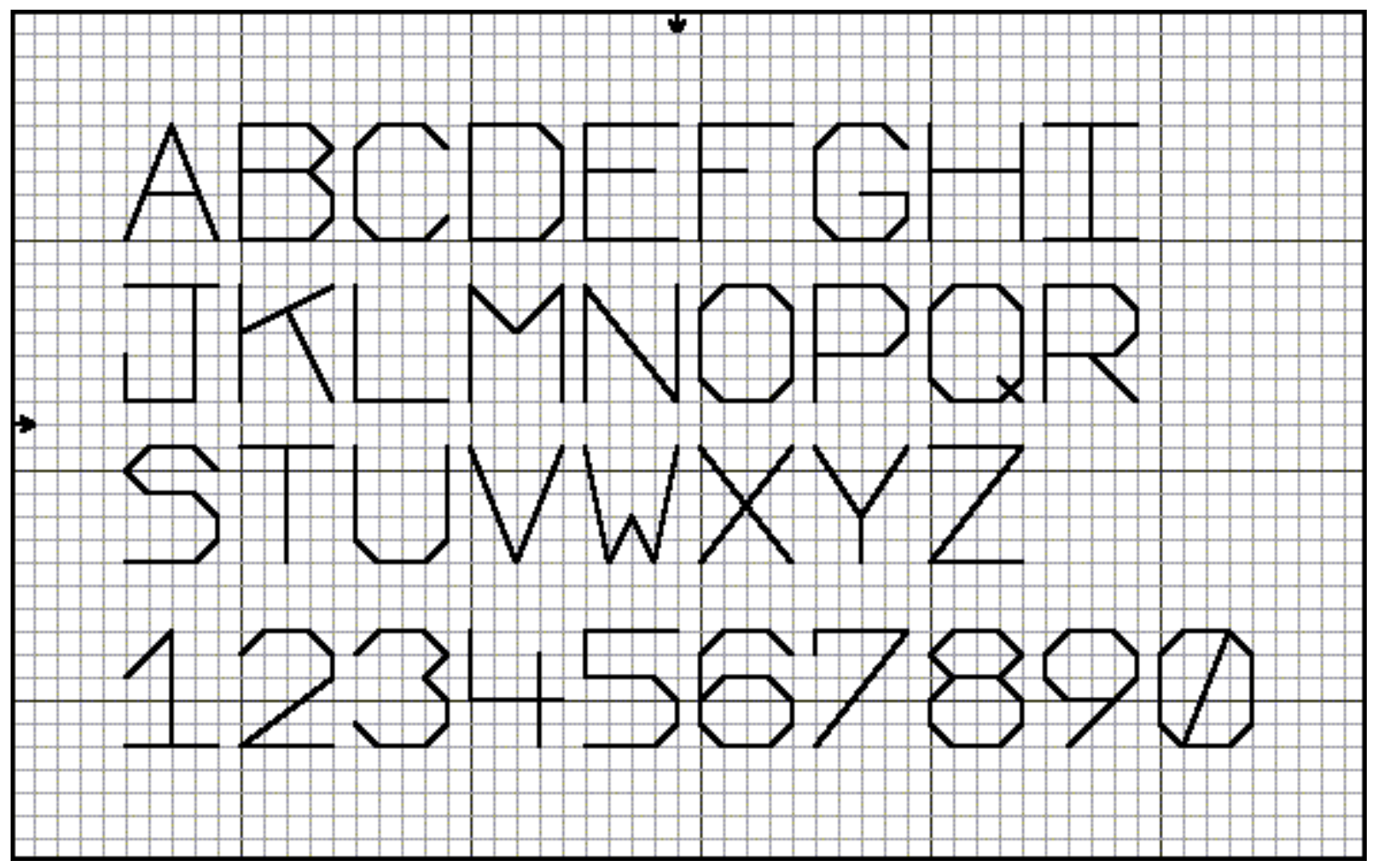

Source: http://crossstitch.about.com/library/graphics/backstitch_alphabet.gif 


\section{APPENDIX G \\ COLONIAL WORK -AGE SEVEN TO ADULT (DAY SIX)}

Miniature Adulthood: Women

Men

Sample Indenture Agreement

Fill-in-the-blank Indenture Agreement

Story of Benjamin Franklin 
Miniature Adulthood: Ages 7-21

Women

Source: http://pivot.mit.edu:8080/mfh/view-node.jsp?nid=32

\section{Early Childhood}

In 1630, when you are only three years old, you leave your home in England and travel across the ocean with your widowed father and his two sisters to join the new Plymouth Colony in Massachusetts.

You are too little to remember much about the three months you spend at sea, but you do remember your first house. You have never seen anything like it. It is a two-room, thatched wattle and daub house in a brand-new village, a day's ride from the colony's "capital" at New Plymouth.

You also remember the day your father got married. Your stepmother is the daughter of one of the families that came from Holland when the colony was first established in the early 1620s. She is not unkind to you, but she is soon busy with three children of her own.

You have few responsibilities in the household until you turn six. Then it is time for you to begin learning what you will need to know as an adult woman. There are not yet any schools in the colony; your parents will teach you to read the Bible. Many people think that it is better to be educated by adults who are not as close to you emotionally as your own mother and father, so parents often send their children to live with another family: girls to learn huswifery and boys farming or a trade.

\section{Yow next choice is:}

1. Your parents choose for you to remain at home in Scituate, where your stepmother will teach you huswifery (you will learn the duties of a housewife, which included cooking, cleaning, making and mending clothes, tending the family's gardens, rearing children, nursing the sick.)

2. Your parents choose for you to move to Plymouth village to live with the Widow Fuller, who recently lost her husband. She nurses women during childbirth. You can help her and she can teach you her trade.

3. Your parents choose for you to move to the household of Elder William Brewster, one of the most important men in the colony. 


\section{Apprenticeship Options for Boys}

Source for many definitions below::

http://www.history.org/Almanack/life/trades/tradehdr.cfm

1. Apothecary - In colonial times, the apothecary was more than simply a druggist. An apothecary often: provided medical treatment, prescribed medicine, trained apprentices, performed surgery, served as man-midwives

2. Basketmaker - basketmaking requires an ax, a few wedges, a large knife, and a supply of saplings.

3. Blacksmith- Blacksmiths fashioned items from iron and steel for the their fellow tradesmen to use in their work and also made things for household use.

4. Bookbinder - Manually bound books by preparing leather covers and stitching pages

5. Brickmaker - created new bricks as well as repaired old bricks

6. Cabinetmaker - cut wood and joined it to create cabinets

7. Carpenter - the main business of the colonial carpenter was to cut and join timber and board into sturdy wooden homes and shops.

8. Clergy - Clergy, or pastors, required religious education, rather than apprenticeship, which was generally completed around age 21 .

9. Cooper - Coopers crafted casks which held flour, gunpowder, tobacco, and other commodities, served as shipping containers, stored liquids from wine to milk

10. Farmer - Farmers till the soil, plant the seed, tend and harvest crops.

11. Founder - Founders melted both brass and bronze and poured them into molds to form andirons, bells, coach and harness fittings, shoe buckles, sword hilts, furniture hardware, and many other things.

12. Harnessmaker - crafted leather and metal to create horse harnesses.

13. Gunsmith - because most guns in Colonial America were imported from Europe, the Gunsmith was responsible for repairing firearms.

14. Miller - responsible for milling the farmers grain; usually done with the assistance of a windmill.

15. Printer - uses mirror image metal letters set to the words of the story to print newspapers and books.

16. Shoemaker - using leather, the Shoemaker custom-made every shoe and boot.

17. Tailor - measures customer and cuts fabric to produce custom made clothing.

18. Weaver - dyed wool and cotton and wove the threads to produce fabric.

19. Wheelwright - cut wood and bound it with metal to create wagon wheels

20. Wigmaker - the Wigmaker wove animal or human hair to produce wigs in style with England fashions for men. 


\section{Sample Indenture Agreement \\ Source: http://hometown.aol.com/ntgen/hrtg/indenture.html}

This indenture witnesseth, that Joseph Lynde, Tho Wait, John Dexter, Stephen Pain, and Joseph Wilson Select-men, Overseers of the Poor of the Town of Maldon in the County of Middlesex in New-England by and with the Consent of two of his majesties Justices of the Peace for said County have placed and by these presents do place and bind out John Ramsdell a poor Child belonging to Maldon aforesaid unto Edward Wait of Maldon in the County of Middlesex yeoman, and to his Wife and Heirs, and with them after the manner of an Apprentice to dwell and Serve, from the Day of the Date of these Presents until the fifth Day of April, which will be in the Year of our Lord one Thousand Seven Hundred and Sixty two at which time the said Apprentice if living will arrive at the age of twenty one Years, during all which said time or term the said Apprentice:

his said Master and Mistress well and faithfully shall Serve, their Secrets he shall keep close, their Commandments lawful and honest everywhere he shall gladly obey, he shall do no Damage to his master nor suffer it to be done by others without letting or giving Seasonable notice thereof to his Master; he shall not waste the Goods of his said Master nor lend them unlawfully to any; at Cards, Dice or any other unlawful game or Games he shall not play; ...; Matrimony he shall not contract; Tavern, Ale Houses or places of Gaming he shall not haunt or frequent; From the Service of his Master by Day nor Night he shall not absent himself; but in all things and at all times he shall carry and behave himself towards his Master and all theirs, as a good and faithful Apprentice ought to do to his utmost Ability during all the Time or term aforesaid.

And the said Master doth hereby covenant and agree for himself his Wife and heirs to teach or cause the Apprentice to be taught the Art and mystery of a Cordwainer and also to read write and cypher, and also shall and will well and truly find allow unto and provide for the Apprentice Sufficient and wholesome meat and Drink, with Washing, Lodging and apparrel, and other Necessaries meet and convenient for Such an Apprentice during all the time or term aforesaid. And at the End and Expiration thereof shall dismiss the Apprentice with two good Suits of Apparrel for all parts of his Body one for LordsDays, the other for working Days, Suitable to his Quality. In Testimony whereof the Parties have to these Indentures interchangeably Set their Hands and Seals the thirtieth day of April, in the twenty first year of the Reign of our Sovereign Lord George, the Second King of Great Britain. Anno Domini one thousand seven hundred and forty eight. Signed, Sealed and Delivered in presence of:

John Shute John Wilson Edward Wait

Source: Original document: Green Family Papers, New England Historic Genealogical Society. Transcribed from: History of Malden, Mass, 1633-1785, Deloraine Pendre Corey, 1899 
This indenture witnesseth, that \{Father's Name $\}$ of the Town of \{town name $\}$ in the County of \{County name\} in \{Colony name\} by and with the Consent of two of his majesties Justices of the Peace for said County have placed and by these presents do place and bind out \{Student's name\} a Child belonging to aforesaid, and to his Wife and Heirs, and with them after the manner of an Apprentice to dwell and Serve, from the Day of the Date of these Presents until the fifth Day of April, which will be in the Year of our Lord one Thousand Sixteen Hundred and Seventy two at which time the said Apprentice if living will arrive at the age of twenty one Years, during all which said time or term the said Apprentice:

his said Master and Mistress well and faithfully shall Serve, their Secrets he shall keep close, their Commandments lawful and honest everywhere he shall gladly obey, he shall do no Damage to his master nor suffer it to be done by others without letting or giving Seasonable notice thereof to his Master; he shall not waste the Goods of his said Master nor lend them unlawfully to any; at Cards, Dice or any other unlawful game or Games he shall not play; Matrimony he shall not contract; Tavern, Ale Houses or places of Gaming he shall not haunt or frequent; From the Service of his Master by Day nor Night he shall not absent himself; but in all things and at all times he shall carry and behave himself towards his Master and all theirs, as a good and faithful Apprentice ought to do to his utmost Ability during all the Time or term aforesaid.

And the said Master doth hereby covenant and agree for himself his Wife and heirs to teach or cause the Apprentice to be taught the Art and mystery of a Cordwainer and also to read write and cypher, and also shall and will well and truly find allow unto and provide for the Apprentice Sufficient and wholesome meat and Drink, with Washing, Lodging and apparrel, and other Necessaries meet and convenient for Such an Apprentice during all the time or term aforesaid. And at the End and Expiration thereof shall dismiss the Apprentice with two good Suits of Apparrel for all parts of his Body one for LordsDays, the other for working Days, Suitable to his Quality. In Testimony whereof the Parties have to these Indentures interchangeably Set their Hands and Seals the thirtieth day of April, in the twenty first year of the Reign of our Sovereign Lord George, the Second King of Great Britain. Anno Domini one thousand sixteen hundred and fiftyeight.

Signed, Sealed and Delivered in presence of:

\{Teacher's name\} 
The Story of Benjamin Franklin

Source: http://www.colonialhall.com/franklin/franklin.php

Benjamin Franklin was born at Boston, on the 17th of January, 1706. His ancestors were from the county of Northampton, in England, where they had for many generations possessed a small freehold estate, near the village of Eaton. During the persecutions in the reign of Charles II., against the puritans, the father of Benjamin, who was of that persuasion, emigrated to America, and settling in Boston, had recourse for a livelihood to the business of a chandler and soap boiler. His mother's name was Folger. She was a native of Boston, and belonged to a respectable family

At an early age, young Franklin discovered, as his parents thought, a more than ordinary genius; and they resolved to give him an education, with reference to the profession of a clergyman. Accordingly, he was placed at a grammar school, where he soon attained the reputation of a lad of industrious habits, and respectable genius.

His parents, however, at the expiration of a year, found that their slender revenues would not admit of the expense of collegiate instruction. He was, therefore, soon after taken home to prosecute the business of his father. In this occupation he was employed for two years, but it was ill adapted to his constitution, and he felt unwilling to continue cutting wicks for candles, filling moulds, and running of errands. He became uneasy, and at length resolved to embark on a seafaring life. To such a proposition, however, his parents strongly objected, as they had already lost a son at sea. He was permitted, however, to change his business, and allowed to choose an occupation which was more congenial to his inclinations.

His fondness for books had, from an early age, been singularly great. He read every thing within his reach. His father's library was itself scanty, being confined to a few such works as Defoe's Essay upon Projects, Mather's Essay on doing Good, and the Lives of Plutarch. These he perused with great attention, and they appear to have exercised a favorable influence on his mind. His love of books was frequently noticed by his father, who, at length, proposed to bind him as an apprentice to an elder brother, who was at that time a printer of a newspaper in Boston. He was accordingly thus situated, in the year 1717, when he was scarcely twelve years of age. He soon became a proficient in the mechanical part of the business, and seized every opportunity for reading books that he could borrow from his acquaintance, in which employment he spent the greater part of his nights. He soon began to indulge himself in writing ballads and other poetical pieces; but, it is said, that his father speedily satisfied him that this was not the species of composition in which he could excel. His next efforts were directed to prose composition, in which his success is well known, and duly appreciated. With a passion for reading and writing, he imbibed a kindred one for disputation; and adopting the Socratic method, he became dexterous in 
confuting and confounding an antagonist, by a series of questions. This course gave him a skeptical turn with regard to religion, and while he was young he took every opportunity of propagating his tenets, and with the ordinary zeal of a new convert. He was, however, soon convinced, by the effect produced on some of his companions, that it was extremely dangerous to loosen the ties of religion, without the probability of substituting other principles equally efficacious. The doubts which subsisted in his own mind, he was never able to remove; but he was not deficient in fortifying himself with such moral principles as directed him to the most valuable ends, by honorable means. By habits of self-denial, early formed, he obtained a complete dominion over his appetites, so that, at the age of sixteen, he readily discarded animal food, from the conviction produced in his mind by perusing a work on the subject, that he should enjoy a more vigorous state of health without it. He now offered his brother to maintain himself, for half the sum paid for his board; and even with this he was able to make savings to purchase what books he wanted. In his brother, he found a harsh master, and Benjamin felt indignant at the treatment which he experienced from him in the way of business. His brother had established a newspaper, in which the apprentice contrived to insert some papers and essays anonymously. These were read and highly commended by people of the best judgment and taste in the town. The young man began now to feel his importance, which was still more impressed on him by having the paper published in his own name, that of his brother, for some political offence, having been interdicted by the state. 
APPENDIX $\mathrm{H}$

COLONIAL SCHOOL (DAY SEVEN)

Picture of a Hornbook 
A Hornbook

Source: http://www.iupui.edu/ engwft/hornbook.html

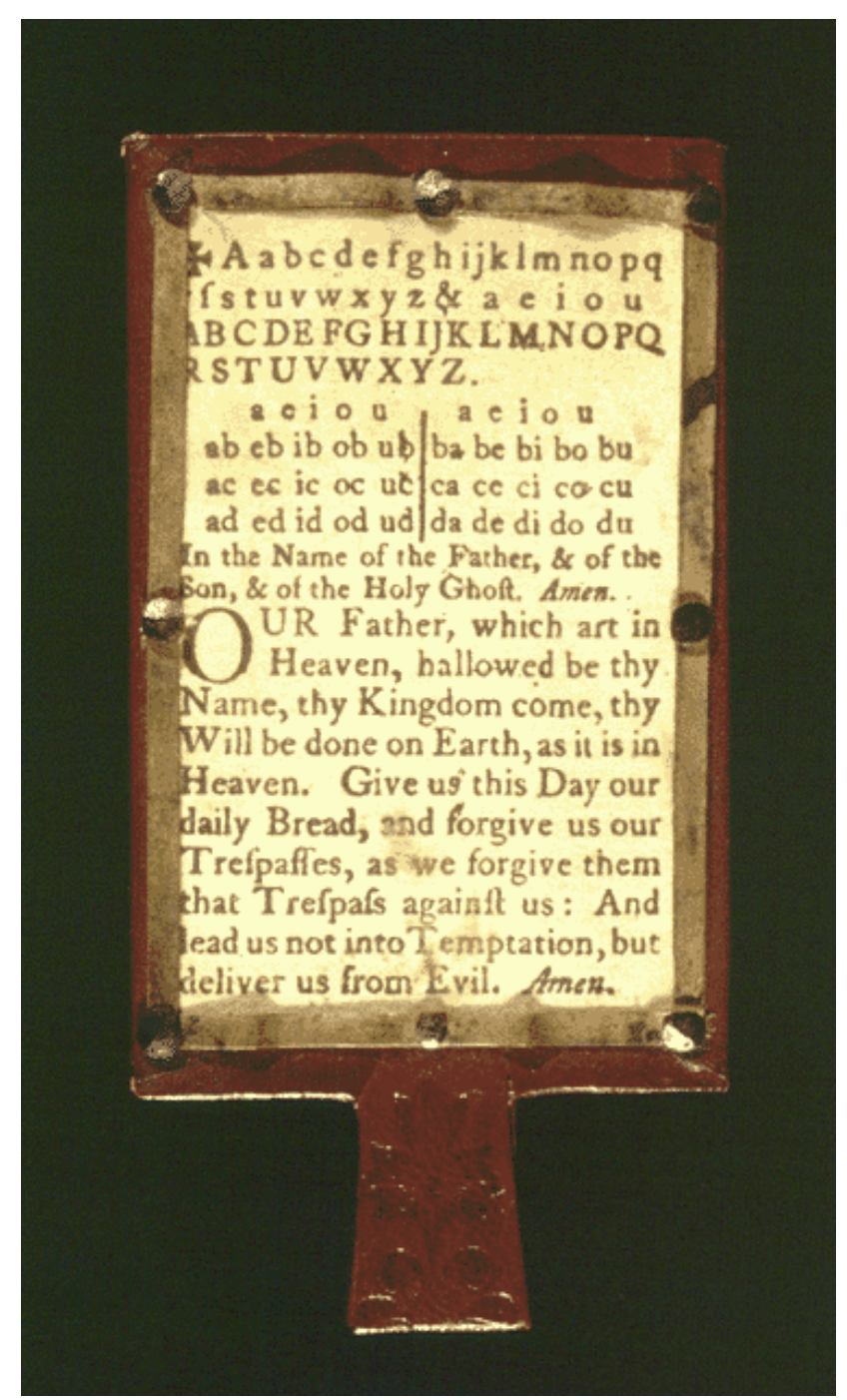

A typical hornbook text measuring about $31 / 2 "$ x 2 1/2." 
Hornbook Template

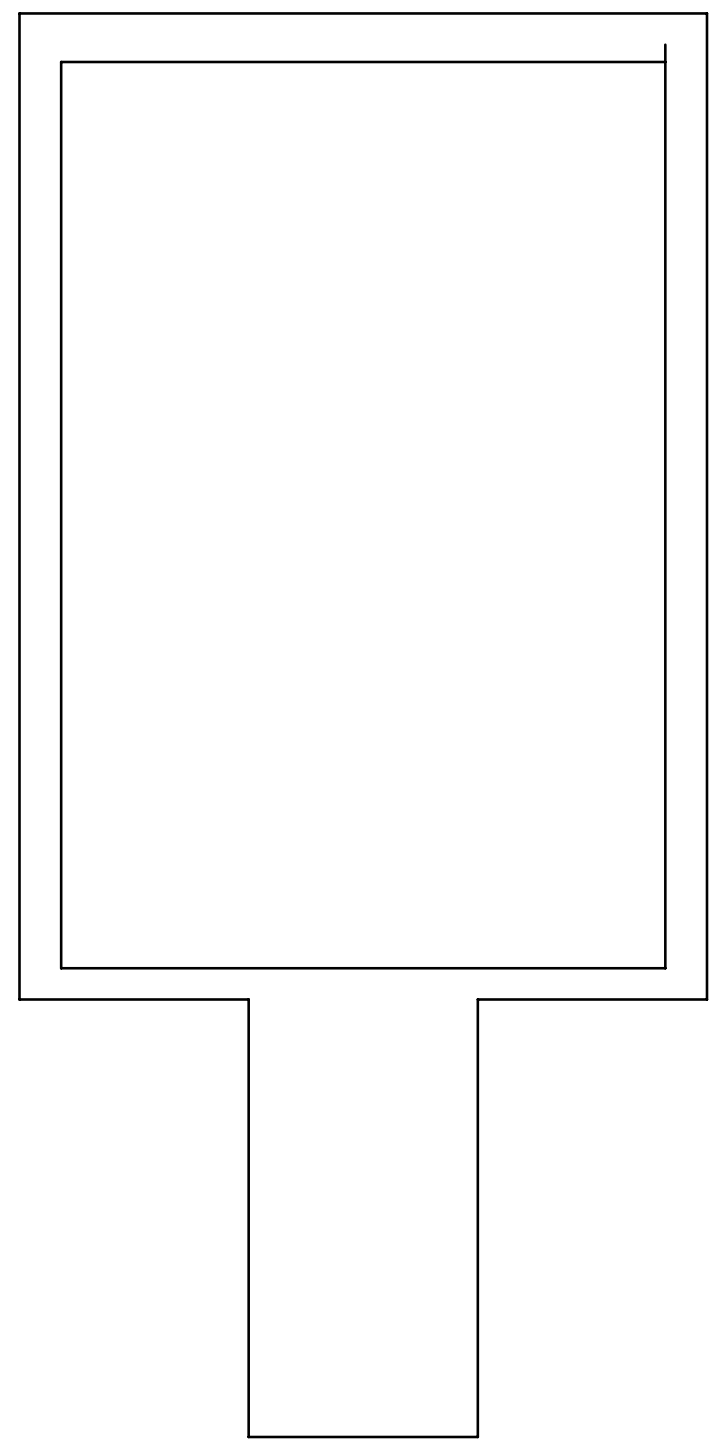

Cut parchment paper size of inside template. Cut cardboard size of outside template. 
APPENDIX I

COLONIAL CHURCH (DAY EIGHT)

Northern Sermon

Southern Sermon 
Northern Sermon

The Duties of Children to their Parents
by Cotton Mather

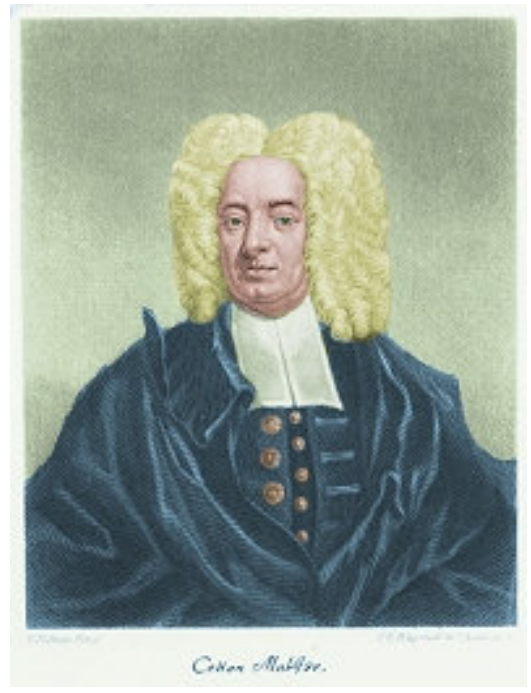

Source: http://www.spurgeon.org/ phil/mather/dut-chi.htm

DEUT. 27:14, 16

The Levites shall speak, and shall say unto all the

Men of Israel, with a loud voice:

Cursed is he that setteth Light,

By his Father or his Mother.

And All the people shall say, Amen.

I am going to Entertain you with a Discourse, that cannot have a fitter preface, than those words in Psalm 34.11: Come, ye Children; Hearken unto me, I will teach you the Fear of the Lord. The Children of my Neighbors are now appearing among us. Yea, Our Little Ones are no Little part of the Assembly. And very many of these are the Children of Pious Parents, the Children whose Piety has therefore been fervently desired and required by their Parents. Come, Ye Children, Hearken to me; I will tell you, what you shall do, that your Parents may be Happy in you, and that your own Happiness may be secured and increased.

There was a Solemnity sometimes observed upon the Two Mountains of Ebal and Gerizzim, in the Land of Israel. On the Top of Mount Ebal there stood the Six of the Israelitish Tribes and Six on the Top of Mount Gerizzim. Certain Levites with the Ark of God, in the Valley between them, directing themselves unto Mount Ebal with a Loud Voice, uttered very Distinctly, no less than Twelve terrible Curses, unto which the Tribes on that Mount, made the very Heavens ring, with a dreadful, Amen, unto them.

But between each of these Curses, the Levites directed themselves unto Mount Gerizzim, with Blessings directly opposed unto those Curses; and the Tribes on that Mount, gave the Shout of a Joyful, Amen, upon them.

'Tis true, the Order prescribing the Blessings, is not so distinctly Recited by Moses, as that of the Curses; because 'tis Reserved as the Special Glory of our Blessed Lord Jesus Christ, and of His Glorious Gospel, to bring in the Blessings of Obedience.

Until the Gospel of the Lord Jesus Christ arrive unto us, the Law does pronounce unto us nothing but Curses, we hear nothing but a Thunder of Wrath Cursing of us. 
The Second of the Direful Curses, which the Levites of God, facing to Mount Ebal, pronounced was, Cursed be he that sets Light by his Father or his Mother.

Doubtless, when the vast Body of people, as one man, replied, Amen, upon it, it sounded like an horrible Thunder-clap. Yea, but the Thunder-clap is not yet over; the peals of it, are this very Day to be again Sounded, in the midst of you, O Congregation of God.

We read, that when the thing thus Appointed, was first observed by the Tribes of Israel, in the Days of Joshua, [Joshua 8:35]. There were the Little Ones, in the Congregation. It is not amiss, that there are so many Little Ones in the Great Congregation here come together; and unto Them especially, am I now to bring that Warning from God.

The heavy Curse of God, Will fall upon those Children, That make Light of their Parents.

To Set Light by one's Parents, is in other words, to Treat them with any Ungodly Contempt: And, you mind it, My Children, that the Curse of God is denounced, not only upon Children, which cast Contempt upon their Fathers:

Oftentimes the Fathers have the Wisdom to keep up their Authority, and keep themselves above the Contempt of their Children.

But the Mothers do more frequently by their Fondness, and Weakness, bring upon themselves, the Contempt of their Children, and Lay themselves Low, by many Impertinencies.

Now, behold, the Admonition of Heaven; the Children which cast Contempt upon their Mothers do also bring themselves under the Curse of God.

The Curse of God! The Terriblest Thing that ever was heard of; The First born of Terribles! Can't I mention this Tremendous Thing, The Curse of God; and, Oh, My Children, Will not you Tremble at it?

Who can forbear crying out, as Elihu did, when he heard the Thunders of God railing in the Heavens over him, At this my heart even Trembles, and it is moved out of its place! I hope, none of you are come to such a Degree of Atheism, as to Defy, the Curse of God: You won't mock at the Fear of the most Fearful Thing, in the World.

But give me your Attention, while I do from the Oracles of the Almighty God, handle that CASE among you.

C A S E

What Respect, to their Parents must be rendered by the Children, that would not by Affronts to their Parents, bring down upon themselves the dreadful Curses of God?

The Lessons, which I have now to Set you, My Children, be these.

1) Maintain in your own Spirits, a Dread of those Dreadful Curses, with which the God of Heaven uses to take Vengeance on the Children, who put not Respect, but Contempt, upon their Parents. Beyond, how dreadfully the Judgments of God follow the Children that Set Light by their parents; and Oh, my Warned Children, upon the sight of those Warnings, cry out, Lord, my Flesh trembles for fear, and I am afraid of those Judgments!

Indeed there is no Sin more usually Revenged, with the Sensible and Notable Curses of God, than that Sin, The Contempt of Parents.

Exasperated Parents themselves, do sometimes Imprecate Curses upon their Children; and the Invisible World with a strange, but a quick work, usually says, Amen, to those Curses.

But, I beseech of you, O Parents, that be your Exasperations What they will, you forbear to use any Imprecations on your Children. Alas, They will be Cursed Children fast enough, without the least ill wish of yours to hasten it.

When it was Instituted, that the Levites were to proclaim, Cursed is he that sets Light by his Father, or his Mother, One part of the Institution was, All the people shall say, Amen. Truly, it often comes to pass, that when the Curses of God come upon them that set Light by their Parents, it shall be so, that all the people shall take Notice of it; all the people shall see an Amen, set unto it, shall see it Ratified. Children, I must be a little particular with you.

First. Undutiful Children, for the Sin of the Contempt they cast upon their Parents, are often Cursed by God, with being Left unto yet more Sin against Him. I could not have spoken a more Terrible word! This is most certain, The more Sinful any man is, the more Cursed is that man. It is an amazing Vengeance of God, that gives a Sinner up to Sin for Sin, and Curses a Sinner for one Sin, by Leaving him to another. 
But Undutiful Children, are commonly Cursed, and Banned by such a Vengeance of God. We read of some Sinners, whom the Justice of God gives up to Sin, and this is one Brand upon those doleful Sinners, in Rom. 1:30: Disobedient unto Parents.

The Fifth Commandment stands in the Front of all Six, upon the Second Table of the Law. Children, If you break the Fifth Commandment, there is not much Likelihood, that you will keep the rest; No, there is Hazard, that the Curse of God, will give you up to break every one of them all.

Undutiful Children soon become horrid Creatures, for Unchastity, for Dishonesty, for Lying, and all manner of Abominations: And the Contempt which they cast upon the Advice of their Parents, is one thing that pulls down this Curse of God upon them.

They who sin against their Parents, are sometimes by God given up to Sin against all the world beside. Mind the Most Scandalous Instances of Wickedness and Villainy; You'll ordinarily find, they were first Undutiful Children, before they fell into the rest of their atrocious Wickedness.

Secondly, Undutiful Children for the Contempt they cast upon their Parents are often Cursed by God, with a Mischief brought upon all their Affairs. A Strange Disaster uses to follow Undutiful Children, much Evil pursues that kind of Sinner; there is a secret Vengeance of God, perplexing their Affairs; through that Vengeance of God, None of their Affairs do prosper with them.

When David was vexed with one of his Undutiful Children, he could foretell, in Psal. 55:19. God shall Afflict them. There is a Secret Blast of God, upon Undutiful Children.

They are Afflicted in their Estates: It is the Curse of God upon them, for their being Loathe, to do what they could for their Parents, with their Estates.

They are Afflicted in their Bodies: It is the Curse of God upon them, for their Dishonouring the Parents of their Bodies.

God Afflicts them with Reproaches: 'Tis the Curse of God upon them; they have Reproached or Despised their Parents.

They are followed with one plague after another, by the Irresistible Wrath, and Curse of God: they can't comprehend, how they come to be so plagued in all their Interests: 'Tis it may be their Contempt of their Parents, that has been the Worm at the Root, which causes all to wither with 'em. And if these Undutiful Children, ever Live to have Children of their own, God pays 'em home in their own Coin; God pays 'em in the Undutifulness of their own Children, in the Undutifulness of their own Children, God makes 'em to possess the Iniquities of their Youth.

Judah, cast Contempt upon his Parents, by Marrying a Canaanitess, as it should seem without their Consent: God Cursed this Judah with a couple of Children who were such Wretches, that the Immediate Hand of Heaven, dispatch'd 'em out of the World.

You have doubtless been inform'd of that famous History, in the Theatrum Historie; A vile Son did once beat his old Father, and then Drag him to the Threshold of the House, by the Hair of the Head. Afterwards, when he grew Old himself, (which by the way, was a Rare Thing!) his own Son did in like manner beat him, and then Drag him also, by the Hair of the Head, not only to the Threshold, but out of the Doors, into the Dirt. Hereupon he cried out with Anguish, Ah! If this Varlet had pulled me only to the Threshold, I had been served, but just as my Father was by me! Children, Remember this.

Thirdly, Death; Yea, an Early Death, and a Woeful Death, is not seldom the Curse of God upon Undutiful Children for their being so. It is the Tenour of the Precept, Honour thy Father and thy Mother, that thy Days may be long upon the Land. Mind it, Children; Your Days are not like to be long upon the Land, if you Set Light by your Father or Mother.

When Absalom, with his Crue, was manifesting a Bloody Undutifulness, his offended Father predicted thus much, That those bloody and crafty men, should not Live out half their Days. Why, he knew, that the very Finger of God, had once written as much as this comes to; That Children, which did not Honour their Parents, must not look to have their Days long in the Land.

We have all heard the Fate of that Undutiful Absalom; now some Travellers Report that in the place where Absalom was Buried, there is now a vast Heap of Stones, thus produced: It is customary for them, that go by the place, to throw a Stone upon it, using these words;

Thus it shall be done unto the Son that Rebelleth against his Father.

Stand still, O my Children and Look with Horror upon the Grave of Absalom: Read there, and see the 
Curse of God upon the Undutiful.

Children that cast Contempt on the Parents, who have been the Instruments of their Life, do thereby, what, but make Forfeitures of their Life?

It becomes Children to reckon it one main Design, and Business, and privilege of their Life, to be Comforts unto their Parents: When they cease to do so, God with a direful Curse often gives that Order about them, Take away the Life of that Undutiful Creature! That Creature shall no longer Live in the World. It was an Edict of Heaven, in Exod. 21:17. He that curseth his Father or his Mother, shall surely be put unto Death.

And what shall then be done unto the Children, that prove Curses unto their Father, or their Mother? Undutiful Children are so; But the Curse of God puts them to Death for it: And because those Undutiful Children are Wicked over much, therefore they Die before their Time.

Yea, 'tis no unusual Thing for the Death of Undutiful Children, to be Embittered with some Extraordinary Circumstances of Confusion and Calamity. I tell you, O Undutiful Children; There is Danger, Lest you be so Cursed of God, as to be Hanged on a Tree, at the Last.

It is Remarkable, That the Most of them, who are Executed on the Gallows, do at their Execution cry out of This: Oh, 'Tis my Undutifulness unto my Parents, 'Tis my Disobedience unto my Parents, that hath brought me unto this Lamentable End!

It is a memorable passage, in Prov. 30:17: The Eye that mocks at his Father, and despises to obey his Mother, the Ravens of the Valley shall pick it out, and the young Eagles shall Eat it. It seems, an Untimely and a Tragical Death, often Exposes the Carcasses of those Children, to the Carnivorous Fowls of Heaven.

There was a Law in Israel, Deut. 21:21: That the Rebellious Child should be put to Death. After Stoning, he was Hang'd up; for in Israel they Hang'd up none, till they had first otherwise kill'd him; and no doubt, his Corpse being taken down, as it was to be done before Sunset, it was thrown into a Noted Pit, such an one as that, into which they threw the Corpse of Judas over the Precipice; and there the Fowls of Heaven prey'd upon it. Agur perhaps alludes to This; And we often see it so, that the Rebellious Child, is left of God, unto those Crimes, for which he is put to Death, e're it be long.

More than so; Undutiful Children are Unnatural Children; And the Curse of God sometimes gives over Unnatural Children to commit the most Unnatural Murders. They have Murdered themselves, and been Self-Destroyers: As they have Sinn'd against Nature, so they Die the most against Nature, that can be.

A Young man in this Country Drown'd himself; but he Left behind him a Writing to his Father, wherein he complain'd, O Father, I have kept my Soul, as long as I could; My Ruin was the pride and stubbornness of my Tender Years!

But is this all? No; Lastly; All the Curse of God upon Undutiful Children hitherto, is but the Death, riding the Pale Horse in the Revelation; whereof 'tis said, Hell followed. I am after all to tell you, That the Vengeance of Eternal Fire, will be the portion of Undutiful Children after all; Children that cast Contempt upon their Parents, God will cast into the Vengeance of Eternal Fire at the Last, and into Everlasting Contempt.

Surely, the Damned, are the Cursed of God! Hear, O Children; If you are the Children of Rebellion, the Curse of God will make you the Children of Perdition, throughout Eternal Ages.

Undutiful Children, what are they, but the Children of Belial? This is as much as to say, they are the Children of Satan; and unto Satan they shall go. The Bible has call'd 'em, The Children of the Devil; And whither shall the Children of the Devil go, but into the Everlasting Fire, prepared for the Devil and his Angels? The Fiends of Darkness, will be the Ravens, and the Eagles, that shall fasten their Talons, in the Eyes of those Children.

When our Lord Jesus Christ, the Judge of the World, foretells, that in the Day of Judgment, having said unto those on His Right Hand, Come ye Blessed, He will say unto those on His Left Hand, Depart, ye Cursed, into Everlasting Fire, with the Devil and his Angels; He seems to allude unto the action between Gerizzim and Ebal. Truly, the Children Damn'd of old, upon Mount Ebal, for Setting Light by their Father or their Mother, will be They, whom the Lord Jesus Christ, will one Day Doom, to Depart from Him into Everlasting Fire, with the Devil and his Angels. It was said, in Prov. 20:20 - Whoso curseth his Father, or his Mother, his Lamp shall be put out in Obscure Darkness.

Children, If by Undutifulness to your Parents, you incur the Curse of God, it won't be Long before 
you go down into Obscure Darkness, even, into Utter Darkness: God has Reserv'd for you the Blackness of Darkness forever.

Be it known to you; that Undutifulness to your Parents, will bring you to feel many Stripes, from an Enrag'd Conscience in the World to come; for you know the Will of God; Your Undutifulness is a Sin against your Conscience.

Yea, be Dutiful to thy Parents, or expect all the formidable outpourings of an Infinite and Eternal Wrath upon they Soul.

Thou dost not value the Wrath of thy Parents; It is a Light Thing to thee: But the Wrath of the Lord God Omnipotent, Oh, Don't make Light of That; It is a fearful thing to fall into the Hands of the Living God!

I hope, we have been long enough upon Mount Ebal. Shall we now turn a little unto Mount Gerizzim?

II. Let the Signal Blessings of God, upon Children who treat their Parents with due Respect, find much Respect with you, be a great Encouragement unto you, have a strong Impression upon you.

The Levites, as far as we understand, were to turn unto Mount Gerizzim, and with a loud voice to say, Blessed be he, who doth not set Light by his Father, or his Mother: And all the people were to say, Amen.

Hearken, O my Children, to the Blessings of God, that shall be poured and showered from on High upon the Dutiful; and let them charm you, into all possible Dutifulness.

There are Children, whose continual Desire and Prayer it is, That they may be in all Things made Rich Blessings unto their Parents. They Honour their Parents, and are an Honour to their Parents. Their Parents do with Glad Hearts behold their Wisdom, and must bear this Testimony for them, Never were Parents more Happy in their Children.

O the Blessings that belong to Children of such a Character! If it might be said, as it was by David, when God gave the Temple of the Lord; in Psal. 127:5 Blessed is the man, that hath his Quiver full of such Arrows,; Then surely, Blessed are the Arrows, that are in the Quiver of such a man!

The Holy Spirit of God sets a special Remark, upon that Command, which requires Children to be Dutiful unto their Parents: in Eph. 6:2 - 'Tis the First Command [of the Second Table] with a promise, That it may be well with thee.

It shall be well with you, O ye Dutiful Children: you have the word of a God for it. You may note it, That in the Command, what we Translate, That thy Days may be Long, is to be read, That they may prolong thy Days.

Who are those They? They are they Father, and thy Mother. But how can thy Father, and thy Mother, prolong thy Days? How, but by Blessing of thee, in the Name of the Almighty God.

If the Days of such a Child be not prolong'd, we must allow a Sovereignty in such Dispensations of Heaven; but there is cause to hope, for such a Child, that God has prolong'd his Days, in the happiness of the Heavenly Word.

This is plain; Those Parents, that are Blessed with Dutiful Children, do with an inexpressible Agony wish all sorts of Blessings to their Children. If it were in their power, to confer Blessings upon their Children; Oh, how much would they do for them!

Now because, 'tis in the power of God alone to confer Blessings upon us, these Parents go to God, for their Children, and they say with good old Jacob, God Bless the Lads!

I assure you, such Benedictions from obliged Parents, have a more than ordinary Authority, and Efficacy in them. For one's Parents to go before God, and plead, Ah, Lord, such a Child of mine, has Loved me, and Served me, and Helped me; and his good Carriage is to me, has been such, that even upon that Account I have reason to wish him all the good in the world: I therefore bring that Child unto thee, and I pray thee to Bless him with all Blessings of Goodness: To be thus Blessed by one's Parents, O my Children, 'tis a thing of more value than if a rich Inheritance were to be received from them.

This is very certain, There is no point of Religion, more certainly and commonly Rewarded with Blessings in this world, than that of rendering unto Parents the Dues that pertain unto them. A signal Prosperity, even in this world, uses to attend those Children, that are very Obedient or Serviceable unto their Parents. Those Reckabites, that Obey the Commandment of their Father, Thus said the Lord of Hosts, They shall stand before me forever.

There are Children, who have with unspeakable pleasure, supported their Aged Parents, in their 
Necessities; They have said unto their Necessitous Parents, like Joseph, Thus saith thy Son, come down to me, Thou shalt be near to me!

I believe, There are some at this very Time, in this very place who can say, That from the Time, they did for their Parents as they have done, God hath signally Smiled upon them.

Friend, That Aged Father or Mother, in thy House, is not only the Glory of thy House, but a better and a richer Thing than a Mine of Silver there.

Children, Be Blessings to your Parents, and be Assured, That those Parents will be Greater Blessings to you, than you can be to Them. They will be so as Long as they Live; yea, more than so; After your Parents are Dead and Gone, the Effects of their Prayers will yet Live: All the Prayers which those Gratified Parents put up for you will be still Answering, after they are Dead, as long as you yourselves do Live.

David had been a Son, very Tender of his Parents: and now, says, David, in Ps. 27:10: When my Father and my Mother forsake me, then the Lord will take me up: He'll Requite all that I did for my Father, and my Mother.

Shall I go a step further? When you yourselves also are Dead and Gone, even Your Children may Reap the Fruits of what you did for your Parents: Your Posterity, may fare the better for your Dutifulness.

The Jews have a Notion among them; 'That for the sake of the Honour, that Esau paid unto his Father, the Israelites Long after might not Extirpate the Edomites, who were the Posterity of Esau. Moses tells the Israelites, You have compassed this Mountain Long Enough. Why? Because Esau compassed a Mountain in Hunting for his Father.

But after all; Dutiful Children acting upon principles of Christianity, may hope to meet with their Christian Parents in Heaven; There Abraham the Religious Father, Their Isaac the Dutiful Son, there Jacob the Dutiful Grandson, are Together; Blessed are they that meet there, in the Light of the face of God; Blessed throughout Eternal Ages! Consider This, O Children; and Set not Light by your Parents.

But being, by these Considerations prepared for it, it may now be Time to say;

III. The Respects that Children must render unto their Parents, are comprised in those Three Words, Reverence, and Obedience, and Recompence.

Children do Set Light by their Parents, or cast Contempt on them, if they withhold any of these Three Regards from them, and the Curse of God, will Revenge the Contempt.

First, You Set Light by your Parents, if you withhold from them, the Reverence that is due unto them.

The God of Nature hath placed a Distance, between Parents and their Children; Children then Set

Light by their Parents when they Forget this Distance.

There is first, and Inward Reverence, that Children owe unto their Parents.

It was Enjoined in Lev. 19:3: Ye shall Fear every man, his Mother and his Father. Children, you Set Light by your Parents, if your minds are not Struck, with some awful Apprehension of their Superiority over you; if you don't see an awful Image of God, in their Superiority; if you don't look upon them, as the very Deputies of God, in their several Families.

But this Reverence must have some Outward Expression given of it.

There is an Outward Reverence, that Children owe unto their Parents. Hence 'tis said, in Mal. 1:6: If I be a Father, where is my Honour? Hence 'tis said, in Prov. 31:28: Her Children Rise up, and call her Blessed.

Their Speeches, both to their Parents, and of their Parents, must be full of Reverence. When Children speak to their Parents, their Language must carry in it, some Acknowledgment of their being such.

Thus in Gen. 31:35: She said unto her Father, my Lord. When Children speak of their Parents, they must show a concern, that nothing Abusive be uttered. Thus, in Psal. 127:5: The Children of Youth, seem to Defend their Father, from the Enemies in the Gate, or, False-Accusers.

And their Actions towards their Parents must yet more Emphatically Speak the Reverence, which they would Retain for them. Thus is Gen. 48:12: Joseph bowed himself, with his Face to the Earth, before his Father. Thus in I Kings 2:10: Solomon Rose up to meet his Mother, and bowed himself unto her, and She Sat on his Right Hand.

Now, Children, you Set Light by your Parents, if you Talk Saucily and Clownishly unto them; If you Reproach them, defame them, and Backbite them; if your Behaviour towards them have any malapert Impudence in it. 
Though your Parents may give you never so much Occasion of Complaint, it becomes you to make as Little Reflection upon it, as ever you can. Say Nothing, but what the Glory of God makes it Necessary for you to say.

Though they should happen to do you any Injuries, you may not show those Resentments, that you have upon the Injuries of other Persons.

Secondly; You Set Light by your Parents if you withhold from them, the Obedience that is due unto them.

If Children don't Study to Do, what their Parents would have them to do; and if the Word and Will of their Parents have not the Force of a Law upon them, the Children do Set Light, by them, in such a misbehaviour.

It was demanded in Eph. 6:1: Children, Obey your Parents in the Lord, for this is Right. Children, you Set Light by your Parents, if you don't count it a Right, a Just, a Fair Thing, and a Thing very Reasonable, for you to be the Servants of them, who have done so much for you their Children, and beware of Crossing them, who have done so much to Comfort you.

It was said, in Col. 3:20: Children, Obey your Parents in all Things, for this is well-pleasing unto the Lord. But, Children, You Set Light by your Parents, if it be not also very Well-pleasing unto You, to Please them, so far as without Sin you may do it; and if you be not unwilling at any Time, to give them any Displeasure.

When the Father of Joseph laid his commands upon him, he obey'd those commands, though with the Risk of his very Life. It should be the very Joy of your Life, to yield Obedience unto the commands of your Parents.

Do your Parents give you any Instruction? You are call'd upon, in Prov. 4:1: Hear, ye Children, the Instruction of a Father." Most of all, in the Grand Motions \& Changes of your Life, Children, your Parents are to be consulted, and the Satisfaction of your Parents is to be proposed.

In your Callings, and in your Matches especially the Directions of your Parents must be of Exceeding Moment with you; Indeed Nothing should be done without them! Wherefore, Children, you Set Light by your Parents, if you make nothing of their Commands, and if you tread their just Reproofs under foot.

You Set Light by them, if you Leave Undone what they Desire, and much more, if you Do what they Forbid.

You Set Light by them, if their Anger, be a Light matter with you.

Thirdly, You Set Light by your Parents, if you withhold from them the Recompence that is due unto them.

Those Children Evidently Set Light by their Parents, who are Insensible of the Obligations which their Parents have laid upon them, or, who count any thing too much to be done by Children for their Parents.

Of Joseph 'tis said, in Gen. 47:12: He Nourished his Father, and all his Father's Household with Bread. And it is elsewhere pressed upon us, Despise not they Mother, when she is old. Children, you Set Light by your Parents, if you don't Requite them as well as you can, and if you imagine that you ever can Requite them Enough. It was a Sad saying of Luther's, That One Father will more willingly maintain Ten Sons, than Ten Sons will maintain One Father. But those Children do Set Light by their Parents, who had not as liev [willingly, gladly, freely] maintain their Father, as maintain their Children; and who would not gladly be to their Mother, the Restorer of her Life, and the Nourisher of her old Age, as the Mother of Ruth, found her Son-in-Law to be unto her.

It was demanded, in I Tim. 5:4: Let the Children Learn to show piety at home, and requite their Parents; for that is Good and Acceptable before God. Those Children have no Piety in them, they Set Light by God, as well as by their Parents, unto whom it is not a most Acceptable Thing to make some Recompence unto their Parents, for all the vast Benefits which their Parents have heaped upon them.

Children, Do you think, you can ever make a Recompence unto them, that have Born you, and Bred you, and Fed you, and Endured Thousands of Sorrows for you.

One says, 'Many treat their Parents, as they do their Candles: they Set them in High Candle sticks while they are full of Tallow, but when all their Substance is wasted, they tread them underfoot. And some there are, who do not Support their Parents, but Wrong them, and Rob them, and Pillage them. They Waste 
their Parents.

Alas, Children, you Set Light by your Parents in all of this Impiety. But, Oh, don't make Light of this Impiety; Say, Destruction from God is a Terror to me!

IV. By Father and Mother, All sorts of Parents are intended;

Let the Caution be accordingly Extended, and Set Light by no sorts of Parents Whatsoever.

Natural Parents cannot safely come under the Contempt of their Children: God will Curse the Children that Set Light by Them; and can you dream then, that God will allow any Contempt of Political Parents, of Ecclesiastical, or of Scholastical?

There are Parents in the Commonwealth, as well as in the Family;

There are Parents in the Church, and Parents in the School, as well as in the Commonwealth. If you Set Light by these Parents, you Herd yourselves among the Cursed of God.

Remember, O Servants, thy Master, is thy Father, and thy Mistress, is thy Mother. Do not Set Light by thy Master, or thy Mistress, Lest the Curse of God at last hang thee up in Chains, among the Monuments of His Indignation.

Because thy Superiours in the Family, are thy Parents, therefore there is laid that Charge of God upon thee in 1 Pet 2:18: Servants, be subject unto your Masters, with all Fear, not only to the Good and Gentle, but also to the Froward.

The Proud hearts of many Servants, make them discontent at their Servile State. The Subjection expected from them throws them into a very crumbling Discontent.

Ye proud Wretches, your Sin, was the very Sin that at first made all the Devils in Hell. The Devils, those proud Spirits could not bear to be Servants in such a Station as God had ordered for them; and for this their Pride, The Almighty has Cursed them, and Damned them.

Servants, have a care, Lest by your Pride you fall into the Condemnation of the Devil. It is the Providence and the Ordinance of the Lord Jesus Christ that hath made you Servants; and if out of Regard unto Him, you carry it well in your Servitude, He will graciously Accept all that you do, as if done unto Himself.

It was therefore said, in Col. 3:23, 24: Servants, whatever ye do, do it heartily as unto the Lord, and not unto men; knowing that of the Lord you shall Receive the Reward of the Inheritance, [which belongs unto Sons] for ye Serve the Lord Christ. Well then, Don't Set Light by your Masters. If they be Masters, where is your Fear of them?

Expose not their Failings, if you see any in them. Let there be no Sullenness, no Sauciness, no Rude Retortings, in your Deportments towards them. Give them no cause to complain, with Job, I called my Servant, and he gave me no Answer.

Be not those Eye Servants, that will do their Master's will, no longer than their Master's Eye is upon them; The All-seeing eye of the Almighty God is upon you.

Transgress not their just Commands, either Wilfully, or Carelessly; If you do, the Commands of God are also Transgressed in your Miscarriages.

Indeed, if your Masters bid you do an ill Thing, you must with modest Expostulations, rather Suffer than Obey. But if they bid you do what is Fit and Right, you Sin against God, if you do it not; If they will not obey you, Masters, Turn them out of Doors.

Nor is this all that Servants have to do: Servants, you must use all Diligence, and Faithfulness, in your Master's Business. A Slothful Servant is truly called a Wicked Servant.

But Eleazer, the Servant of Abraham, would not Eat his Victuals, till his Masters Business were dispatched. Let your Master's Business be honestly discharged, though you should like Jacob, when a Servant, have your Sleep departing from your Eyes.

When your Masters do send you on Errands, Loiter not; Be not Sluggards to them that feed you.

And be the true Sons of Israel; able to say, Thy Servants are True men. Gehazi was a Servant that Lied unto his Master; but God made that Liar to become a Leper. Of all Faults in your Servants, I advise you, Masters, never to let that of Lying be unpunished.

But that of Stealing often accompanies it; of which, O Servants, beware; for God will never let That go unpunished. I vehemently call upon you, That you never venture to wrong your Masters unto the value of a Penny as long as you Live. Mark it, you'll Entail Eternal Vexations upon you, and God will make you 
lose a Pound for every penny, whereof you have wrong'd your Masters.

Have you ever purloined from them? Oh, Fly penitently unto the Blood of the Lord Jesus Christ for pardon, and make as much Restitution, and as full Reparation, as ever thou canst; or the Jealous God, will never pardon thee, till the Torments of the Damned, have Exacted the utmost Farthing from thee.

Servant, Be such a Blessing in thy Master's House, as Joseph was to his. Contrive all the ways imaginable, that thy Master may be the better for thee. It may be, thy Master will Bless God for Thee. However God will Bless thee in thy Serving of him. If you slight all these Things, Look for the Curses of God. And now, Let people Remember, That Rulers are Parents. Don't Set Light by Them. The Charge of God upon people, is That in Tit. 3:1: Be Subject, and Obey Magistrates, and be ready to every Good Work, and speak evil of no man; much less of the Magistrates.

Our Setting Light by Excellent Magistrates, has been the Scandalous Crime of our Country; and for that Crime whole Colonies may come to smart under the Revenges of God.

Let Churches Remember, That Pastors are Parents. Don't Set Light by Them. The Charge of God upon Churches, is That in Heb. 13:17: Obey them that have the Rule over you, and submit yourselves; for they watch for your Souls, as they that must give Account, that they may do it with Joy, and not with Grief; for that is unprofitable for you.

There hath been a Disorder, called, Corahism, sometimes very Extravagant. But for Setting Light by Ministers, that have been Holy, and Able, and Faithful, and Painful Men of God, God sometimes removes a Candlestick out of its place, or at least says, Never shall a Burning and a Shining Light more be seen standing in it.

Let Scholars regard their Tutors as their Parents. My Child, The Master of the School is a Father to thee. Those that were under the Education of Moses, are called, The Sons of Moses.

Wherefore, Scholars, Do you with all Conscience of God, Honour your Tutors; and perform the Tasks which they Impose upon you. Don't Set Light by thy School-Master; but Love him, and Prize him, and Hearken to him, and be Thankful to him, and Thankful to God for him. These are ways to Escape the Curses of God.

V. They that have at any Time Set Light by their Parents, must Go to God in Christ for His Pardons , that so His Curses may not overtake them.

Who is there that can say with the Son in the Gospel: who said unto his Father, Lo, these many years do I Serve thee, neither transgressed I at any Time thy Commandment? The Dutifullest Child among us all, hath been so Defective in his Dutifulness, that he dare not plead it before God, in his Justification; He must say, as in Psal. 143:2: Lord, Enter not into Judgment with thy Servant; for in Thy sight shall no man Living be Justified.

What then shall we do? Why, we read concerning Mount Ebal, where the Curses of God were Fulminated in Deut. 27:5,6,7: It was commanded, In Mount Ebal, thou shalt Build an Altar unto the Lord thy God, and thou shalt offer Burnt Offerings thereon unto the Lord thy God, and thou shalt Offer PeaceOfferings, and Rejoice before the Lord thy God. And we find that Joshua, afterwards did accordingly.

It is an Ingenious Note of one upon it: This was no more than Needed, for the Maledictions had no sooner been uttered, but Condemnation and Execution had instantly Ensued, if these Sacrifices with the Merit of Christ therein Typified had not seasonably interceded.

Children, you hear the Convex of Heaven resounding from Ebal with the Comminations of God, Cursed is he that Sets Light by his Father or his Mother.

Our Consciences tell us, That we have done it many a time. Away then, Away to the Antitype of the Altar on Ebal. Oh, plead with God the Burnt Offering of Christ, and the Peace-offering of Christ, that the Curse of God may not seize upon us, that we may not be Burnt in the Flames of His Indignation, that He may be at Peace with us forever.

When it was denounced Cursed is he that Sets Light by his Father or his Mother, it follow'd, that all the people said, Amen. AMEN, is the very Name of Christ. May all the people now fly to that, AMEN,, that they may be sheltered from the Curses of God.

And, Oh, call it to mind the Example of the Lord Jesus Christ. There never was in the world, so Dutiful a Son as He! We read in Lu. 2:51: He went down with His Mother, and His Reputed Father, and though they were very Low in the World, He became subject unto them. We read in Jn.19:17: 
That when He was in His Last Agonies, it was a Thing lying very near His Heart, that His WidowMother, might be provided for: He said unto a Disciple, Behold, thy Mother! Intimating that He would have him, take her Home unto his own House.

Now, be your Dutifulness to your Parents, never so complete, Let this Righteousness of the Lord Jesus Christ, be all that you will plead with God, as your Title to the promised Blessings of the Dutiful.

VI. Do not Go on, Children, If you value your Lives, and Souls, do not Go on to: Grieve your Parents, by any Disrespect unto their Admonitions, or by any Vanity whatsoever.

You cannot more Make Light of your Parents, than when you Make Light of their Counsels: Your Contempt of their Counsels, will speedily bring down God's Curses upon you.

Moses did well, when he Hearkened unto the voice of his Father-in-law, and did all that he had said. It is the voice of Heaven, in Prov. 1:8: My Son, Hear the Instruction of thy Father, and forsake not the Law of thy Mother.

Is it not the Instruction of thy Father, That thou shouldest avoid all Vicious Company; and, That thou shouldest Pray in Secret every Day; and, That thou should Read and Hear the Word of God, with Assiduity [diligence, zeal, constancy]? Or if not so, yet it may be, the Law of thy Mother, who is in Travailing pains for thee, to see Christ formed in thee.

Now, don't Make Light of the Admonitions, with which thy Parents are thus calling upon thee. If thy Parents Enjoin upon thee any thing that is not Sinful, it will be a Sin for thee to Refuse the doing of it: How much more is the Sin, if thou dost Refuse to do what the Great God has first Commanded, and thy Parents Enjoin because the Great God has first Commanded?

Oh, my Children, I am afraid, I am afraid, there are some of you, that may read your Doom, in those Ominous words, in I Sam. 2:25: They hearkened not unto the voice of their Father, because the Lord would slay them.

It is an unutterable Grief that some of you give unto your pious Parents; They see, that you are still poor, carnal, and thoughtless Creatures: and that perhaps a piece of gay Attire, is of more Account with you, than a Christ, or a Soul.

'Tis told them, That the Ungodly Youths in the Town do horribly poison one another. These youths cry up an Indifferency in Religion, and say, 'Tis out of fashion for a man to be of one Religion more than another; that is, in reality to say, 'Tis out of fashion to be of any Religion at all. So they insensibly draw one another on, to deride Seriousness in Religion, and the most Serious and Lively Preachers of it; Until they become Idle, Profane, Sottish Debauchees, and betimes Ripe for the Fiery Indignation of God.

Your Parents are Trembling, with an unknown Distress and Anguish, Lest you be Entangled in a Familiarity with these Ungodly Youths. It fills your Parents with a grievous Horror, That they cannot see the marks of a Regenerate Soul upon you; They never hear you let fall a word, that may discover in you the least care of a Never-dying Soul. They cannot find out that there are any Transactions between the Lord Jesus and you, about the Salvation of a Soul in the Hands of the Destroyer.

As Austin (Augustine) says, of his Blessed Mother, Toties Fiolios parturiebat, quoties a Deo eos deviare cernebat, so it may be said perhaps of thine, She never sees thee Sinning against God, but it brings the Anguish of a New Travail upon her.

It may be, you once had some Good Beginnings, in Religion; Your Parents felt their Hearts within them Leap for Joy, at those Beginnings; They Hoped Well, This my Child was Lost, but is found; was dead, but is alive! But seeing all your Goodness gone, like the Morning Cloud, and the Early Dew, it throws them into an Extreme Consternation.

How Cheerfully would they give all they have in the world, if they might say of you, Behold, they pray! They are every Day Extremely uneasy, lest you Die before you are New born, and it had been Good for you, that you never had been Born at all.

Ah, Vain Children; Give, Give some Relief to this Grief of your Parents. Fall down before the Lord, and say, Lord, Thou shalt be my Father, and the Guide of my Youth. Turn to God in Christ, and become Devout Children. Then, say they, My Heart, O my Children, shall Rejoice, even mine!

But your Parents count that you make Light of them, so long as you Lightly Esteem the Rock of your Salvation, and make Light of God, and Christ, and the Covenant of Grace.

And now, I Earnestly testify unto you, That if you Go on, to Sin against God, and against your 
Parents, the Curses of the great God are impending over you. Those Curses will horribly Wound the Head of those that go on still in their Trespasses.

Yea, though you are the children of Pious Parents, the Advantage you might have had by that, shall be changed into a Misery. The more Pious Parents you have had, the more Forlorn Children shall you be throughout Eternal Ages.

We read that even the Children of Abraham themselves, will be Cast into the Fire of the Wrath of God, if they do not bring forth Good Fruit before Him; And we read of such among the Damned, as Cry out, Oh! Father Abraham, I am Tormented in this Flame!

It is a Strange passage, that I find lately published. The famous Dr. Twiss had been a very wicked Boy. There died a School fellow of his, that was more wicked than he. The Ghost of the Dead Lad, appeared unto Twiss, and horribly Cried out, I am Damned! This was, as his worthy son assures us, the occasion of Twiss' Conversion unto God.

Oh Tis to be Feared, That many of our Young People, who have died at home and abroad, and after the Madness of that Ungodly Life, by which they broke the Hearts of their Parents, are Gone unto the Dead; if they could in Ghost now appear unto their Fellow-Sinners, yet Surviving, they would horribly Cry out, I am Damned! I am Damned, for my Ungodliness!

But you have Enough to Warn you, against all Ungodliness, without One Coming to you from the Dead. And while we thus Warn you, there is this terrible Intimation to be added unto all the rest.

Refractory Child; Thy Pious Parents, themselves will not own thee, in the Day when God shall Curse thee, and cut thee off, and cast thee out forever. And all the Grief which thy Pious Parents here Endured for thee, and from thee, will be Oil to the Everlasting Flames of that Grief, which thou shalt Endure in the Place of Dragons.

Oh, come to a Right Mind, Thou Prodigal; and by Repentance give unto thy Pious Parents cause to say, This is a dear Son, and a pleasant Child. Then the God of Heaven Himself will Bless thee, and say, I will Surely have Mercy upon them. 


\section{Southern Sermon}

\section{Source: http://www.ruhr-uni-bochum.de/gna/Bacons_Sermon.rtf}

\section{Thomas Bacon's Sermon to Negro Slaves, 1743}

Knowing, that whatsoever good thing any man doeth, the same shall he receive of the Lord, whether he be bond or free.

My well-beloved Black Brethren and Sisters,

When you were last here, I endeavoured to shew you, That God made you and all the world, and that he made you and all mankind to serve him; That it is he who places every man in the station or rank which he holds in the world, making some kings, some masters and mistresses, some tradesmen and working people, and others servants and slaves. That every one of us is obliged to do the business he hath set us about, in that state or condition of life to which he hath been pleased to call us: And that whoever is doing his business quietly and honestly in world, and living as a christian ought to do, is serving of God, though his condition be ever so low and mean; and will be as much taken notice of, and as highly favoured by God at the last day, as the greatest prince upon earth, for God is no respecter of persons. I also laid before you, that you ought to serve God for your own sakes, because you have souls to be saved, and if you should lose them, you are undone for ever: That every one who dies, and goes into another world, must go either to heaven or hell; and that there is no other way of escaping everlasting punishment in hell, or being eternally happy in heaven, but by serving God while he spares our life upon earth.

I then went on to shew you, what duty you owe to God in particular, that you ought to look upon him as your great and chief master, to whom you must one day answer for every thing you have done in this life: That he is always looking upon you, and taking notice of your behaviour, so that if you could deceive all the world, you cannot deceive God: That you ought to love God above all things, or else he will not love you, which would be the most dreadful thing that could happen to you: That if you love God sincerely, you will be afraid of doing any thing that is bad, because his holy spirit is grieved to see men destroy their souls by their wickedness: That if the love of God is not strong enough to keep you from doing what is bad, and vexing and offending him thereby, you ought, at least, to dread his terrible judgments; for that he is able, not only to destroy your bodies, and strike you dead in a moment, but also to cast both body and soul into hell, which will certainly be the portion of all such, as provoke him to anger by leading wicked lives: That you ought to worship God both in publick and in private: in publick, by coming to church as often as you have leave and opportunity; and in private, by praying to him for every thing you want, and giving him thanks for all his goodness to you, which you may easily do, when you are walking, or working, in the house, or in the field: That you ought to reverence and honour Almighty God, and keep from all cursing and swearing, or making any light, foolish, vain use of his great and holy name: And that you must keep from all lying, because God hates all such as tell lies, and will give them over to the devil, who is the father of all lies and liars.

In the next place I endeavoured to shew you, how you ought to behave towards your masters and mistresses; and to make it plain to you, that as God himself hath set them over you here in the 
nature of his stewards or overseers, he expects you will do every thing for them, as you do for himself: That you must be obedient and subject to them in all things, and do whatever they order you to do, unless it should be some wicked thing which you know that God hath forbidden, in which case you are to refuse, but in no other: That you must not be eyeservants, that is, such as will be very busy in their masters presence, but very idle when their backs are turned: For your head master, Almighty God, is looking on you, and though you may escape being found out, or punished by your owners for it, yet you cannot deceive God, who will punish you severely in the next world for your deceitful dealing in this: That you must be faithful and honest to your masters and mistresses, not wasting their substance, or letting any thing, belonging to them, perish for want of your care; because that is next to stealing - for the master's loss is the same as if he had been robbed of it: And that you are to serve your owners with cheerfulness, respect, and humility, not grumbling, or giving any saucy answers, but doing your work with readiness, mildness, and good nature; because your sauciness and grumbling is not so much against your owners, as it is against God himself, who hath placed you in that service, and expects you will do the business of it as he hath commanded you. ...

Now, to suit this rule to your particular circumstances; Suppose you were masters and mistresses, and had servants under you, would you not desire that your servants should do their business faithfully and honestly, as well when your back was turned, as while you were looking over them? Would you not expect that they should take notice of what you said to them? That they should behave themselves with respect towards you and yours, and be as careful of every thing belonging to you as you would be yourselves? You are servants, do therefore as you would wish to be done by, and you will both be good servants to your masters, and good servants to God, who requires this of you, and will reward you well for it, if you do it for the sake of conscience in obedience to his command.

Again, suppose that you were people of some substance, and had something of your own in the world, would you not desire to keep what you had? And that no body should take it from you, without your own consent, or hurt any thing belonging to you? If, then, you love your neighbor as yourself, or would do by others as you could wish they would do by you, you will learn to be honest and just towards all mankind, as well as to your masters and mistresses, and not steal, or take away any thing from any one, without his knowledge or consent: You will be as careful not to hurt any thing belonging to a neighbour, or to do any harm to his goods, his cattle, or his plantation, or to see it done by others, as you would be to hurt yourself, or any thing you had of your own: And will behave yourselves towards all mankind with the same honesty and good will, as you could wish they would do to you in the like case.

Your fellow servants are more particularly to be looked upon as your brethren: Your common station, as slaves, your complexion, and your marriages one among another in different families, make you nearer to each other than all the rest of the world, except your owners. And, poor and ignorant as you are, you may do much good, and prevent much harm, by behaving one towards another as brothers and sisters ought to do, and as God requires of you. And, considering all things, you must be miserable creatures indeed, if you will not be loving and affectionate, kind and honest among yourselves. But for fear you should mistake my meaning, I will first describe to you, what true love and affection is, and then endeavour to shew you in particular, how you ought to behave one towards another. ... 
Suppose any of you to have been wicked creatures, idle, drunken, swearing, thievish, lewd people; and being at length overtaken by the hand of God, and laid down on a painful, sick bed, without any hopes of recovery, with all the terrors of conscience about you, and nothing before you but death, and the fearful apprehensions of being miserable for ever - what a dreadful state of mind must you then be in! And what would you then give, that you had been blessed with a true friend in your former days, one that had so much real love for you, as to have warned you of your danger, and have hindered you, by his kind advice, from running such lengths of wickedness as you had done? And would you not then think, that such a friend would have been of more value to you, than the whole world? You have it in your power to be such true friends and lovers one to another: And though you can give but little bodily help, you can do what is far better, you can help each other on in the way towards heaven. You can, nay, you ought to check one another, when you see any thing doing amiss: You can encourage each other in doing what is right and good: You can pray together, and you can pray for one another: You can, an a Sunday evening, talk about the good advice you have heard in Church, and by telling it to such as could not be there, may do them much good, and, at the same time, by thus repeating these things, they will be the stronger fixed in your own memory, so as to be of lasting service to yourselves: You can, by a good example, prevent a great deal of wickedness and indecency, in your meetings and conversations one among another: And where you find that your sober, friendly advice, will do no good with them, you may terrify your companions from doing bad things, by threatening to complain of them; and by such means as these you may help to save their souls, and get a blessing upon yourselves and families. But, Oh, my brethren! I am grieved to say it, you are so far from doing this that I fear many of you rather encourage and help one another on in wickedness, and go hand in hand towards destruction, rather than strive to assist one another in the way to heaven! ...

Quelle:

Rev. William Meade, ed.,

Sermons Addressed to Masters and Servants, and Published in the Year 1743, by the Rev. Thomas Bacon, Minister of the Protestant Episcopal Church in Maryland (Winchester, VA, 1813) 111-19 
APPENDIX J

COLONIAL CONCLUSION \& COMPARISON (DAY TEN)

Grading Rubric for Diary Entry 
Grading Rubric for Diary

\begin{tabular}{|c|c|c|c|}
\hline Day & Complete & $\begin{array}{c}\text { Some elements } \\
\text { missing }\end{array}$ & Incomplete \\
\hline 1 - Geography & & & \\
\hline 2 - Shelter & & & \\
\hline $3-$ Clothing & & & \\
\hline $4-$ Play & & & \\
\hline $5-$ Work (Age 1-7) & & & \\
\hline $6-$ Work (Age 7- & & & \\
\hline 7 - School & & & \\
\hline 8 - Church & & & \\
\hline 9 - Conclusion & & & \\
\hline $10-$ Comparison & & & \\
\hline
\end{tabular}




\section{BIBLIOGRAPHY}

Axtell, James L. The School upon a Hill: Education and Society in Colonial New England. New Haven and London: Yale University Press 1974.

Bushman, Richard L. From Puritan to Yankee: Character and the Social Order in Connecticut, 1690-1765. Cambridge, MA: Harvard University Press 1967.

Cable, Mary American Manners and Morals. New York: American Heritage Publishing Co., Inc., 1969.

Cable, Mary The Little Darlings: A History of Child Rearing in America. New York: Charles Scribner's Sons, 1975.

Carson, Jane Colonial Virginians at Play: A Colonial Williamsburg Research Series. Charlottesville: University of Virginia Press, 1965.

Daniels, Bruce Colin Puritans at Play:Leisure and Recreation in Colonial New England. New York: St. Martin’s Press 1995.

Demos, John A Little Commonwealth: Family Life in Plymouth Colony. New York: Oxford University Press, 1970.

Douglas, Norman London Street Games. London: Chatto and Windus 1931.

Earle, Alice Morse Child Life in Colonial Days. Stockbridge, Massachusetts: Berkshire House Publishers 1899.

Fiske, John The Dutch and Quaker Colonies in America: Two Volumes. Boston: Houghton-Mifflin Company 1899.

Graff, Harvey J. "Interdisciplinary Explorations in the History of Children, Adolescents, and Youth for the Past, Present and Future" The Journal of American History, Vol. 85, No. 4 (March 1999), 1538-1547.

Greven, Philip J. Four generations: population, land, and family in colonial Andover, Massachusetts. Ithaca, N.Y.: Cornell University Press, 1970. Viewed online at http://ets.umdl.umich.edu.ezproxy.humboldt.edu/cgi/t/text/textidx?c=acls;cc=acls;idno=heb01361.0001.001; view $=$ toc

Hawke, David Freeman Everyday Life in Early America. New York: Harper \& Row 1988. 
Hawke, David The Colonial Experience. Indianapolis: The Bobbs-Merrill Company, Inc. 1966.

Heyrman, Christine Leigh, The Church of England in Early America (Department of History, University of Delaware) Website viewed April 1, 2006 http://www.nhc.rtp.nc.us/tserve/eighteen/ekeyinfo/chureng.htm

Hole, Christina English Sports and Pastimes. London: B.T. Batsford Ltd. 1949.

Leonard, Eugenie Andruss and Sophie Hutchinson Drinker and Miriam Young Holden The American Woman in Colonial and Revolutionary Times, 1565-1800.

Philadelphia: University of Pennsylvania Press 1962.

Menard, Russell R. “Whatever Happened to Early American Population History?” The William and Mary Quarterly, $3^{\text {rd }}$ Ser., Vol. 50, No. 2, Early American History: Its Past and Future (April 1993), 356-366.

Mintz, Steven Huck's Raft: A History of American Childhood. Cambridge, MA: The Belknap Press of Harvard University 2004.

Nash, Gary B. and Julie Roy Jeffrey The American People: Creating a Nation and a Society, Brief Fourth Edition. New York: Longman Press 2003.

Pomfret, John Edwin, edited by Ray Allen Billington The Reinterpretation of Early American History. San Marino, CA: The Huntington Library 1966.

Reich, Jerome R. Colonial America, 5 ed. Upper Saddle River, NJ: Prentice Hall 2001.

Rothman, David J. “A Note on the Study of the Colonial Family" The William and Mary Quarterly, ${ }^{\text {rd }}$ Ser., Vol. 23, No. 4 (Oct., 1966), 627-634.

Smith, Daniel Blake "The Study of the Family in Early America: Trends, Problems, and Prospects” The William and Mary Quarterly, $3^{\text {rd }}$ Ser., Vol. 39, No. 1, The Family in Early American History and Culture (Jan. 1982): 3-28

Stanard, Mary Newton Colonial Virginia: Its People and Customs. Detroit: Singing Tree Press 1970.

Taylor, Dale The Writer's Guide to Everyday Life in Colonial America: From 16071783. Cincinnati: Writer's Digest Books, 1997.

Vinton, Iris The Folkways Omnibus of Children's Games. Harrisburg, PA: Stackpole Books, 1970. 
Wertenbaker, Thomas Jefferson The Founding of American Civilization: The Middle Colonies. New York: Charles Scribner's Sons, 1949.

Wright, Louis B. The Cultural Life of the American Colonies 1607 - 1763. New York: Harper \& Brothers Publishers 1957.

Youcha, Geraldine Minding the Children: Child Care in America from colonial times to the present. New York: Scribner 1995.

Web references:

http://www.newsday.com/community/guide/lihistory/ny-historyhs331a,0,7319850,print.story?coll=ny-lihistory-navigation Diary of Mary Cooper for the Day One Lesson Plan hook. Viewed on March 18, 2006

http://www.newsday.com/community/guide/lihistory/ny-historyhs301i87,0,6035399.photo Picture of the Mary Cooper Diary. Viewed on March 18, 2006

www.socialstudiesforkids.com/graphics/13mapnew.htm Information on each of the thirteen original colonies. Viewed on February 22, 2006.

www.milkpaint.com/articles Article from the New York Times about what milkpaint is and how it is made. The New York Times - March 25th 1993

Chocolate Milk? No, it's milk paint. By Terry Trucco. Viewed on March 19, 2006.

http://www.history.org/Almanack/life/food/foodhdr.cfm Colonial Food Article. Viewed February 23, 2006.

http://www.1771.org/cd_recipes.htm Colonial Food Recipes. Viewed February 23, 2006.

http://www.history.org/history/clothing/intro/index.cfm "Dressing the Part: An Interactive adventure”. Viewed December 22, 2005.

http://www.history.org/media/ Interactive website related to occupational trades. Viewed February 23, 2006.

http://www.nps.gov/fofr/col_kids.htm Sample diary entries of colonial children. Viewed February 23, 2006. 
http://www.eduplace.com/ss/maps/pdf/us1776.pdf Background map of the thirteen original colonies. Viewed December 22, 2005.

http://www.digitalhistory.uh.edu/historyonline/us3.cfm Demographic information for the colonies with student questions. Viewed on February 24, 2006.

http://www.plimoth.org/learn/education/kids/homeworkHelp/building.asp\#col Story about the arrival of the colonists. Viewed December 22, 2005.

http://members.aol.com/calebj/clothing.html Simple drawings of colonial clothing. Viewed February 24, 2006.

http://www.history.org/history/clothing/children/child01.cfm Picture of an engraving depicting colonial clothing. Viewed February 24, 2006.

http://www.jamestowne.org/Fashion.htm Southern colonial clothing. Viewed February 24, 2006.

http://www.plimoth.org/learn/education/kids/make.asp\#col Diagram and directions for playing Fox and Geese. Viewed December 22, 2005.

http://crossstitch.about.com/library/graphics/backstitch_alphabet.gif Cross stitch sampler alphabet. Viewed December 22, 2005.

http://pivot.mit.edu:8080/mfh/view-node.jsp?nid=32 Interactive website for colonial female choices for adult life. Viewed February 22, 2006.

http://www.history.org/Almanack/life/trades/tradehdr.cfm Apprenticeship Options for Boys. Viewed February 22, 2006.

http://hometown.aol.com/ntgen/hrtg/indenture.html Sample Indenture Agreement. Viewed February 22, 2006.

http://www.colonialhall.com/franklin/franklin.php The Story of Benjamin Franklin's Apprenticeship Experience. Viewed February 22, 2006.

http://www.iupui.edu/ engwft/hornbook.html Picture of a colonial hornbook. Viewed March 16, 2006.

http://www.spurgeon.org/ phil/mather/dut-chi.htm Cotton Mather Sermon. Viewed March 16, 2006. 
http://www.ruhr-uni-bochum.de/gna/Bacons_Sermon.rtf Thomas Bacon’s Sermon to Negro Slaves. Viewed March 16, 2006. 